OAK RIDGE NATIONAL LABORATORY

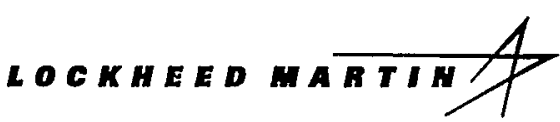

RECEIVED

APR 231999

OSTI

\section{Measurements of Mercury Released from Amalgams and Sulfide Compounds}

C. H. Mattus 
This report has been reproduced directly from the best available copy.

Available to DOE and DOE contractors from the Office of Scientific and Technical information, P.O. Box 62, Oak Ridge, TN 37831; prices available from (615) 576-8401. FTS 626-8401.

Available to the public from the National Technical Information Service, U.S. Department of Commerce, 5285 Port Royal Rd., Springfield, VA 22161.

This report was prepared as an account of work sponsored by an agency of the United States Government. Neither the United States Government nor any agency thereof, nor any of their employees, makes any warranty, express or implied. or assumes any legal liability or responsibility for the accuracy, completeness, or usefulness of any information, apparatus, product, or process disclosed, or represents that its use would not infringe privately owned rights. Reference herein to any specific commercial product, process, or service by trade name, trademark, manufacturer, or othenwise, does not necessarily constitute or imply its endorsement, recommendation, or favoring by the United States Govemment or any agency thereof. The views and opinions of authors expressed herein do not necessarily state or reflect those of the United States Government or any agency thereof. 


\section{DISCLAIMER}

Portions of this document may be illegible in electronic image products. Images are produced from the best available original document. 
Chemical Technology Division

\title{
MEASUREMENTS OF MERCURY RELEASED FROM AMALGAMS AND SULFIDE COMPOUNDS
}

\author{
C. H. Mattus \\ Date Published: April 1999 \\ Prepared for the \\ U.S. DEPARTMENT OF ENERGY \\ OFFICE OF TECHNOLOGY DEVELOPMENT \\ Washington, D.C. 20585 \\ Prepared by \\ OAK RIDGE NATIONAL LABORATORY \\ Oak Ridge, Tennessee 37831-6285 \\ managed by \\ LOCKHEED MARTIN ENERGY RESEARCH CORP. \\ for the \\ U.S. DEPARTMENT OF ENERGY \\ under contract DE-AC05-96OR22464
}




\section{CONTENTS}

LIST OF FIGURES $\ldots \ldots \ldots \ldots \ldots \ldots \ldots \ldots \ldots \ldots \ldots \ldots \ldots \ldots \ldots \ldots$

LIST OF TABLES $\ldots \ldots \ldots \ldots \ldots \ldots \ldots \ldots \ldots \ldots \ldots \ldots \ldots \ldots$ vii

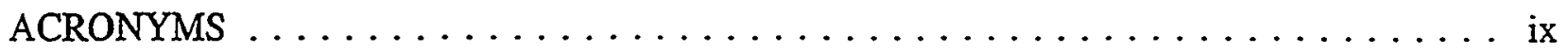

EXECUTIVE SUMMARY $\ldots \ldots \ldots \ldots \ldots \ldots \ldots \ldots \ldots \ldots \ldots \ldots \ldots \ldots$

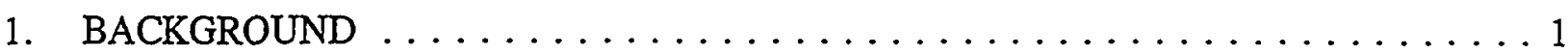

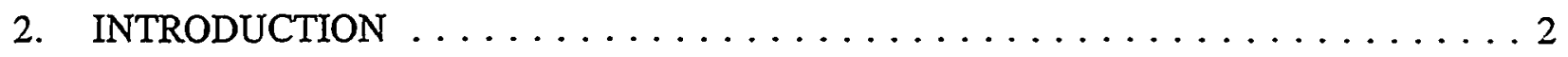

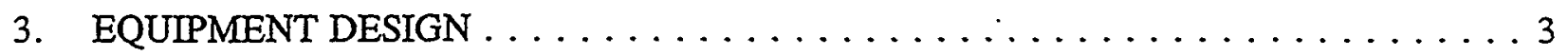

3.1 MERCURY VAPOR ANALYZER $\ldots \ldots \ldots \ldots \ldots \ldots \ldots \ldots \ldots \ldots$

3.2 COLD VAPOR ATOMIC ABSORPTION $\ldots \ldots \ldots \ldots \ldots \ldots \ldots \ldots$

3.3 INDUCTIVELY COUPLED ARGON PLASMA - ATOMIC EMISSION SPECTROSCOPY (ICP-AES) $\ldots \ldots \ldots \ldots \ldots \ldots \ldots \ldots \ldots \ldots \ldots$

4. MERCURY RELEASE AS A FUNCTION OF TEMPERATURE $\ldots \ldots \ldots \ldots \ldots$

5. AMALGAM DEGRADATION AS A FUNCTION OF $\mathrm{pH} \ldots \ldots \ldots \ldots \ldots \ldots$

6. RESULTS OF MERCURY RELEASE AS A FUNCTION OF TEMPERATURE . . . . 7

6.1 TESTS PERFORMED AT $4^{\circ} \mathrm{C} \ldots \ldots \ldots \ldots \ldots \ldots \ldots \ldots \ldots \ldots \ldots \ldots \ldots \ldots$

6.2 TESTS PERFORMED AT AMBIENT TEMPERATURE $\ldots \ldots \ldots \ldots \ldots \ldots$

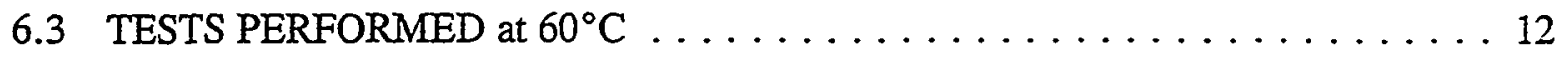

7. RESULTS OF MERCURY DEGRADATION AS A FUNCTION OF $\mathrm{pH} \ldots \ldots \ldots 13$

7.1 CHANGES IN THE FINAL $\mathrm{pH}$ OF THE LEACHATES $\ldots \ldots \ldots \ldots \ldots$

7.2 MERCURY LEACHING RESULTS $\ldots \ldots \ldots \ldots \ldots \ldots \ldots \ldots \ldots$

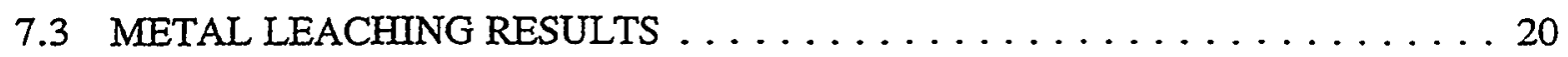

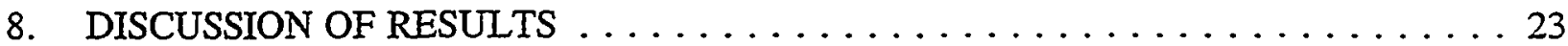

8.1 AMALGAMATED MERCURY $\ldots \ldots \ldots \ldots \ldots \ldots \ldots \ldots \ldots \ldots \ldots \ldots$

8.2 MERCURIC SULFIDE IMMOBILIZATION $\ldots \ldots \ldots \ldots \ldots \ldots \ldots \ldots$

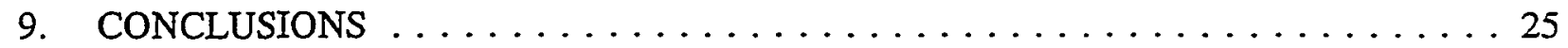

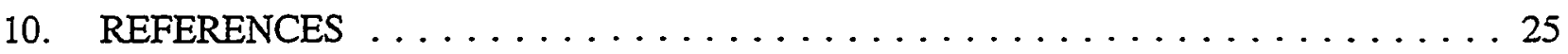

APPENDIX A: LEACHING TEST DATA $\ldots \ldots \ldots \ldots \ldots \ldots \ldots \ldots \ldots \ldots \ldots \ldots$

APPENDIX B: LEACHING RESULTS SORTED BY SAMPLE TYPE . . . . . . . B-1 



\section{LIST OF FIGURES}

Figure

Page

1 Vapor-concentration curve of pure mercury as a function of temperature $\ldots \ldots \ldots$

2 Mercury concentration in headspace at $4^{\circ} \mathrm{C} \ldots \ldots \ldots \ldots \ldots \ldots \ldots$

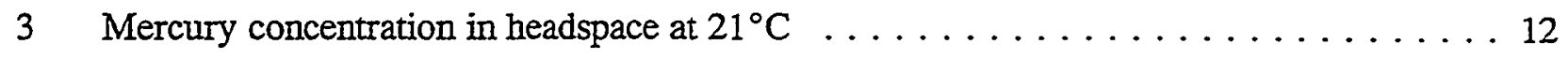

4 Mercury concentration in headspace at $60^{\circ} \mathrm{C} \ldots \ldots \ldots \ldots$

5 Change in $\mathrm{pH}$ for the LANL amalgam series $\ldots \ldots \ldots \ldots \ldots \ldots$

6 Change in $\mathrm{pH}$ for the FERN amalgam series $\ldots \ldots \ldots \ldots \ldots \ldots$

7 Change in $\mathrm{pH}$ for the OR amalgam series . . . . . . . . . . . . . 16

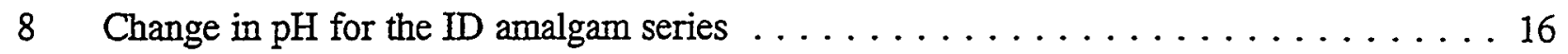

9 Normalized mercury leachability of each type of amalgam at $\mathrm{pH} 3 \ldots \ldots$

10 Normalized mercury leachability of each type of amalgam at $\mathrm{pH} 5 \ldots \ldots \ldots$

11 Normalized mercury leachability of each type of amalgam at $\mathrm{pH} 7 \ldots$. . . . . . . 19

12 Normalized mercury leachability of each type of amalgam at $\mathrm{pH} 12.5 \ldots \ldots$

13 Metals present in the blank . . . . . . . . . . . . . . . . . 21

14 Metals present in the leachates of the mercury standard . . . . . . . . . . . 21

15 Metals present in the leachates of the FERN amalgams $\ldots \ldots \ldots \ldots \ldots \ldots$

16 Metals present in the Ieachates of the LANL amalgam . . . . . . . . . . . . 22

17 Metals present in the leachates of the OR amalgams $\ldots \ldots \ldots \ldots \ldots \ldots$

18 Metals present in the leachates of the $\mathrm{ID}$ amalgam $\ldots \ldots \ldots \ldots \ldots \ldots \ldots \ldots$ 


\section{LIST OF TABLES}

Table

Page

1 Vapor concentration of pure mercury over the temperature range investigated . . . . . 5

2 Summary of data for the samples maintained at $4^{\circ} \mathrm{C} \ldots \ldots \ldots \ldots$

3 Summary of data for the samples maintained at $21^{\circ} \mathrm{C} \ldots \ldots \ldots \ldots \ldots$

4 Summary of data for the samples maintained at $60^{\circ} \mathrm{C} \ldots \ldots \ldots \ldots$

5 Mercury leachability (micrograms per liter) measured for different amalgams . . . . . 17

6 Normalized (percent) mercury leachability for different amalgams . . . . . . . . . . 17

A.1 Leaching results (milligrams per liter) obtained at 2 weeks $-\mathrm{pH} 3 \ldots \ldots$

A.2 Leaching results (milligrams per liter) obtained at 2 weeks $-\mathrm{pH} 5 \ldots \ldots$

A.3 Leaching results (milligrams per liter) obtained at 2 weeks $-\mathrm{pH} 7 \ldots \ldots$

A.4 Leaching results (milligrams per liter) obtained at 2 weeks $-\mathrm{pH} 12.5 \ldots \ldots$. . . . .

A.5 Leaching results (milligrams per liter) obtained at 1 month $-\mathrm{pH} 3 \ldots \ldots$. . . . . A

A.6 Leaching results (milligrams per liter) obtained at 1 month $-\mathrm{pH} 5 \ldots \ldots$

A.7 Leaching results (milligrams per liter) obtained at 1 month $-\mathrm{pH} 7 \ldots \ldots$

A.8 Leaching results (milligrams per liter) obtained at 1 month $-\mathrm{pH} 12.5 \ldots \ldots$. . . . .

A.9 Leaching results (milligrams per liter) obtained at 2 months $-\mathrm{pH} 3 \ldots \ldots$. . . . . A

A.10 Leaching results (milligrams per liter) obtained at 2 months $-\mathrm{pH} 5 \ldots \ldots$ A 12

A.11 Leaching results (milligrams per liter) obtained at 2 months $-\mathrm{pH} 7 \ldots$. . . . A 13

A.12 Leaching results (milligrams per liter) obtained at 2 months $-\mathrm{pH} 12.5 \ldots \ldots$ A-14

A.13 Leaching results (milligrams per liter) obtained at 3 months $-\mathrm{pH} 3 \ldots \ldots$. . . . . A

A.14 Leaching results (milligrams per liter) obtained at 3 months $-\mathrm{pH} 5 \ldots \ldots$ A-16

A.15 Leaching results (milligrams per liter) obtained at 3 months $-\mathrm{pH} 7 \ldots \ldots$ A-17

A.16 Leaching results (milligrams per liter) obtained at 3 months $-\mathrm{pH} 12.5 \ldots \ldots$ A-18

B.1 Leaching results (milligrams per liter) for the blank series . . . . . . . . . . B-3

B.2 Leaching results (milligrams per liter) for the mercury standard series . . . . . . . B-4

B.3 Leaching results (milligrams per liter) for the LANL series . . . . . . . . . . . . B-5

B.4 Leaching results (milligrams per liter) for the FERN series . . . . . . . . . . B-6

B.5 Leaching results (milligrams per liter) for the oR series $\ldots \ldots \ldots \ldots \ldots \ldots$

B.6 Leaching results (milligrams per liter) for the $\mathrm{D}$ series $\ldots \ldots \ldots \ldots \ldots$ 


\section{ACRONYMS}

$\begin{array}{ll}\text { ADA } & \text { ADA Technologies } \\ \text { AMLGM } & \text { Amalgamation } \\ \text { ASTM } & \text { American Society for Testing and Materials } \\ \text { CAA } & \text { Clean Air Act } \\ \text { CVAA } & \text { Cold vapor atomic absorption } \\ \text { DI } & \text { Deionized water } \\ \text { DOE } & \text { U.S. Department of Energy } \\ \text { EPA } & \text { U.S. Environmental Protection Agency } \\ \text { FERN } & \text { Fernald } \\ \text { ICP-AES } & \text { Inductively Coupled Argon Plasma-Atomic Emission Spectroscopy } \\ \text { INEEL } & \text { Idaho National Engineering and Environmental Laboratory } \\ \text { LANL } & \text { Los Alamos National Laboratory } \\ \text { LDR } & \text { Land Disposal Restrictions } \\ \text { MLLW } & \text { Mixed Low Level Waste } \\ \text { MWFA } & \text { Mixed Waste Focus Area } \\ \text { NFS } & \text { Nuclear Fuel Services } \\ \text { ORNL } & \text { Oak Ridge National Laboratory } \\ \text { ppb } & \text { Parts per billion } \\ \text { ppm } & \text { Parts per million } \\ \text { RCRA } & \text { Resource Conservation and Recovery Act } \\ \text { TCLP } & \text { Toxicity Characteristic Leaching Procedure } \\ \text { TLV } & \text { Threshold Limiting Value } \\ \text { UTS } & \text { Universal Treatment Standard }\end{array}$




\section{EXECUTIVE SUMMARY}

This report covers work performed during FY 1998 in support of treatment demonstrations conducted for the Mercury Working Group. In order to comply with the requirements of the Resource Conservation and Recovery Act, as implemented by the U.S. Environmental Protection Agency (EPA), the U.S. Department of Energy (DOE) must apply amalgamation, the treatment standard for radioactively contaminated mercury, before disposing of these wastes. The Mercury Working Group under the Mixed Waste Focus Area sponsored a demonstration in which two commercial vendors demonstrated their technologies for the treatment of radioactive mercury from various DOE sites. The project, described in this report, addresses the need for data on the vapor pressure and degradation occurring in amalgamated mercury mixed low-level wastes generated during these demonstrations under a variety of conditions.

A set of experiments studied the release of mercury above the headspace of amalgams as a function of temperature. Three temperatures were selected: $4^{\circ} \mathrm{C}$, ambient, and $60^{\circ} \mathrm{C}$. Results showed that compounds made with sulfur do not release mercury while those amalgams made with metals release mercury at a level comparable to that of pure mercury.

Another set of experiments studied the degradation of the amalgams as a function of the $\mathrm{pH}$ of the leachant in which they were immersed. Four $\mathrm{pH}$ values were selected: (1) $\mathrm{pH} \sim 3$-constituted by EPA fluid \#2 from the Toxicity Characteristic Leaching Procedure (TCLP) test, (2) $\mathrm{pH} \sim 5-$ constituted by EPA fluid \#1 from the TCLP test, (3) $\mathrm{pH} \sim 7-$ using deionized water, and (4) $\mathrm{pH} \sim 12.5-$ using a saturated solution of $\mathrm{Ca}(\mathrm{OH})_{2}$. The leachates were analyzed after 2 weeks, 1 month, 2 months, and 3 months for mercury and trace metals.

Even though the leach test conditions selected were unlikely to reflect those of a disposal site, the goal was to submit the amalgams to extreme conditions where the mechanisms of degradation, if any, would prevail. Analytical results indicated that amalgams prepared with metals did not perform well at low (acidic) and neutral $\mathrm{pH}$, releasing mercury and metals into the leachate solutions. These amalgams tended to perform better in alkaline solution. Additionally, the sulfurbased amalgams appeared to fare better over the entire $\mathrm{pH}$ range evaluated. 


\section{BACKGROUND}

Significant quantities of radioactive mercury waste [mixed low-level waste (MLLW)] are currently stored at the U.S. Department of Energy (DOE) facilities. In order to meet the U.S. Environmental Protection Agency (EPA) Land Disposal Restrictions (LDR), the treatment standard for this type of waste under the Resource Conservation and Recovery Act (RCRA), as set forth by the EPA (40 CFR 268.40), is amalgamation (AMLGM). The EPA defines the term as "amalgamation of liquid, elemental mercury contaminated with radioactive materials utilizing inorganic reagents such as copper, zinc, nickel, gold, and sulfur that result in a nonliquid, semisolid amalgam and thereby reducing potential emissions of elemental mercury vapors to the air." The adherence to a defined technology-based treatment standard qualifies the treated waste as LDR compliant.

As stated in the EPA definition, the purpose of the treatment is to reduce the emission of elemental mercury vapor in the environment. Different metals can form an amalgam with mercury (e.g., tin, cadmium, zinc, and copper), while sulfur forms mercury sulfide compounds. The EPA has accepted sulfur as a possible reagent for meeting the treatment standard. It has to be noted that even though sulfur fits the treatment standard for amalgamation, this material does not amalgamate mercury; it forms low-solubility mercury compounds. An amalgam is an alloy containing mercury, and sulfur is a nonmetallic element; however, after making this distinction, the terminology of sulfur-amalgam may be used throughout the report.

Previous bench-scale work performed at the Oak Ridge Y-12 Plant indicated that amalgams of mercury made with metals released almost as much mercury vapor as pure mercury itself, while amalgams made with sulfur released only small amounts of mercury. ${ }^{1}$

The Mercury Working Group sponsored a demonstration in which two vendors-Nuclear Fuel Services, Inc. (NFS), and ADA Technologies (ADA)-applied their technologies to amalgamate radioactive mercury originating from different DOE sites. NFS treated contaminated mercury from the Oak Ridge Reservation (referred to as OR in the sample numbering) and Idaho National Engineering and Environmental Laboratory (INEEL, referred to as ID). The proprietary process of NFS relies upon the use of metals. ADA treated contaminated mercury from Los Alamos National Laboratory (referred to as LANL in the sample numbering) and Fernald (referred to as FERN) by applying a proprietary process based upon the use of sulfur. 


\section{INTRODUCTION}

One of the primary performance requirements specified in the Mixed Waste Focus Area (MWFA) Technology Development Requirements Document - Mercury Amalgamation ${ }^{2}$ - is related to vapor emissions: "The process must not release mercury vapors into the environment above the limits established by the applicable air permit [in accordance with Clean Air Act (CAA) requirements]. In addition, the process should not expose operators to mercury vapors above the established Threshold Limiting Value (TLV) of $0.05 \mathrm{mg} / \mathrm{m}^{3}$." Another part states: "The final waste form must exhibit insignificant decomposition in a temperature range of $40^{\circ}$ to $140^{\circ} \mathrm{F}$ and in environments of all $\mathrm{pH}$ ranges, especially alkaline environments. The temperature range provided correlates to environments common to DOE mixed waste storage facilities. Using the TLV as a basis, the final waste form must have a vapor pressure of less than $10^{-6}$ torr at $140^{\circ} \mathrm{F} . "$

"Vapor pressure" is defined as the pressure at which a liquid or solid is in equilibrium with its vapor at a given temperature. The property of vapor pressure depends only upon the temperature and the composition of the material considered. For a typical liquid, a constant and reproducible vapor pressure exists, which will increase only with a temperature increase. ${ }^{3}$

The description given by the MWFA defines the scope of the study: (a) measuring mercury vapor pressure as a function of temperature - over the range of 4 to $60^{\circ} \mathrm{C}$ - and (b) evaluating the effect of $\mathrm{pH}$ on the possible degradation of the amalgam and then correlating this degradation with the mercury vapor pressure in the headspace above the sample and solution.

Two experimental methods are provided by the EPA ${ }^{4}$ and the American Society for Testing and Materials (ASTM) ${ }^{5}$ for measuring mercury vapor pressure: the isoteniscope procedure and the gas saturation procedure. The latter appeared to be well suited for the work described in this document. The modified test procedure used in this study was very similar to the static headspace analysis method used by Kriger and Turner. ${ }^{6}$ In this technique, the mercury vapor pressure is allowed to reach equilibrium in a static headspace, and the mercury concentration (mass/volume) in the headspace is subsequently measured using a commercial mercury vapor analyzer. They demonstrated that a portable commercial mercury analyzer can provide fast and reliable measurement of the mercury content in a sample and performed comparative tests of their technique and approved EPA methods (Method 245.1). Satisfactory correlations - from 75\% (in the worst case) to $103 \%$ - were obtained. 


\section{EQUIPMENT DESIGN}

\subsection{MERCURY VAPOR ANALYZER}

The instrument used for measurement of the vapor pressure of mercury was a Jerome 431 goldfilm mercury vapor analyzer from Arizona Instruments (Phoenix, Arizona). This instrument has a 13-s response time, is battery operated, and can run for $6 \mathrm{~h}$ before being recharged. The digital display can provide results in either milligrams per cubic meter or nanograms. The range of detection is 0.000 to $0.999 \mathrm{mg}$ per cubic meter of mercury. The sensitivity of the instrument is $0.003 \mathrm{mg} / \mathrm{m}^{3}$, which corresponds to $0.3 \mathrm{ng}$ of mercury, considering that the volume of air analyzed is $87.5 \mathrm{~mL}$. This sensitivity is well below the TLV value of $0.05 \mathrm{mg} / \mathrm{m}^{3}$. The air sampling is made with the aid of an internal pump that operates at a rate of $750 \mathrm{~cm}^{3} / \mathrm{min}$. The air flows through a guard column packed with soda lime for removing moisture and acid gases. The resulting dry vapor is deposited onto a gold film, which forms an amalgam with mercury, thus increasing the electrical resistance of the film. This specific instrument is stable and selective for mercury, and unlike other ultraviolet analyzers, is not prone to interferences such as from water vapor and hydrocarbons. When the sensor approaches its saturation limit, the instrument provides a warning. The regeneration of the sensor takes about $30 \mathrm{~min}$.

\subsection{COLD VAPOR ATOMIC ABSORPTION}

The instrument used for determination of mercury content in solution during the $\mathrm{pH}$ tests was a PS 200 automated mercury analyzer, from Lehman Labs. Its detection limit is $\sim 5 \mu \mathrm{g} / \mathrm{L}$. EPA protocols (SW846) were followed during use of this instrument.

\subsection{INDUCTIVELY COUPLED ARGON PLASMA - ATOMIC EMISSION SPECTROSCOPY (ICP-AES)}

The solution in which the amalgam samples were immersed was analyzed for total metals by ICPAES. The instrument used was a Thermo-Jarrell Ash model 61E-trace. EPA protocols (SW846) were followed for use of this instrument.

\section{MERCURY RELEASE AS A FUNCTION OF TEMPERATURE}

The objective of this first set of experiments was to study the effect of temperature on the mercury vapors released from the various amalgams and compounds. The Technology Development 
Requirements Document (2) indicates that the range of temperature usually found in DOE MLLW storage varies from 4 to $60^{\circ} \mathrm{C}$. Consequently, measurements were made at the following temperatures: $4^{\circ} \mathrm{C}$, ambient $\left(20^{\circ} \mathrm{C}\right)$, and $60^{\circ} \mathrm{C}$.

A weighed sample of amalgam was placed in a $\mathrm{Kapak}^{\circ}$ pouch, which was then closed by heat sealing. The pouch was not completely filled with air to permit volume changes during the experiment. The use of the pouch facilitated sampling. The bag collapsed on itself when the air was withdrawn for analysis and was easily punctured with the needle of the syringe used for sampling. After completion of the sampling, performed in triplicate, the bag was resealed. The same protocol was followed for each temperature studied.

Preliminary tests were performed to determine the need for dilution of the headspace samples. It was found that some of the amalgams, as well as the mercury standard, saturated the sensor of the analyzer when an undiluted analysis was performed. Volumes of 0.1 to $3 \mathrm{~mL}$ of the headspace sample diluted to a total of $87.5 \mathrm{~mL}$ by clean room air were found to be appropriate for use in this set of experiments. Measurements were made at various time intervals to verify that the data obtained were representative of an equilibrium condition.

The objectives of these tests were to measure the release of elemental mercury vapor over a given set of conditions for each candidate waste form and to compare the results with pure elemental mercury vapor of untreated waste. The literature does not provide tables of vapor concentration of pure mercury as a function of the temperature but rather expressed the vapor pressure as a function of the temperature. However, by using the ideal gas law presented in Eq.(1), such a table was generated, as seen in Table 1 and illustrated in Fig.1.

$$
p=(w / M)(\mathrm{R} T / v),
$$

where

$$
\begin{aligned}
& p=\text { vapor pressure of the sample }(\mathrm{Pa}), \\
& w=\text { mass of vaporized material }(\mathrm{g}), \\
& M=\text { molecular weight of mercury, } \\
& \mathrm{R}=\text { gas constant }\left(8.31 \mathrm{~Pa} \cdot \mathrm{m}^{2} \cdot \mathrm{mol}^{-1} \cdot \mathrm{K}^{-1}\right),
\end{aligned}
$$


Table 1. Vapor concentration of pure mercury over the temperature range investigated ${ }^{a}$

\begin{tabular}{|l|l|l|l|l|l|l|l|l|l|l|l|l|l|}
\hline $\begin{array}{c}\mathrm{T} \\
\left({ }^{\circ} \mathrm{C}\right)\end{array}$ & $\begin{array}{l}{[\mathrm{Hg}]} \\
\left(\mathrm{mg} / \mathrm{m}^{3}\right)\end{array}$ & $\begin{array}{c}\mathrm{T} \\
\left({ }^{\circ} \mathrm{C}\right)\end{array}$ & $\begin{array}{l}{[\mathrm{Hg}]} \\
\left(\mathrm{mg} / \mathrm{m}^{3}\right)\end{array}$ & $\begin{array}{c}\mathrm{T} \\
\left({ }^{\circ} \mathrm{C}\right)\end{array}$ & $\begin{array}{l}{[\mathrm{Hg}]} \\
\left(\mathrm{mg} / \mathrm{m}^{3}\right)\end{array}$ & $\begin{array}{c}\mathrm{T} \\
\left({ }^{\circ} \mathrm{C}\right)\end{array}$ & $\begin{array}{l}{[\mathrm{Hg}]} \\
\left(\mathrm{mg} / \mathrm{m}^{3}\right)\end{array}$ & $\begin{array}{c}\mathrm{T} \\
\left({ }^{\circ} \mathrm{C}\right)\end{array}$ & $\begin{array}{l}{[\mathrm{Hg}]} \\
\left(\mathrm{mg} / \mathrm{m}^{3}\right)\end{array}$ & $\begin{array}{c}\mathrm{T} \\
\left({ }^{\circ} \mathrm{C}\right)\end{array}$ & $\begin{array}{l}{[\mathrm{Hg}]} \\
\left(\mathrm{mg} / \mathrm{m}^{3}\right)\end{array}$ & $\begin{array}{c}\mathrm{T} \\
\left({ }^{\circ} \mathrm{C}\right)\end{array}$ & $\begin{array}{l}{[\mathrm{Hg}]} \\
\left(\mathrm{mg} / \mathrm{m}^{3}\right)\end{array}$ \\
\hline 1 & 2.42 & 11 & 6.10 & 21 & 14.37 & 31 & 31.93 & 41 & 67.32 & 51 & 135.28 & 61 & 260.30 \\
2 & 2.67 & 12 & 6.63 & 22 & 15.54 & 32 & 34.38 & 42 & 72.15 & 52 & 144.37 & 62 & 276.76 \\
3 & 2.94 & 13 & 7.27 & 23 & 16.93 & 33 & 37.22 & 43 & 77.68 & 53 & 154.68 & 63 & 295.27 \\
4 & 3.20 & 14 & 7.91 & 24 & 18.31 & 34 & 40.04 & 44 & 83.18 & 54 & 164.92 & 64 & 313.67 \\
5 & 3.53 & 15 & 8.66 & 25 & 19.91 & 35 & 43.30 & 45 & 89.48 & 55 & 176.58 & 65 & 334.29 \\
6 & 3.86 & 16 & 9.41 & 26 & 21.51 & 36 & 46.53 & 46 & 95.74 & 56 & 188.16 & 66 & 354.79 \\
7 & 4.25 & 17 & 10.28 & 27 & 23.36 & 37 & 50.26 & 47 & 102.89 & 57 & 201.28 & 67 & 377.92 \\
8 & 4.65 & 18 & 11.15 & 28 & 25.20 & 38 & 53.96 & 48 & 110.00 & 58 & 214.33 & 68 & 400.91 \\
9 & 5.11 & 19 & 12.17 & 29 & 27.34 & 39 & 58.22 & 49 & 118.10 & 59 & 229.08 & 69 & 426.72 \\
10 & 5.57 & 20 & 13.18 & 30 & 29.47 & 40 & 62.46 & 50 & 126.14 & 60 & 243.75 & 70 & 452.39 \\
\hline
\end{tabular}

${ }^{a}$ Calculations based on standard values obtained from CRC Handbook of Chemistry and Physics, CRC Press, Boca Raton, Fla., $47^{\text {th }}$ edition, pp. D-108.

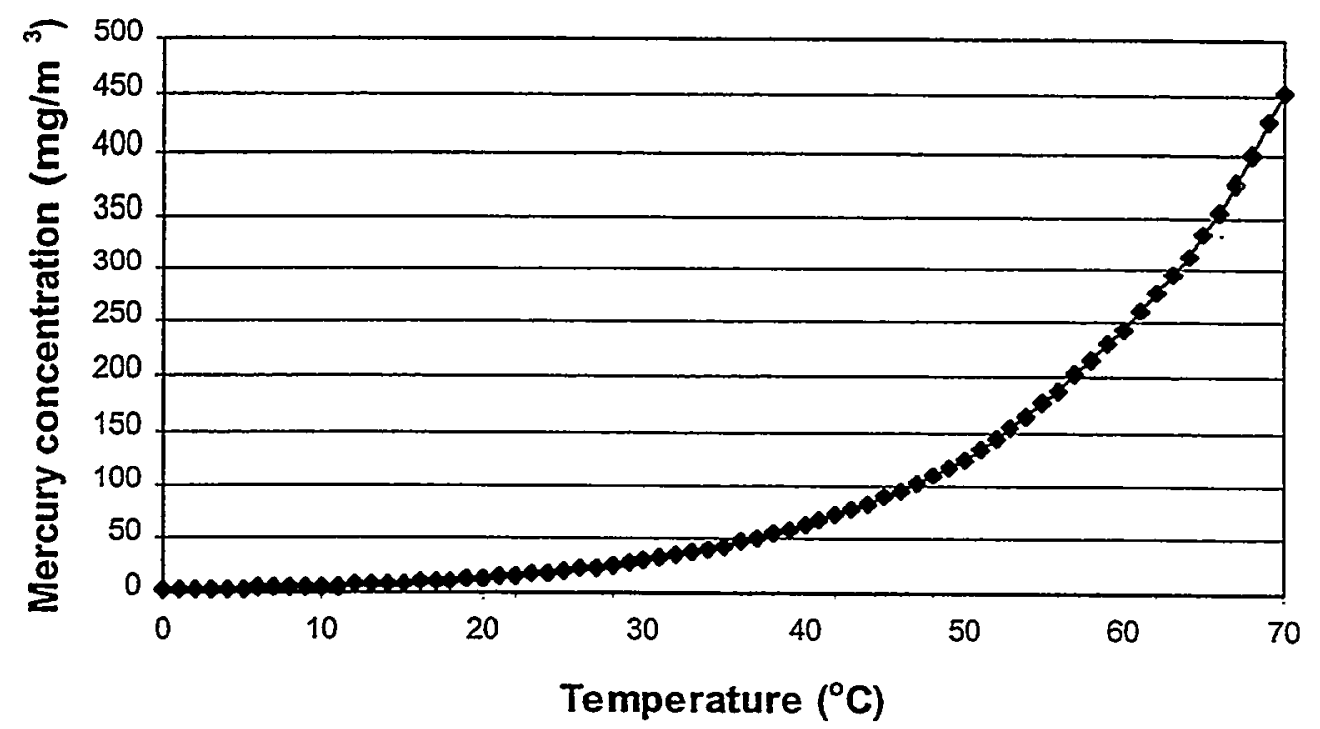

Fig. 1. Vapor-concentration curve of pure mercury as a function of temperature. 


$$
\begin{aligned}
& T=\text { temperature }(\mathrm{K}) \\
& v=\text { volume analyzed }\left(\mathrm{m}^{3}\right)
\end{aligned}
$$

\section{AMALGAM DEGRADATION AS A FUNCTION OF pH}

The objective of the second set of experiments was to study the effect of $\mathrm{pH}$ on the release of mercury as well as on waste-form degradation. Four solutions representing different $\mathrm{pH}$ values were selected for that test:

1. a $\mathrm{pH}$ of $\sim 12.5$ (the $\mathrm{pH}$ of cementitious pore water), prepared from a saturated solution of $\mathrm{Ca}(\mathrm{OH})_{2}$ in deionized (DI) water;

2. a near-neutral pH (6 to 8$)$ made with DI water;

3. an acidic $\mathrm{pH}(\sim 5)$ made with the recipe for fluid \#1 from the EPA TCLP test $(5.7 \mathrm{~mL}$ of glacial acetic acid plus $64.3 \mathrm{~mL}$ of $1 \mathrm{~N} \mathrm{NaOH}$ solution in $1 \mathrm{~L}$ of DI water); and

4. an acidic $\mathrm{pH}(\sim 3)$ made with the recipe for fluid $\# 2(5.7 \mathrm{~mL}$ of glacial acetic acid in $1 \mathrm{~L}$ of DI water) from the EPA TCLP test.

The same experimental design described in Sect. 4 was also employed in these tests; however, this series was performed at ambient temperature. A known amount of amalgam was introduced into the pouch followed by $100 \mathrm{~mL}$ of the chosen leachant. The bag was sealed, placed in a secondary container, and allowed to cure at room temperature. After equilibration for a selected period of time, the leachate was removed from the pouch using a 60-mL syringe. It was then filtered using a $0.45-\mu \mathrm{m}$ syringe filter and finally preserved with $1 \mathrm{~mL}$ of concentrated uitrapure nitric acid. The solutions were subsequently analyzed for metals and mercury content. The samples did not undergo a digestion preparation step.

For each time interval selected ( 2 weeks, 1 month, 2 months, and 3 months), a blank and mercury standard were prepared in triplicate for each $\mathrm{pH}$ value studied. The four types of amalgam were also prepared in triplicate for each period of time and $\mathrm{pH}$ value. 


\section{RESULTS OF MERCURY RELEASE AS A FUNCTION OF TEMPERATURE}

As shown in Fig. 1 for pure mercury, the concentration of the mercury in the vapor phase is very sensitive to temperature. In these tests, the results obtained at ambient temperature were quite constant because of the small temperature fluctuation existing in the room; however, for the samples maintained in the refrigerator or in the oven, large fluctuations were observed as a result of changes in the temperature of the chamber. Once the door was opened to permit sampling of the first bag, the temperature changed; consequently, the data obtained no longer reflected the targeted temperature.

Some variation is reflected in the data presented in Tables 2, 3, and 4. It must be noted that the mercury used as the standard for our tests had been used for previous experiments; therefore, the data obtained might differ from the theoretical values because of the contamination present in this sample.

\subsection{TESTS PERFORMED AT $4^{\circ} \mathrm{C}$}

These samples were placed in a refrigerator set for $4^{\circ} \mathrm{C}$. After 3 days, a first set of measurements was taken. A 3-mL syringe was used for sampling the headspace in each bag and injecting the sample into the septum of the mercury analyzer. The tests were run in triplicate and then averaged. Data found in the literature indicate that the mercury concentration in the headspace should be $3.20 \mathrm{mg} / \mathrm{m}^{3}$ at $4^{\circ} \mathrm{C}$. However, because of the rise in temperature caused by opening the refrigerator door, some of the data were not collected at a temperature of $4^{\circ} \mathrm{C}$. The data obtained at three different times (after 3,11, and 13 days) are provided in Table 2. Figure 2 illustrates the average results obtained for each series of amalgam studied as well as a blank and a mercury standard. The theoretical values for pure mercury at 4,7 , and $10^{\circ} \mathrm{C}$ are also presented in the plot. 
Table 2. Summary of data for the samples maintained at $4^{\circ} \mathrm{C}^{\circ}$

\begin{tabular}{|c|c|c|c|}
\hline \multirow[b]{2}{*}{ Sample } & \multicolumn{3}{|c|}{$[\mathrm{Hg}]$ in the headspace $\left(\mathrm{mg} / \mathrm{m}^{3}\right)$} \\
\hline & 3 days & 11 days & 13 days \\
\hline BLK 8 & $0.000 \pm 0.000$ & $0.000 \pm 0.000$ & $0.004 \pm 0.000$ \\
\hline BLK 9 & $0.000 \pm 0.000$ & $0.000 \pm 0.000$ & $0.004 \pm 0.000$ \\
\hline BLK 10 & $\mathrm{nr}$ & $0.000 \pm 0.000$ & $0.000 \pm 0.000$ \\
\hline Average & $0.000 \pm 0.000$ & $0.000 \pm 0.000$ & $0.002 \pm 0.000$ \\
\hline $\mathrm{Hg}-6$ & $4.05 \pm 0.20$ & $2.25 \pm 0.11$ & $1.95 \pm 0.10$ \\
\hline $\mathrm{Hg}-9$ & $4.29 \pm 0.21$ & $2.43 \pm 0.11$ & $2.04 \pm 0.10$ \\
\hline $\mathrm{Hg}-10$ & $4.26 \pm 0.21$ & $2.78 \pm 0.12$ & $3.31 \pm 0.05$ \\
\hline Average & $4.17 \pm 0.21$ & $2.34 \pm 0.12$ & $2.00 \pm 0.08$ \\
\hline FERN-2 & $0.000 \pm 0.000$ & $0.000 \pm 0.000$ & $0.000 \pm 0.000$ \\
\hline FERN-4 & $0.000 \pm 0.000$ & $0.000 \pm 0.000$ & $0.005 \pm 0.000$ \\
\hline FERN-9 & $0.000 \pm 0.000$ & $0.000 \pm 0.000$ & $0.000 \pm 0.000$ \\
\hline Average & $0.000 \pm 0.000$ & $0.000 \pm 0.000$ & $0.002 \pm 0.000$ \\
\hline LANL-C & $0.029 \pm 0.000$ & $0.000 \pm 0.000$ & $0.000 \pm 0.000$ \\
\hline LANL-D & $0.000 \pm 0.000$ & $0.000 \pm 0.000$ & $0.000 \pm 0.000$ \\
\hline LANL-G & $0.000 \pm 0.000$ & $0.000 \pm 0.000$ & $0.000 \pm 0.000$ \\
\hline Average & $0.010 \pm 0.000$ & $0.000 \pm 0.000$ & $0.000 \pm 0.000$ \\
\hline OR-3 & $4.72 \pm 0.23$ & $4.30 \pm 0.21$ & $2.15 \pm 0.11$ \\
\hline OR-6 & $5.48 \pm 0.27$ & $5.46 \pm 0.21$ & $3.44 \pm 0.17$ \\
\hline OR-10 & $5.30 \pm 0.26$ & $5.49 \pm 0.27$ & $4.35 \pm 0.07$ \\
\hline Average & $5.17 \pm 0.26$ & $5.09 \pm 0.23$ & $3.31 \pm 0.12$ \\
\hline ID-3 & $4.52 \pm 0.23$ & $5.49 \pm 0.28$ & $3.94 \pm 0.07$ \\
\hline ID-6 & $4.93 \pm 0.24$ & $4.20 \pm 0.28$ & $2.68 \pm 0.14$ \\
\hline ID-8 & $4.29 \pm 0.21$ & $3.81 \pm 0.21$ & $4.02 \pm 0.10$ \\
\hline Average & $4.58 \pm 0.23$ & $4.50 \pm 0.25$ & $3.55 \pm 0.10$ \\
\hline
\end{tabular}

${ }^{a} \mathrm{BLK} 8, \mathrm{BLK} 9$ and BLK 10 were the sample names of the blanks used for this experiment. Similariy, $\mathrm{Hg}-6, \mathrm{Hg}-9$ and $\mathrm{Hg}-10$ were the sample names of the pure mercury used as control. 
Table 3. Summary of data for samples maintained at $21^{\circ} \mathrm{C}^{a}$

[Hg] in the headspace $\left(\mathrm{mg} / \mathrm{m}^{3}\right)$

\begin{tabular}{|c|c|c|c|c|}
\hline Sample & 2 days & 5 days & 13 days & 14 days \\
\hline BLK 1 & $0.000 \pm 0.000$ & $0.000 \pm 0.000$ & $0.000 \pm 0.000$ & $0.000 \pm 0.000$ \\
\hline BLK 2 & $0.000 \pm 0.000$ & $0.000 \pm 0.000$ & $0.000 \pm 0.000$ & $0.000 \pm 0.000$ \\
\hline BLK 3 & $\mathrm{nr}$ & $0.000 \pm 0.000$ & $0.000 \pm 0.000$ & $0.000 \pm 0.000$ \\
\hline Average & $0.000 \pm 0.000$ & $0.000 \pm 0.000$ & $0.000 \pm 0.000$ & $0.000 \pm 0.000$ \\
\hline $\mathrm{Hg}-1$ & $11.29 \pm 0.56$ & $9.74 \pm 0.49$ & $10.41 \pm 0.52$ & $9.95 \pm 0.50$ \\
\hline $\mathrm{Hg}-8$ & $11.26 \pm 0.56$ & $10.44 \pm 0.52$ & $10.09 \pm 0.50$ & $11.00 \pm 0.55$ \\
\hline $\mathrm{Hg}-12$ & $\mathrm{nr}$ & $10.62 \pm 0.53$ & $11.32 \pm 0.56$ & $11.55 \pm 0.58$ \\
\hline Average & $11.27 \pm 0.56$ & $10.27 \pm 0.51$ & $10.61 \pm 0.53$ & $10.83 \pm 0.54$ \\
\hline FERN-1 & $0.000 \pm 0.000$ & $0.000 \pm 0.000$ & $0.000 \pm 0.000$ & $0.000 \pm 0.000$ \\
\hline FERN-3 & $0.000 \pm 0.000$ & $0.000 \pm 0.000$ & $0.000 \pm 0.000$ & $0.020 \pm 0.000$ \\
\hline FERN-8 & $0.000 \pm 0.000$ & $0.000 \pm 0.000$ & $0.000 \pm 0.000$ & $0.000 \pm 0.000$ \\
\hline Average & $0.000 \pm 0.000$ & $0.000 \pm 0.000$ & $0.000 \pm 0.000$ & $0.007 \pm 0.000$ \\
\hline LANL-I & $0.000 \pm 0.000$ & $0.000 \pm 0.000$ & $0.000 \pm 0.000$ & $0.000 \pm 0.000$ \\
\hline LANL-B & $0.000 \pm 0.000$ & $0.000 \pm 0.000$ & $0.000 \pm 0.000$ & $0.000 \pm 0.000$ \\
\hline LANL-E & $0.000 \pm 0.000$ & $0.000 \pm 0.000$ & $0.000 \pm 0.000$ & $0.000 \pm 0.000$ \\
\hline Average & $0.000 \pm 0.000$ & $0.000 \pm 0.000$ & $0.000 \pm 0.000$ & $0.000 \pm 0.000$ \\
\hline OR-2 & $10.30 \pm 0.52$ & $9.77 \pm 0.49$ & $10.12 \pm 0.51$ & $9.36 \pm 0.47$ \\
\hline OR-7 & $10.06 \pm 0.50$ & $10.41 \pm 0.52$ & $10.65 \pm 0.53$ & $10.85 \pm 0.54$ \\
\hline OR-9 & $10.27 \pm 0.51$ & $10.47 \pm 0.52$ & $11.11 \pm 0.56$ & $9.63 \pm 0.48$ \\
\hline Average & $10.21 \pm 0.51$ & $10.22 \pm 0.51$ & $10.63 \pm 0.53$ & $9.95 \pm 0.50$ \\
\hline ID-1 & $9.89 \pm 0.49$ & $10.62 \pm 0.53$ & $10.53 \pm 0.52$ & $11.67 \pm 0.58$ \\
\hline ID-5 & $10.21 \pm 0.51$ & $10.35 \pm 0.52$ & $10.33 \pm 0.52$ & $11.75 \pm 0.57$ \\
\hline ID-7 & $10.03 \pm 0.50$ & $10.24 \pm 0.51$ & $10.12 \pm 0.51$ & $11.93 \pm 0.59$ \\
\hline Average & $10.04 \pm 0.50$ & $10.40 \pm 0.52$ & $10.33 \pm 0.52$ & $11.78 \pm 0.59$ \\
\hline
\end{tabular}

${ }^{a}$ BLK 1 , BLK 2 and BLK 3 were the sample names of the blanks used for this experiment. Similarly, $\mathrm{Hg}-1, \mathrm{Hg}-8$ and $\mathrm{Hg}-12$ were the sample names of the pure mercury used as control. 
Table 4. Summary of data for the samples maintained at $60^{\circ} \mathrm{C}^{a}$

$[\mathrm{Hg}]$ in the headspace $\left(\mathrm{mg} / \mathrm{m}^{3}\right)$

\begin{tabular}{lcccc} 
& & & & \\
Sample & 1 day & 4 days & 12 days & 13 days \\
\hline & & & & \\
BLK 4 & $0.000 \pm 0.000$ & $0.204 \pm 0.003$ & $0.117 \pm 0.002$ & $0.244 \pm 0.000$ \\
BLK 5 & $0.000 \pm 0.000$ & $0.146 \pm 0.002$ & $0.117 \pm 0.002$ & $0.241 \pm 0.000$ \\
Average & $0.000 \pm 0.000$ & $0.175 \pm 0.003$ & $0.117 \pm 0.002$ & $0.243 \pm 0.000$
\end{tabular}

\begin{tabular}{llrrr}
\hline $\mathrm{Hg}-4$ & $183.8 \pm 91.9$ & $108.9 \pm 27.3$ & $113.3 \pm 28.3$ & $232.3 \pm 58.1$ \\
$\mathrm{Hg}-5$ & $249.4 \pm 124.7$ & $83.1 \pm 20.8$ & $120.3 \pm 30.1$ & $120.3 \pm 30.1$ \\
$\mathrm{Hg}-11$ & $306.3 \pm 153.1$ & $77.0 \pm 19.3$ & $97.6 \pm 24.4$ & $151.9 \pm 15.2$ \\
Average & $216.6 \pm 123.2$ & $89.7 \pm 22.4$ & $110.4 \pm 27.6$ & $168.2 \pm 34.4$
\end{tabular}

\begin{tabular}{lllll}
\hline FERN-5 & $0.000 \pm 0.000$ & $0.263 \pm 0.004$ & $0.000 \pm 0.000$ & $0.003 \pm 0.000$ \\
FERN-6 & $0.000 \pm 0.000$ & $0.642 \pm 0.011$ & $0.292 \pm 0.005$ & $0.003 \pm 0.000$ \\
FERN-7 & $0.000 \pm 0.000$ & $0.175 \pm 0.003$ & $0.000 \pm 0.000$ & $0.000 \pm 0.000$ \\
Average & $0.000 \pm 0.000$ & $0.360 \pm 0.006$ & $0.097 \pm 0.002$ & $0.002 \pm 0.000$
\end{tabular}

\begin{tabular}{lllll}
\hline LANL-A & $0.000 \pm 0.000$ & $0.146 \pm 0.002$ & $0.088 \pm 0.002$ & $0.006 \pm 0.000$ \\
LANL-F & $0.000 \pm 0.000$ & $0.000 \pm 0.000$ & $0.204 \pm 0.003$ & $0.004 \pm 0.000$ \\
LANL-H & $0.000 \pm 0.000$ & $0.000 \pm 0.000$ & $0.175 \pm 0.003$ & $0.004 \pm 0.000$ \\
Average & $0.000 \pm 0.000$ & $0.049 \pm 0.001$ & $0.156 \pm 0.003$ & $0.005 \pm 0.000$
\end{tabular}

\begin{tabular}{lllrl}
\hline OR-1 & $107.2 \pm 26.8$ & $104.6 \pm 26.1$ & $132.1 \pm 33.0$ & $167.1 \pm 41.8$ \\
OR-5 & $\mathrm{nr}$ & $143.9 \pm 36.0$ & $88.8 \pm 22.2$ & $259.0 \pm 64.8$ \\
OR-8 & $133.9 \pm 33.5$ & $129.5 \pm 32.4$ & $140.9 \pm 35.2$ & $132.1 \pm 33.0$ \\
Average & $120.5 \pm 30.1$ & $126.0 \pm 31.5$ & $120.6 \pm 30.2$ & $186.1 \pm 46.5$
\end{tabular}

\begin{tabular}{lrrrr}
\hline $\mathrm{ID}-2$ & $69.1 \pm 17.3$ & $90.6 \pm 22.6$ & $179.8 \pm 45.0$ & $154.0 \pm 15.4$ \\
$\mathrm{ID}-4$ & $115.5 \pm 27.7$ & $101.1 \pm 25.3$ & $118.6 \pm 29.6$ & $129.5 \pm 13.0$ \\
$\mathrm{ID}-9$ & $74.4 \pm 18.6$ & $140.0 \pm 35.0$ & $323.8 \pm 80.9$ & $164.1 \pm 41.0$ \\
Average & $86.3 \pm 31.2$ & $110.5 \pm 27.6$ & $207.4 \pm 51.8$ & $149.2 \pm 23.1$
\end{tabular}

${ }^{\circ}$ BLK 4 and BLK 5 were the sample names of the blanks used for this experiment.

Similarly, $\mathrm{Hg}-4, \mathrm{Hg}-5$ and $\mathrm{Hg}-11$ were the sample names of the pure mercury used as control. 
The mercury concentrations are not completely accurate because the temperature was not constant over the series measurement. However, comparison with the values obtained for the blank and the pure mercury shows the trend developed by each amalgam. The amalgams made with sulfur (LANL and FERN series) appear to behave like the blank, while those made with metals (OR and ID series) appear to behave like pure mercury.

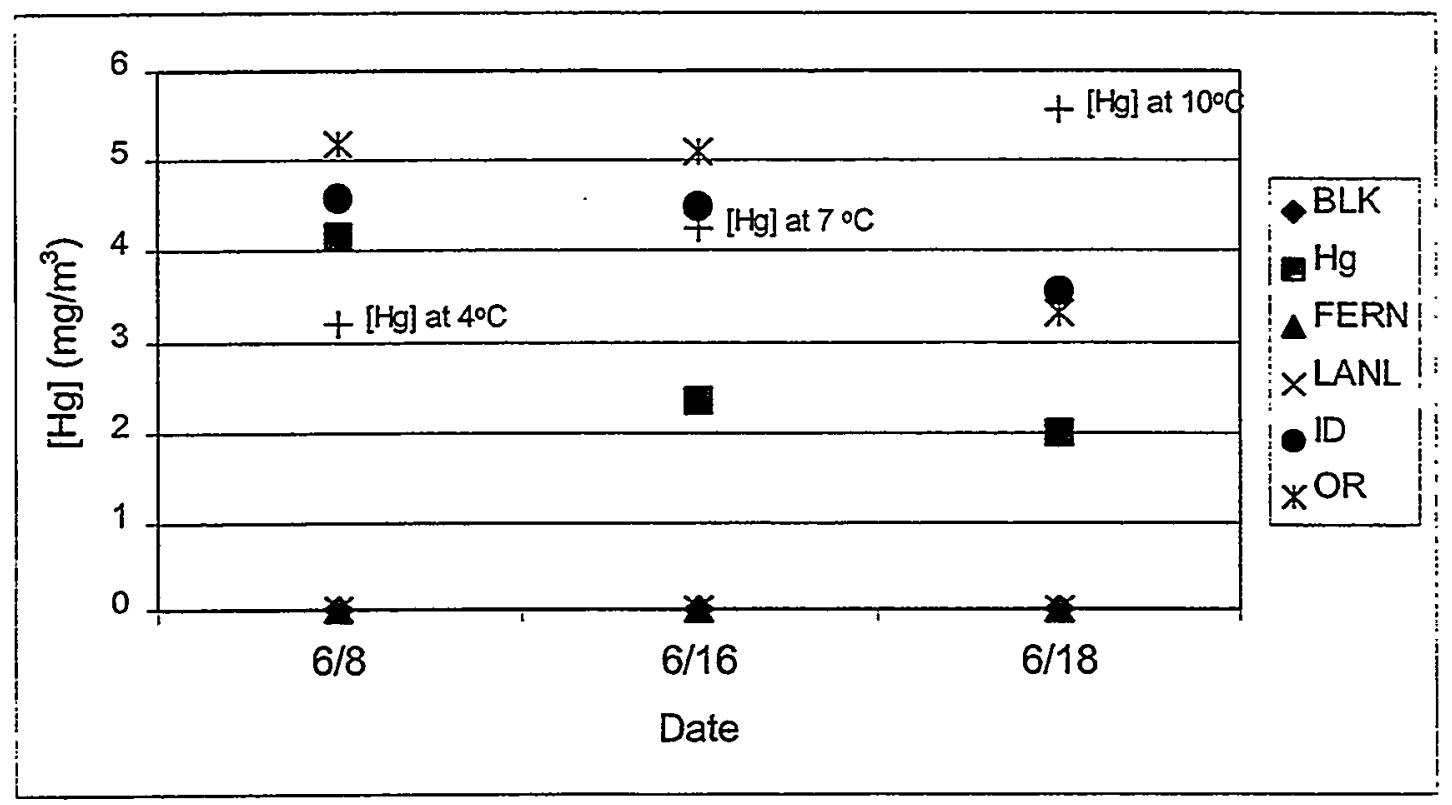

Fig. 2. Mercury concentration in headspace at $4^{\circ} \mathrm{C}$.

\subsection{TESTS PERFORMED AT AMBIENT TEMPERATURE}

The temperature inside the laboratory was quite constant (between 20 and $21^{\circ} \mathrm{C}$ ) when the measurements were performed on four different days. The mercury concentration found in the headspace at $21^{\circ} \mathrm{C}$ should be $14.5 \mathrm{mg} / \mathrm{m}^{3}$. The temperature fluctuations observed in the other experiments did not occur in this set, and more reliable values were obtained. The data are summarized in Table 3 . Figure 3 plots the average values obtained for each series; the theoretical values for pure mercury at 17 and $19^{\circ} \mathrm{C}$ are aiso provided. The same trend observed at $4^{\circ} \mathrm{C}$ was noted at room temperature: the amalgams made with sulfur behave like the blank, and the amalgams made with metals behave like pure mercury. 


\subsection{TESTS PERFORMED AT $60^{\circ} \mathrm{C}$}

For this series of tests, the data showed much fluctuation with the temperature drop that occurred when the oven was opened to obtain the sample for measurement. The theoretical mercury concentration at $60^{\circ} \mathrm{C}$ is $243.8 \mathrm{mg} / \mathrm{m}^{3}$. As with the samples maintained at $4^{\circ} \mathrm{C}$, no absolute data are generated, only comparative data with the blank and the pure mercury samples. The same trend observed with the other temperatures was also noted. The data obtained on four different days are compiled in Table 4 and illustrated in Fig. 4, where theoretical values for pure mercury at 45, 50, 55 , and $60^{\circ} \mathrm{C}$ are also presented.

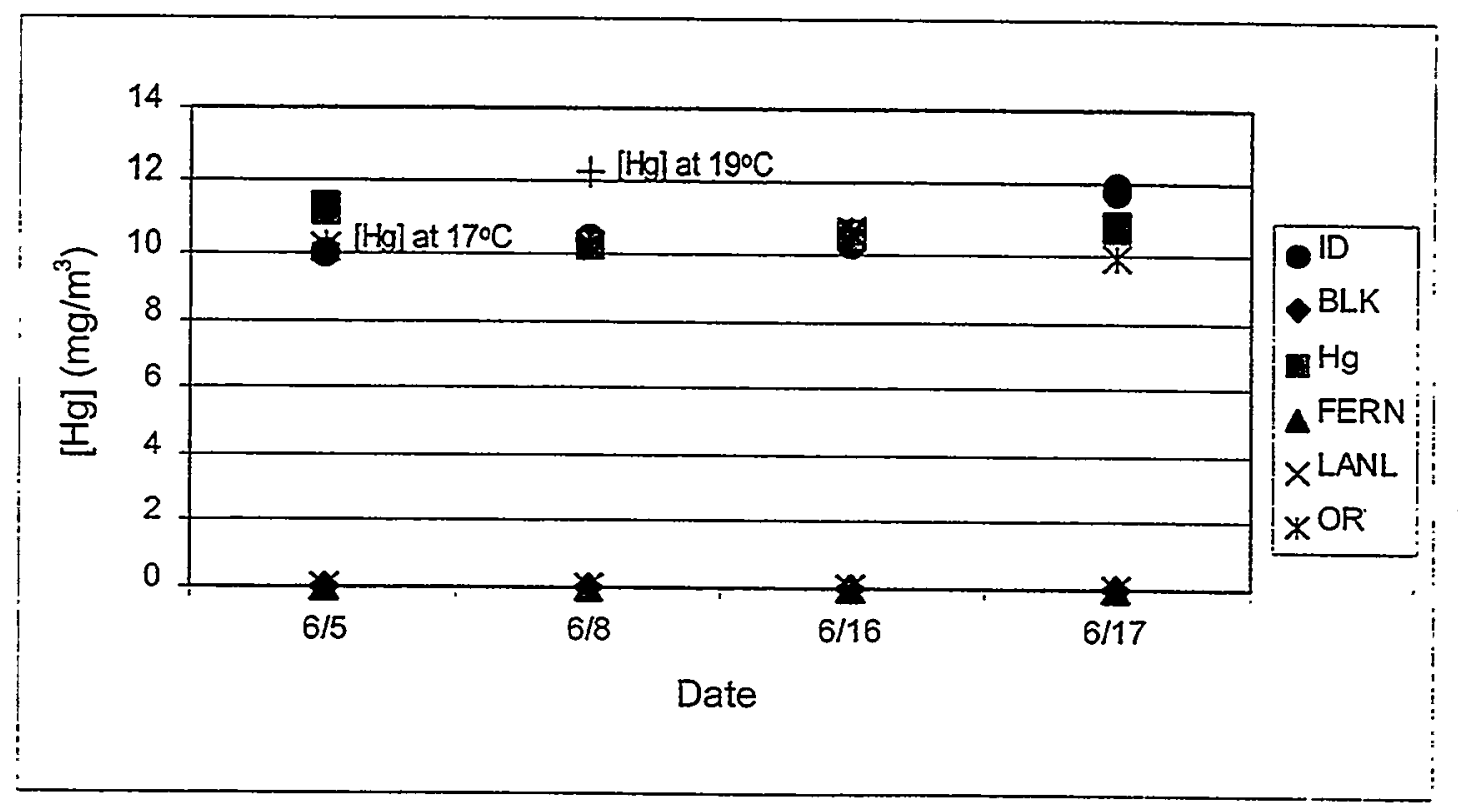

Fig. 3. Mercury concentration in headspace at $21^{\circ} \mathrm{C}$. 


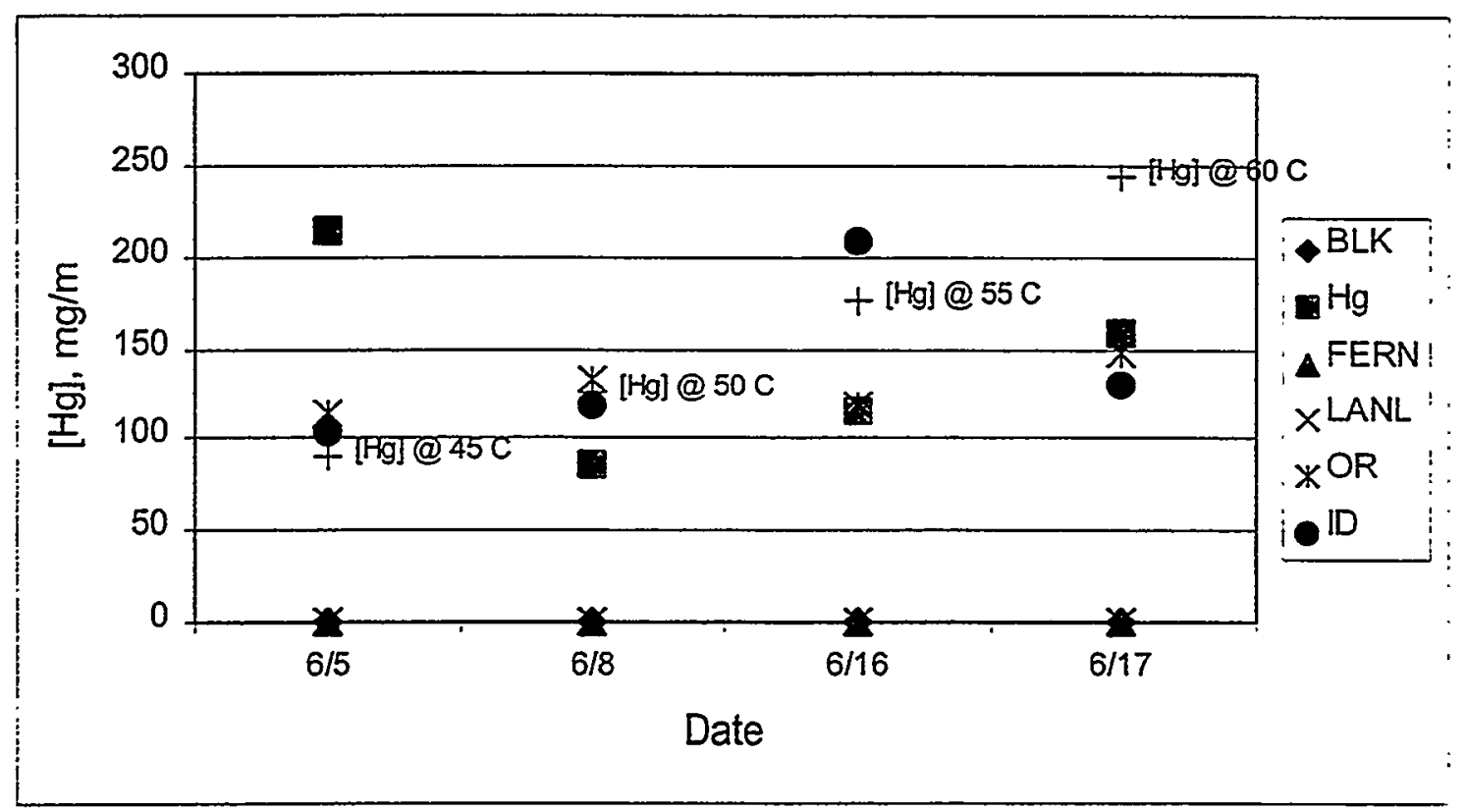

Fig. 4. Mercury concentration in headspace at $60^{\circ} \mathrm{C}$.

\section{RESULTS OF MERCURY DEGRADATION AS A FUNCTION OF $\mathrm{pH}$}

In this set of experiments, triplicate analyses were performed for each time interval and $\mathrm{pH}$ evaluated. The metal concentrations, expressed in milligrams per liter, were determined by ICP, while the mercury concentrations, expressed in micrograms per liter, were measured by cold vapor atomic absorption (CVAA). The data generated after 2 weeks, 1 month, 2 months, and 3 months of cure are presented in Tables A.1-A.16 located in Appendix A. A compilation of the average data obtained for each series is provided in Appendix B, Tables B.1-B.6. The weight of the amalgam used as well as the $\mathrm{pH}$ of the initial solution and the $\mathrm{pH}$ after cure are provided.

It is interesting to note that heterogeneity is observed in the mercury data obtained for some samples prepared in triplicate. Many of the samples presenting these differences were rerun to 
confirm the results, and the analyses confirm the heterogeneity in many cases. This may be explained by the presence of mercury that had not completely reacted with the amalgamating material. This hypothesis is very likely to be the case for the FERN samples. During the sample preparation, small spheres of shiny metallic mercury were observed in the black material, providing evidence that some mercury did not react completely. For the FERN and LANL series, with the black mercury sulfide material, this observation was readily made; however, for the gray OR and ID amalgams, it was difficult to note. A second hypothesis would be the presence in the leachate of small particulates of $\mathrm{HgS}$ that were not captured by the $0.45-\mu \mathrm{m}$ filter used. This observation was noted especially for the ID series, followed, to a lesser degree, by the OR series and then by the FERN and LANL series.

\subsection{CHANGES IN THE FINAL $\mathrm{pH}$ OF THE LEACHATES}

Except for the blank and mercury standard series, changes in the final $\mathrm{pH}$ values of the solutions were observed. At pH 3, all the solutions containing the various amalgams exhibited a final increase in $\mathrm{pH}$ with time. The amalgam made with the ID series appears to be the one for which the $\mathrm{pH}$ increased the most. At $\mathrm{pH} 5$, the FERN amalgams appear to produce the highest $\mathrm{pH}$ increase. At higher $\mathrm{pH}$ values, the two types of waste form are diverging: for the sulfur amalgams, the final $\mathrm{pH}$ of the solution decreases slightly at $\mathrm{pH} 7$ and severely at $\mathrm{pH} 12.5$, while the metalbased amalgams show an increase for $\mathrm{pH} 7$ and a small decrease for $\mathrm{pH} 12.5$. These changes are illustrated in Figs. 5-8. The reasons for this are discussed in Sect. 8.1.

\subsection{MERCURY LEACHING RESULTS}

The average mercury leaching results are compiled for easy comparison in Table 5. The results are expressed in micrograms per liter. All the amalgams show a decrease in the leachability of mercury compared with the pure mercury standard; however, the scale of the reduction is different. It is also interesting to remember that the Universal Treatment Standard (UTS) limit for 


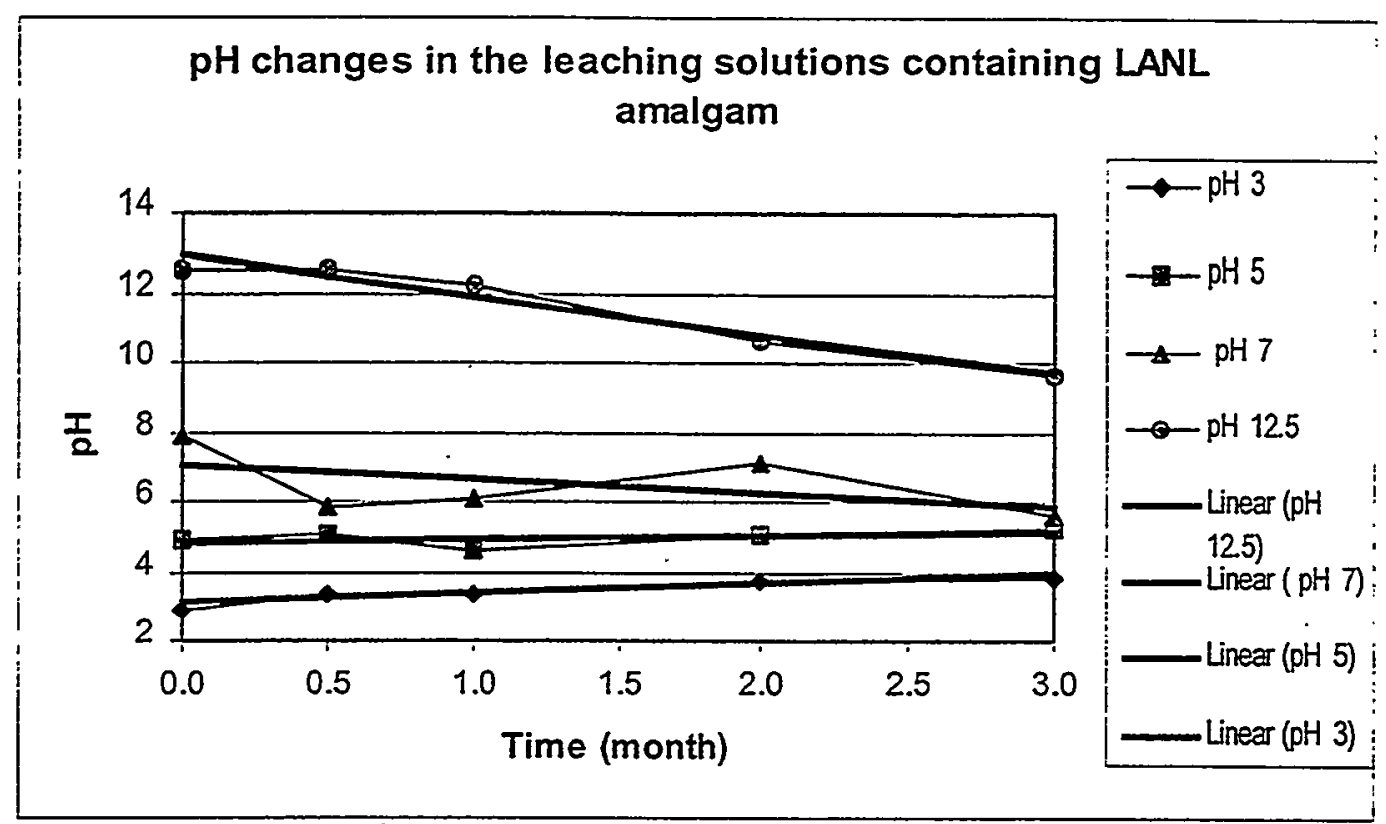

Fig. 5. Change in $\mathrm{pH}$ for the LANL amalgam series.

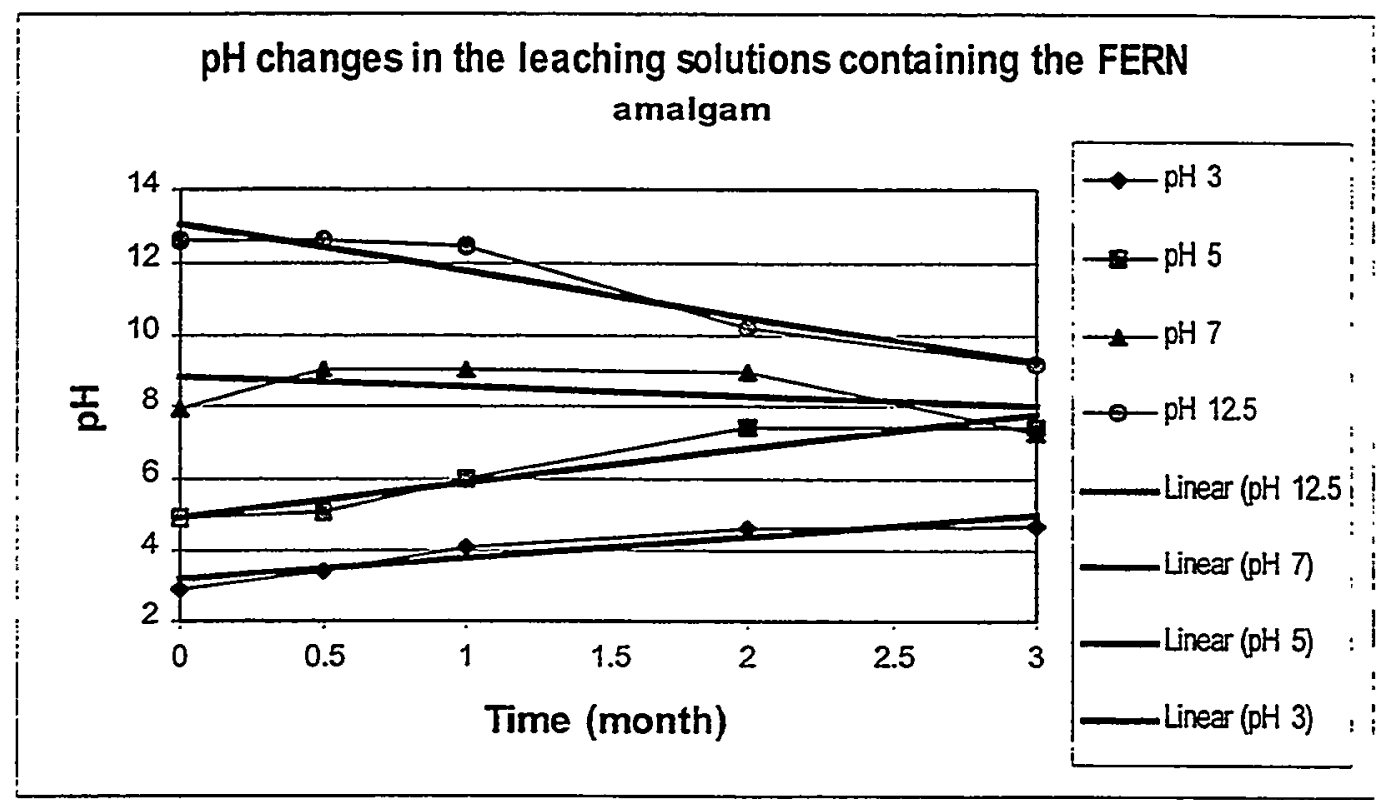

Fig. 6. Change in $\mathrm{pH}$ for the FERN amalgam series. 


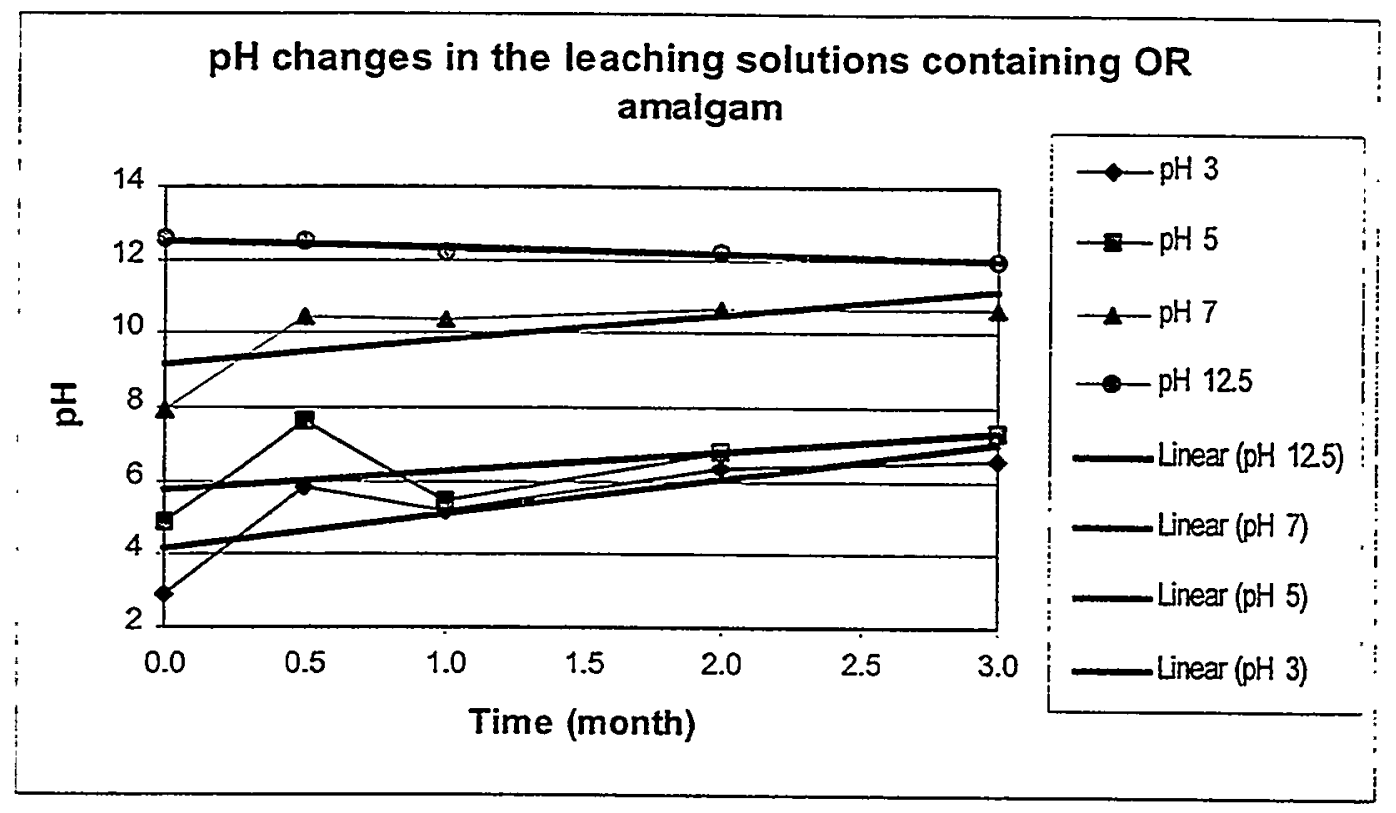

Fig. 7. Change in $\mathrm{pH}$ for the $\mathrm{OR}$ amalgam series.

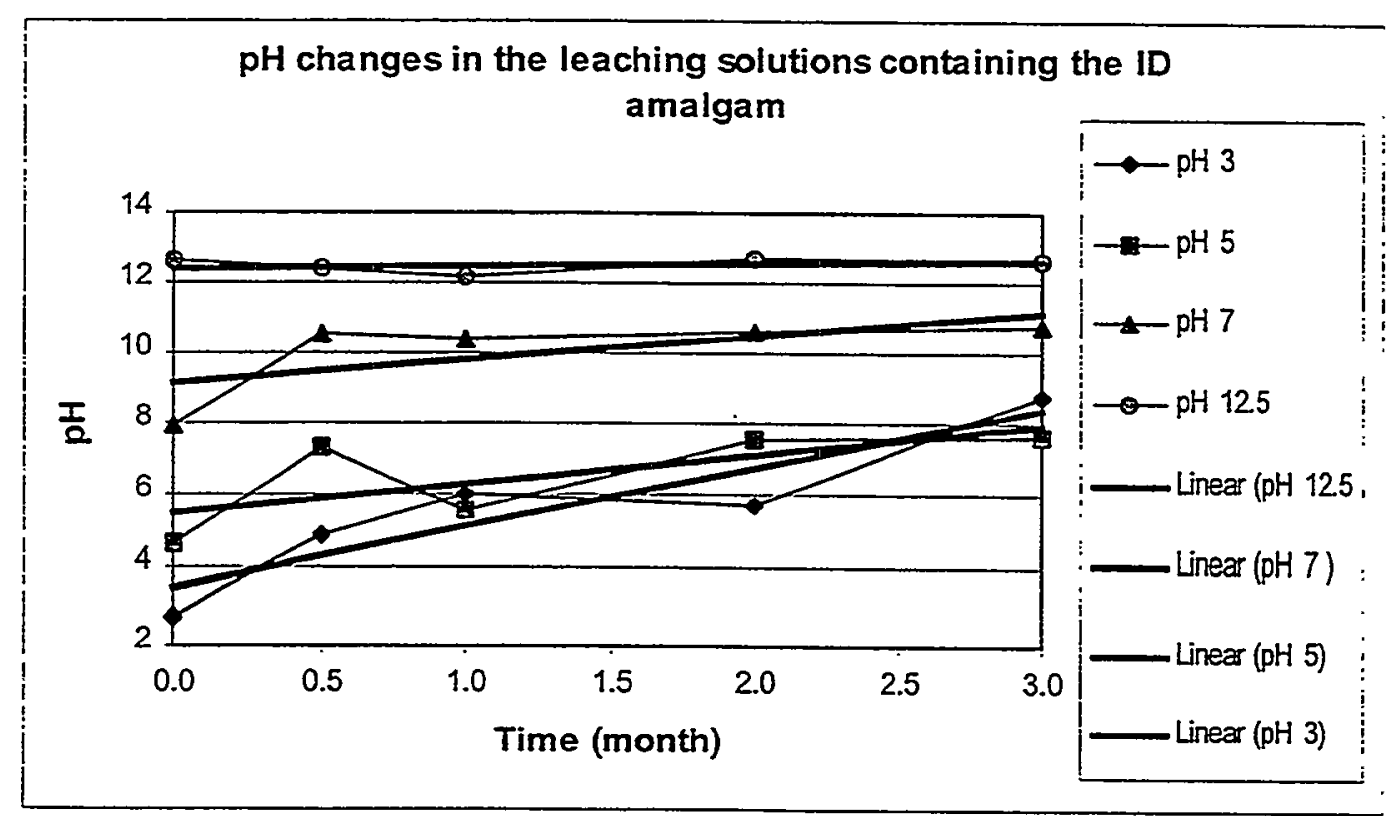

Fig. 8. Change in $\mathrm{pH}$ for the $\mathrm{m}$ amalgam series. 
mercury is $25 \mathrm{ppb}$; results for a few amalgams were found to be above this value, but nearly all the results obtained for mercury far exceeded this limit. Table 6 presents normalized data (in percent) of the leachability for each series relative to the leachability for the pure mercury standard at the same time interval. These changes are illustrated in Figs. 9-12.

The two processes behave very differently depending upon $\mathrm{pH}$. Acidic solutions appear to have a lesser deleterious effect upon the sulfur-based amalgams than the metal-based ones, which can release significant amounts of mercury (especially the ID series). Comparatively, the more basic solutions appear to be less aggressive on the metal-based amaigams than those solutions made with sulfur.

Table 5. Mercury leachability (micrograms per liter) measured for different amalgams

\begin{tabular}{|c|c|c|c|c|c|c|c|c|c|c|c|c|c|c|c|c|}
\hline $\mathrm{pH}$ & \multicolumn{4}{|c|}{ pH 3} & \multicolumn{4}{|c|}{ pH 5} & \multicolumn{4}{|c|}{$\mathrm{pH} 7$} & \multicolumn{4}{|c|}{$\mathrm{pH} 12.5$} \\
\hline Time & $2 w$ & $1 \mathrm{~m}$ & $2 \mathrm{~m}$ & $3 \mathrm{~m}$ & $2 w$ & $1 \mathrm{~m}$ & $2 \mathrm{~m}$ & $3 \mathrm{~m}$ & $2 \mathrm{w}$ & $1 \mathrm{~m}$ & $2 \mathrm{~m}$ & $3 \mathrm{~m}$ & $2 \mathrm{w}$ & $1 \mathrm{~m}$ & $2 \mathrm{~m}$ & $3 \mathrm{~m}$ \\
\hline $\mathrm{Hg}$ & 723 & 1337 & 537 & 4257 & 1368 & 3986 & 3111 & 7745 & 641 & 2739 & 1371 & 3666 & 5231 & 6594 & 4534 & 11259 \\
\hline LANL & 8.5 & 41 & ND & 5.9 & 38 & 54 & 20 & 10 & 8.2 & 7.4 & 52. & 21 & 8.6 & 5.9 & 12.8 & 12 \\
\hline FERN & 12 & 4.5 & 5.0 & 80 & 10 & 28 & 125 & 184 & 16 & 73 & 200 & 108 & 15 & 42 & 1223 & 264 \\
\hline OR & 16 & 76 & 4.5 & 62 & 13 & 109 & 34 & 213 & 4.5 & 21 & ND & 7.2 & 52 & 81 & 14.2 & 24 \\
\hline ID & 210 & 192 & 293 & 8.2 & 65 & 133 & 80 & 288 & 13 & 11 & ND & 9.4 & 33 & 70 & 406 & 110 \\
\hline
\end{tabular}

Table 6. Normalized (percent) mercury leachability for different amalgams

\begin{tabular}{|c|c|c|c|c|c|c|c|c|c|c|c|c|c|c|c|c|}
\hline $\mathrm{pH}$ & \multicolumn{4}{|c|}{$\mathrm{pH} 3$} & \multicolumn{4}{|c|}{ pH 5} & \multicolumn{4}{|c|}{$\mathrm{pH} 7$} & \multicolumn{4}{|c|}{ pH 12.5} \\
\hline Time & $2 w$ & $\operatorname{lm}$ & $2 \mathrm{~m}$ & $3 \mathrm{~m}$ & $2 w$ & $1 \mathrm{~m}$ & $2 m$ & $3 \mathrm{~m}$ & $2 w$ & $1 \mathrm{~m}$ & $2 \mathrm{~m}$ & $3 \mathrm{~m}$ & $2 w$ & $1 \mathrm{~m}$ & $2 \mathrm{~m}$ & $3 \mathrm{~m}$ \\
\hline $\mathrm{Hg}$ & 100 & 100 & 100 & 100 & 100 & 100 & 100 & 100 & 100 & 100 & 100 & 100 & 100 & 100 & 100 & 100 \\
\hline LANL & 1.2 & 3.1 & 0 & 0.1 & 2.8 & 1.4 & 0.6 & 0.1 & 1.3 & 0.3 & 3.8 & 0.6 & 0.2 & 0.1 & 0.3 & 0.1 \\
\hline FERN & 1.7 & 0.4 & 0.9 & 1.9 & 0.7 & 0.7 & 4.0 & 2.4 & 2.5 & 2.7 & 14.6 & 2.9 & 0.3 & 0.6 & 27.0 & 2.3 \\
\hline OR & 2.2 & 5.7 & 0.8 & 1.5 & 1.0 & 2.7 & 1.1 & 2.8 & 0.7 & 0.8 & 0 & 0.2 & 1.0 & 1.2 & 0.3 & 0.2 \\
\hline D & 29 & 14.4 & 54.5 & 0.2 & 4.7 & 3.3 & 2.6 & 3.7 & 2.0 & 0.4 & 0 & 0.2 & 0.6 & 1.1 & 9.0 & 1.0 \\
\hline
\end{tabular}




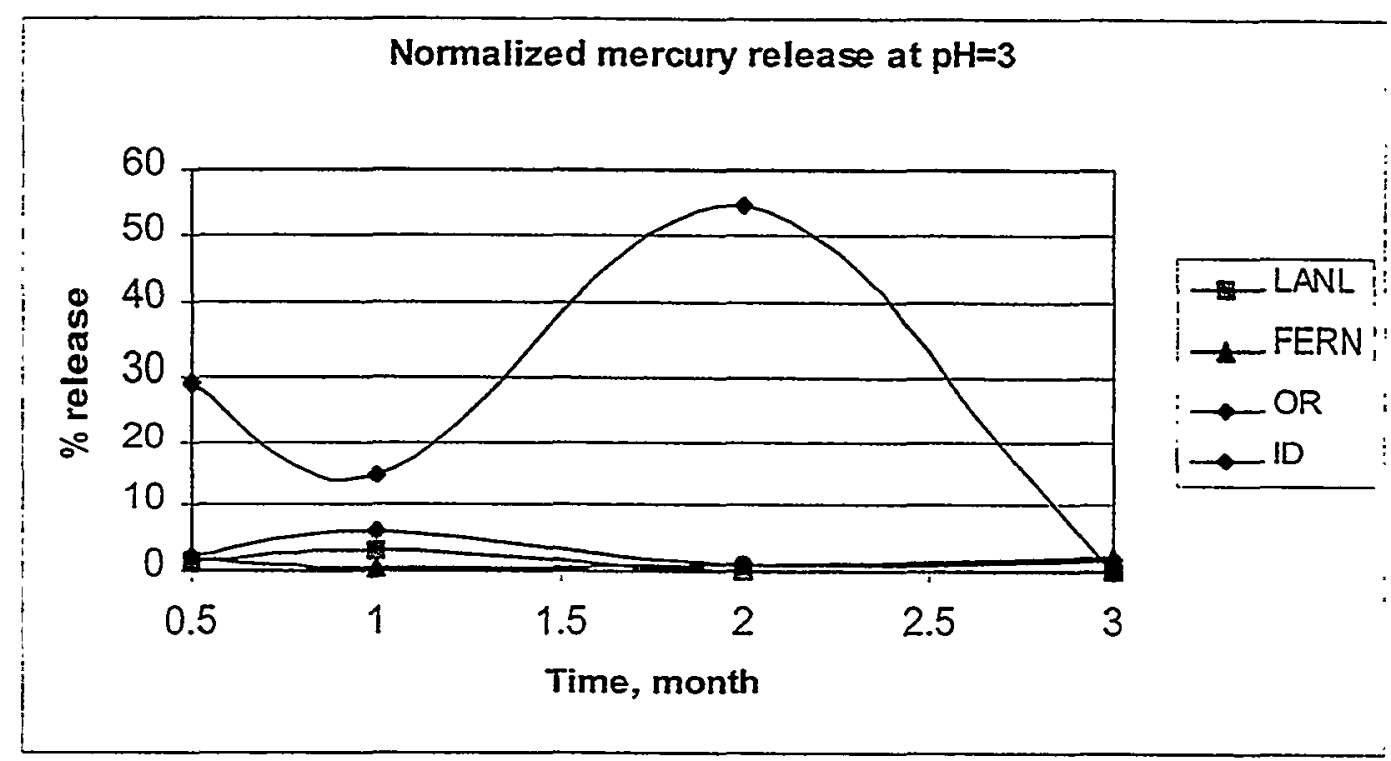

Fig. 9. Normalized mercury leachability for each type of amalgam at $\mathbf{p H}=3$.

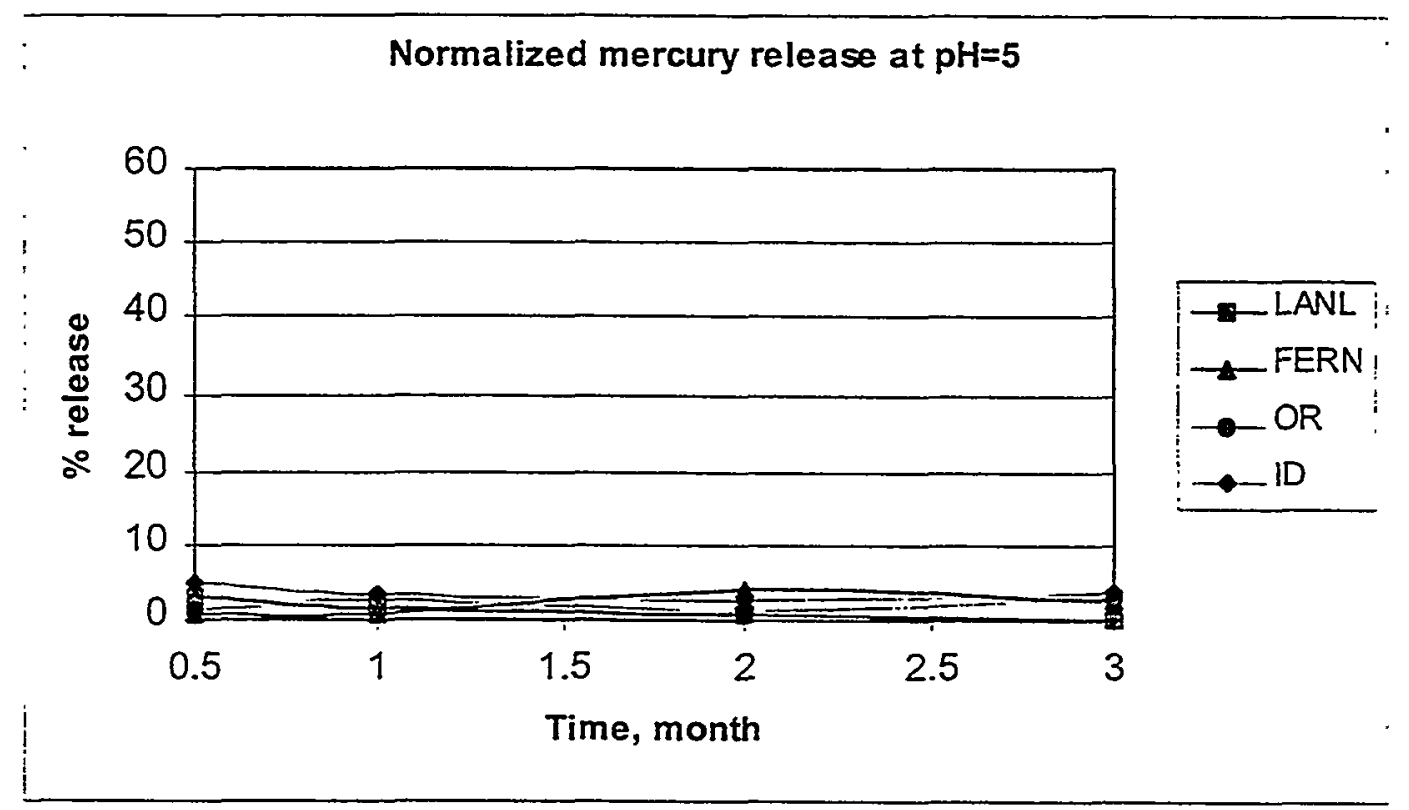

Fig. 10. Normalized mercury leachability for each type of amalgam at $p H=5$. 


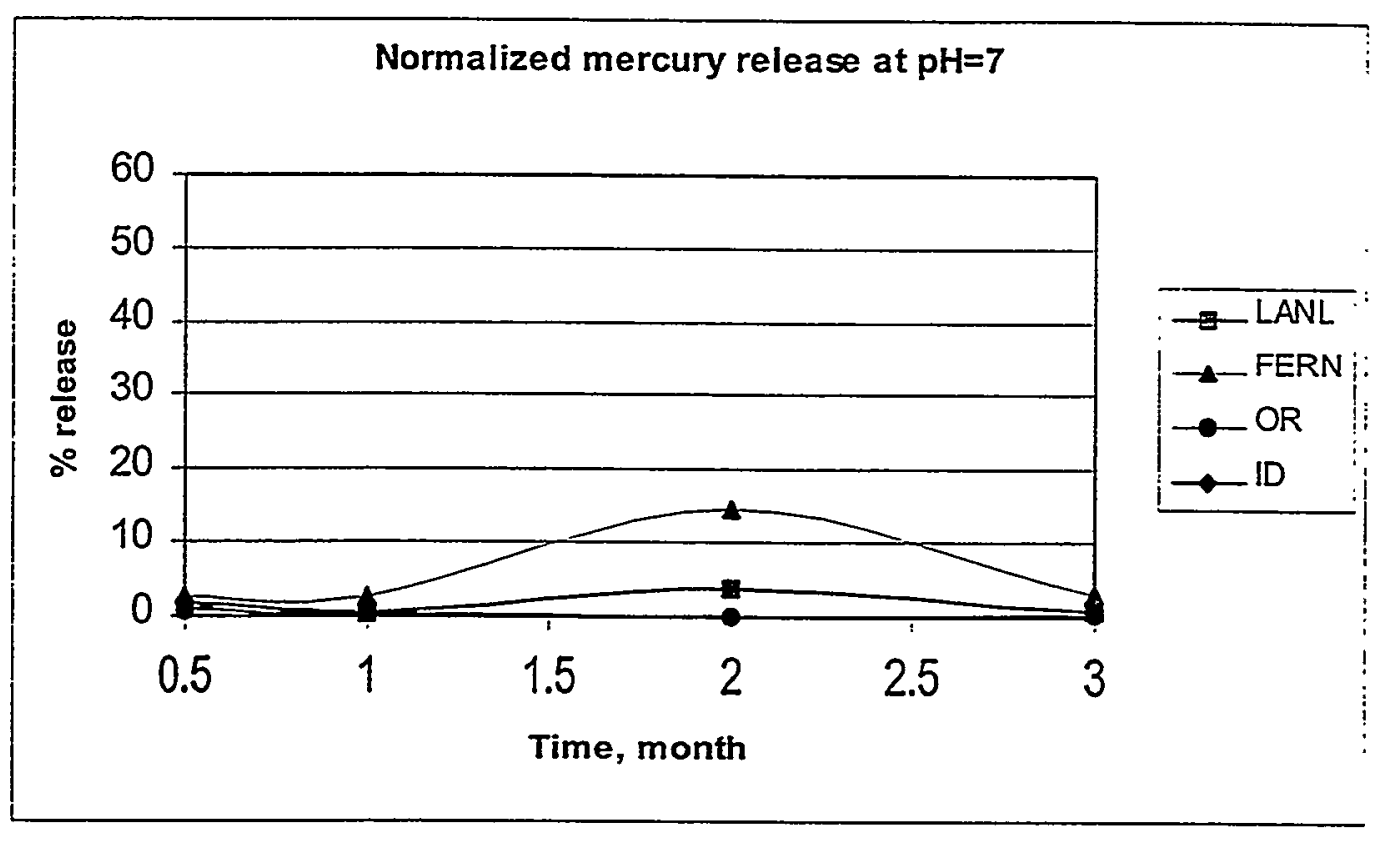

Fig. 11. Normalized mercury leachability for each type of amalgam at $\mathrm{pH}=7$.

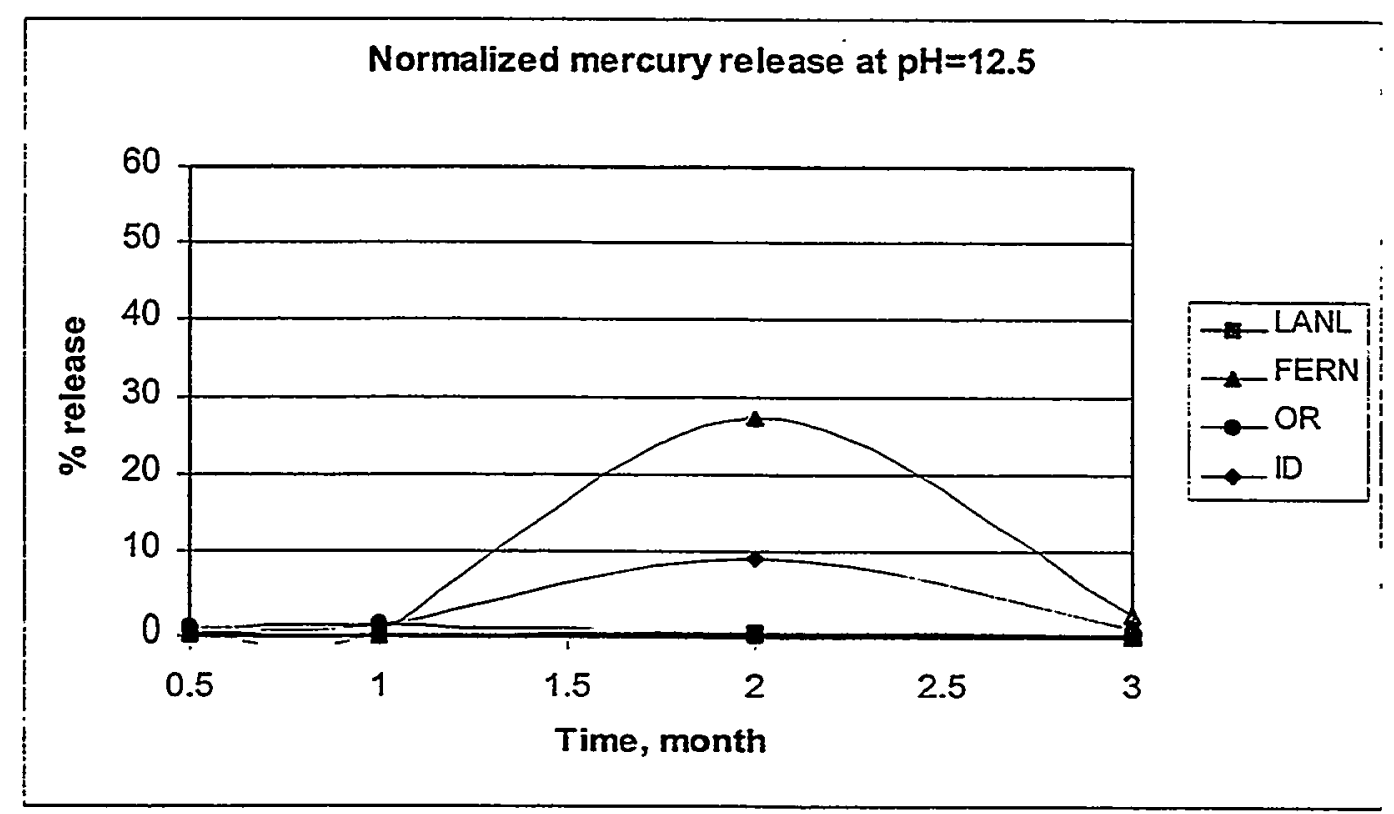

Fig. 12. Normalized mercury leachability for each type of amalgam at $\mathrm{pH}=12.5$. 


\subsection{METAL LEACHING RESULTS}

The leachates were also analyzed for trace metals by ICP-AES. Results obtained from the blank series are illustrated in Fig. 13 and provide an estimate of the contamination inherent in the experimental protocol followed - the high level of sodium found for a $\mathrm{pH}$ of 5 is caused by the presence of $\mathrm{NaOH}$ in TCLP fluid \#2; at a $\mathrm{pH}$ of 12.5 , the calcium hydroxide added for the preparation of the saturated $\mathrm{Ca}(\mathrm{OH})_{2}$ explains the high calcium content. Low concentrations of potassium, sodium, silicon, and zinc were found in this series. The mercury series (Fig. 14) shows that trace copper, silicon, and aluminum were present as contaminants in the mercury used for the experiments.

Data from the FERN series (Fig. 15) show that the following metals were found at low concentrations in the leaching solutions: aluminum, iron, magnesium, and strontium. The concentrations of metals leached were higher at low pH values than at higher ones. The concentration of calcium found in the leachate was high, around $2000 \mathrm{mg} / \mathrm{L}$. From the same process, the LANL series (Fig. 16) also presented higher concentrations of calcium than those in the blank; however, these concentrations were not as high as those observed in the FERN series. The concentrations of aluminum, iron, magnesium, potassium, sodium, and silicon present in the amalgams were higher than those found in the blank series.

Data from the OR series (Fig. 17) showed that small concentrations of aluminum, boron, iron, potassium, and silicon are also present in the leachates. At low $\mathrm{pH}$ values, high concentrations of zinc and magnesium were found in the leachates but were absent at neutral values or basic pHs. It is interesting to observe that in contrast to the sulfur-based amalgams, the metal-based type appears to consume calcium at high $\mathrm{pH}$. The ID amalgams (Fig. 18) released aluminum, boron, iron, potassium, and silicon. As in the OR series, magnesium and zinc were released at acidic pHs. The calcium release follows the same pattern as the OR series; concentrations at $\mathrm{pH}$ values of 12.5 were lower than those for the blank series. The sodium concentrations appear to be higher than those for the other series. 

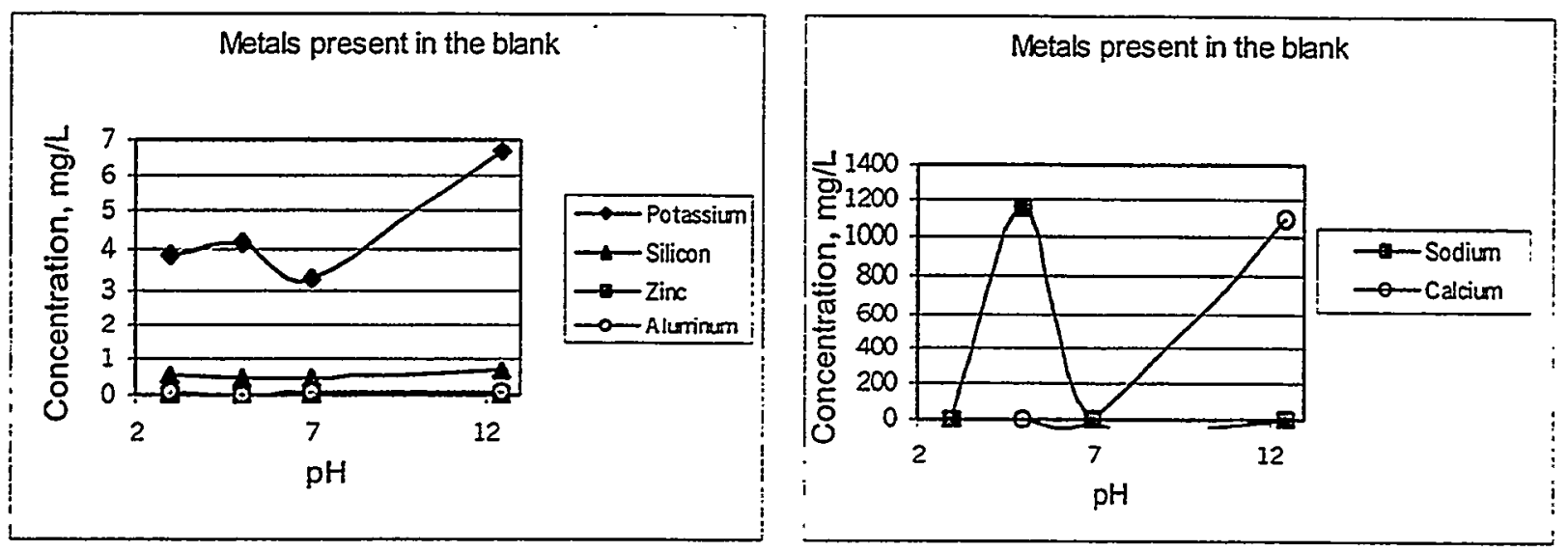

Fig. 13. Metals present in the blank.
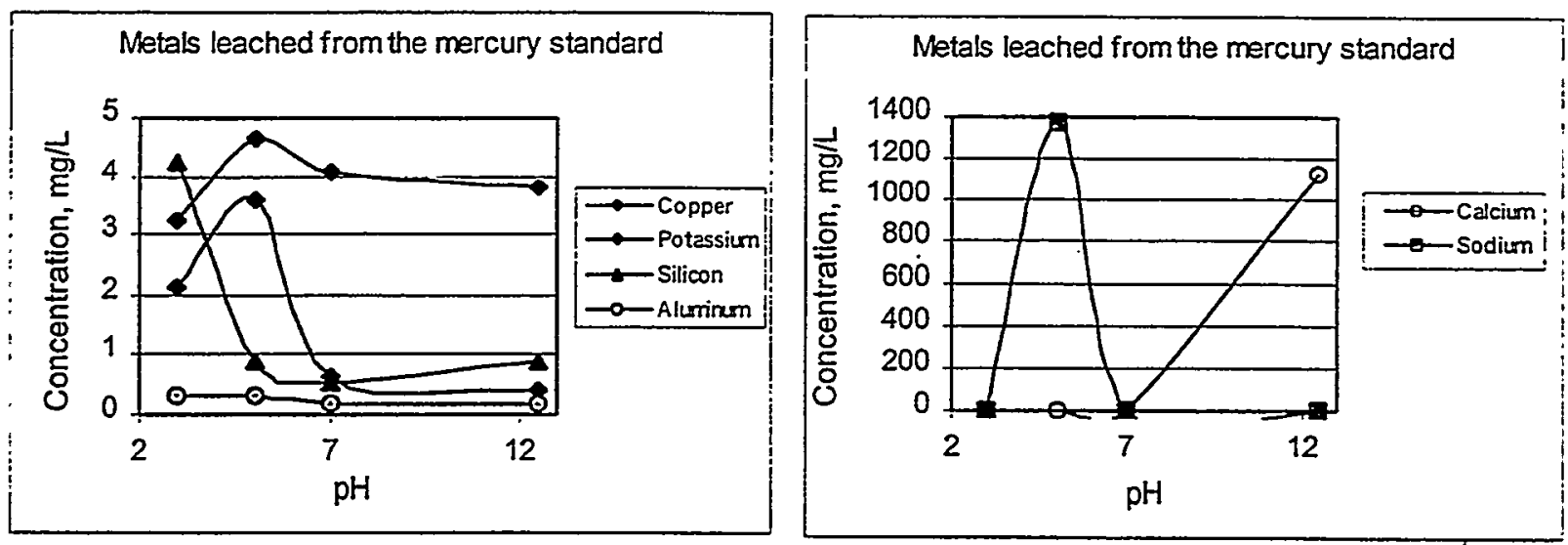

Fig. 14. Metals present in the leachates of the mercury standard.
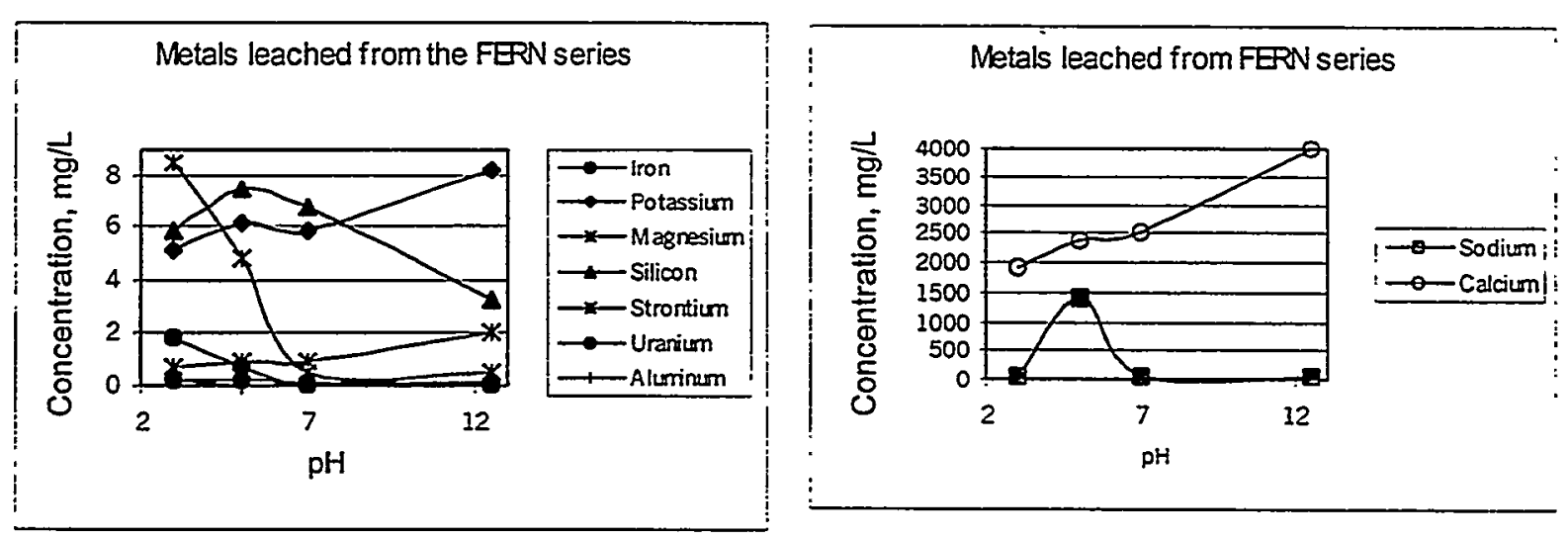

Fig. 15. Metals present in the leachates of the FERN amalgam. 

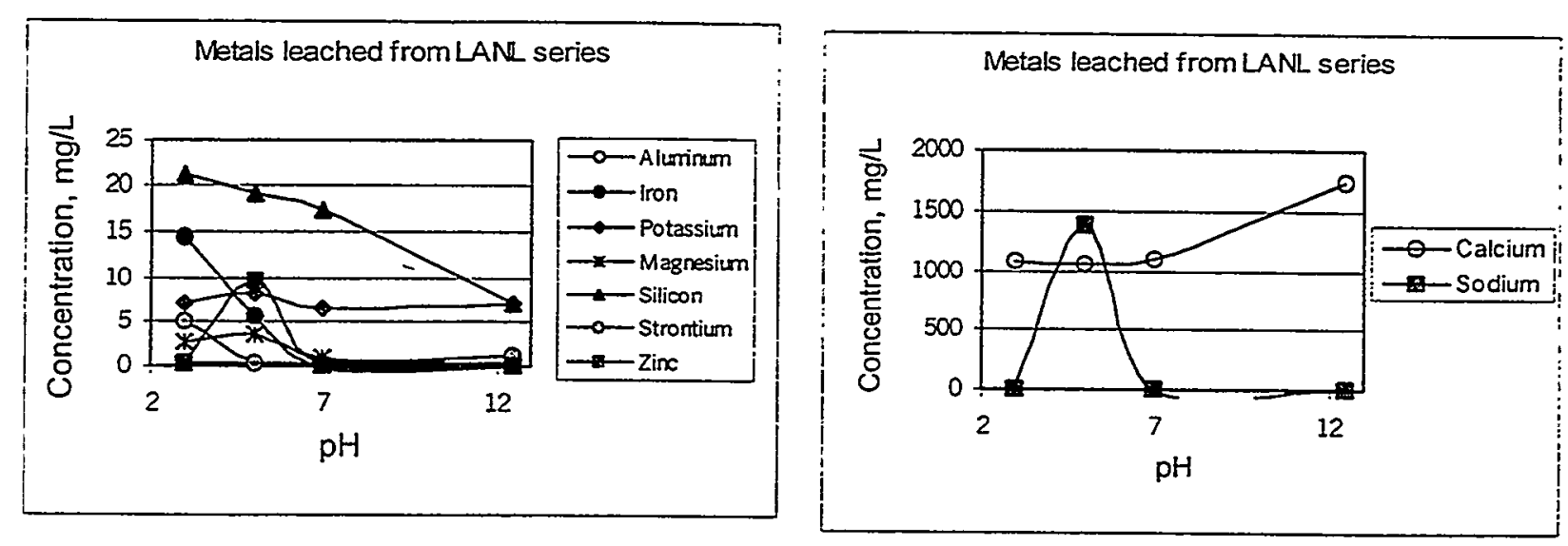

Fig. 16. Metals present in the leachates of the LANL amalgam.
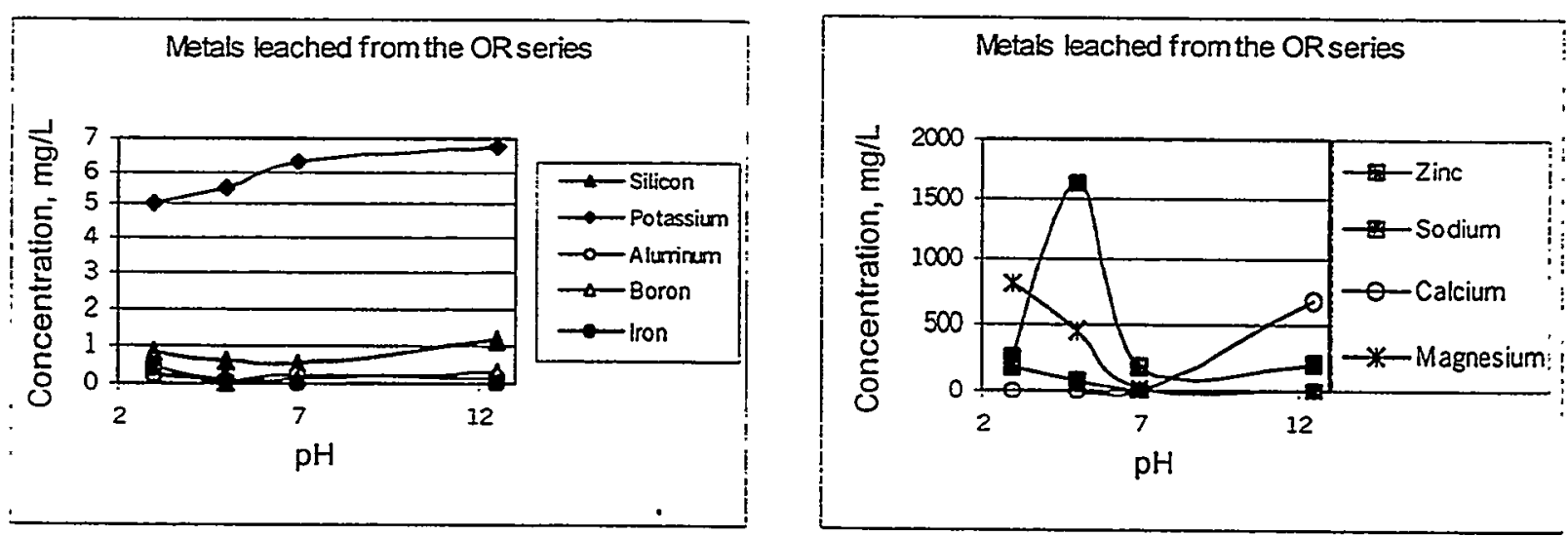

Fig. 17. Metals present in the leachates of the OR amalgam.
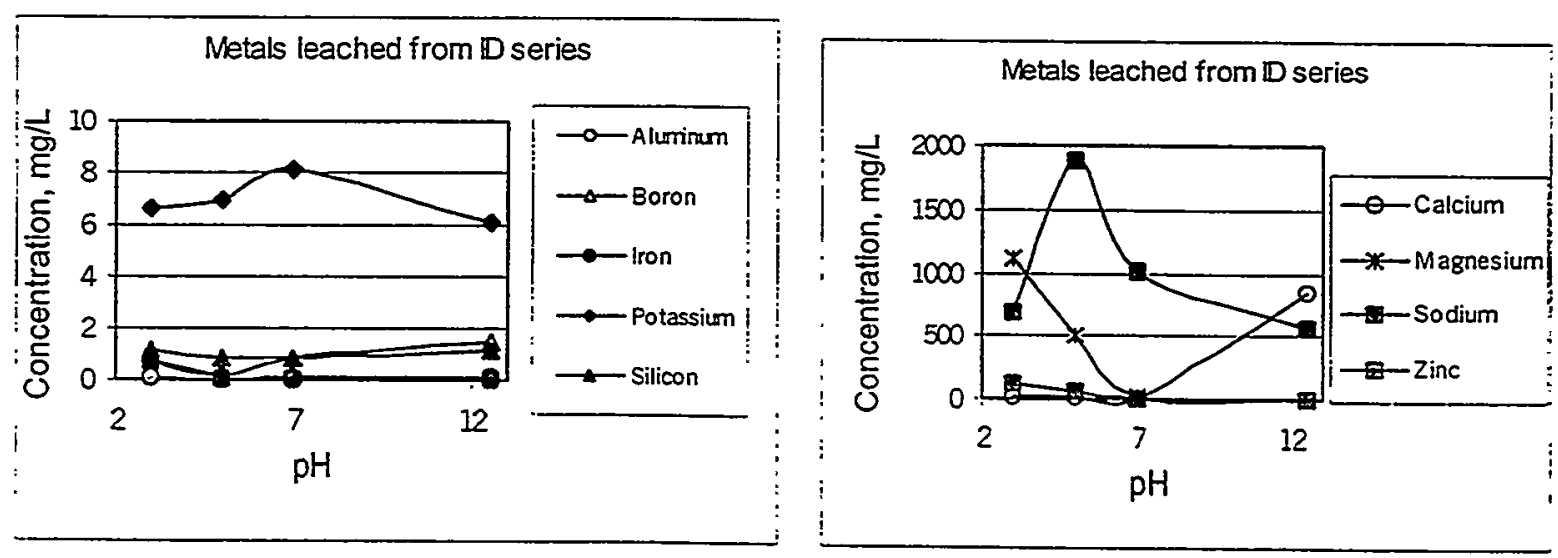

Fig. 18. Metals present in the leachates of the $\mathbf{I D}$ amalgam. 


\section{DISCUSSION OF RESULTS}

\subsection{AMALGAMATED MERCURY}

The acidic $\mathrm{pH}$ values were expected to have a more deleterious effect upon the amalgam when made with acid-reactive metals (zinc, aluminum, cadmium, copper) because of the generation of hydrogen that occurs at lower $\mathrm{pH}$ values. At higher $\mathrm{pH}$ values, hydrated oxides of mercury tend to form and are therefore expected to fare better. Amalgamated mercury did not perform as well as the sulfur-based mercuric sulfide. This may be explained by the well-known fact that mercury, once amalgamated with another metal such as zinc, copper, or aluminum, causes the metal to become very reactive in water and especially in acidic solutions. These metals will even slowly react with pure water, liberating hydrogen, and enter solution as the metal cation. This process is slow kinetically; however, when mercury amalgamates with the metal, the hydrogen potential of the metal reacting with water or acid is lowered considerably and becomes more reactive as a result. ${ }^{7}$ After all the metal dissolves, the elemental mercury remains behind. This reactivity with either acid or water is depicted in the following equations:

$$
\begin{gathered}
\mathrm{Hg}-\mathrm{M}^{*}+2 \mathrm{H}^{+} \rightarrow \mathrm{M}^{2+}+\mathrm{Hg}^{0}+\mathrm{H}_{2}(\mathrm{~g}) \uparrow \\
\mathrm{Hg}-\mathrm{M}+2 \mathrm{H}_{2} \mathrm{O} \rightarrow \mathrm{M}^{2+}+\mathrm{Hg}^{0}+\mathrm{H}_{2}(\mathrm{~g}) \uparrow+2 \mathrm{OH}^{-}
\end{gathered}
$$

Both reactions produce a rise in $\mathrm{pH}$, as illustrated by Figs. 7 and 8 . From the ICP data, it appears that zinc was likely used as an amalgamating metal. Because of the enhancement in reactivity of the metal toward water or acidic solutions, mercury amalgamation using such metals will result in the re-formation of free elemental mercury released to the environment over time, if the waste form is exposed to such conditions.

\footnotetext{
* Hg-M denotes a metal amalgam.
} 


\subsection{MERCURIC SULFIDE IMMOBILIZATION}

Mercury is found in nature as the very insoluble mineral cinnabar $(\mathrm{HgS})$ and is also known as mercuric sulfide. The sulfide is not reactive to any appreciable extent in water, with a solubility product $\left(\mathrm{K}_{\mathrm{sp}}\right)$ of only $10^{-15}$ for the black allotropic form. The sulfide is reactive only in acid and slowly reactive in oxygenated alkaline solution, where it can be oxidized to soluble mercuric sulfate or sometimes $\mathrm{HgOH}^{+}$. These first two reactions of mercuric sulfide can be depicted as follows:

$$
\mathrm{Hg}-\mathrm{M}^{*}+2 \mathrm{H}^{+} \rightarrow \mathrm{M}^{2}+\mathrm{Hg}^{0}+\mathrm{H}_{2}(\mathrm{~g}) \uparrow
$$

and

$$
\mathrm{HgS}+\mathrm{OH}^{-}+2 \mathrm{O}_{2}(\mathrm{~g}) \rightarrow \mathrm{Hg}(\mathrm{OH})^{+}+\mathrm{SO}_{4}^{2-}
$$

In Eq.(4), acid is consumed as mercury enters solution and the $\mathrm{pH}$ can be expected to rise, as shown in Figs. 5 and 6. Eventually, the mercury(II) cation can react with hydroxyl anion, when the $\mathrm{pH}$ rises sufficiently, and form moderately insolubie hydrates of mercury(I) oxide $(\mathrm{HgO})$.

In an alkaline solution, with air present above the solution, as was found in the experimental setup, the highly insoluble HgS can slowly be oxidized to more soluble mercuric sulfate. In Eq. (5), the hydroxyl anion is consumed, therefore causing a drop in $\mathrm{pH}$, as shown in Figs. 5 and 6. The reactions of $\mathrm{HgS}$ in an acid or base are numerous; therefore, the reactions shown in Eqs. (4) and (5) are probable but not the only ones possible. Eventually, mercury in neutral and alkaline solution will precipitate as oxide, as shown in Eq. (6):

$$
\mathrm{Hg}(\mathrm{OH})^{+}+\mathrm{OH}^{-} \rightarrow \mathrm{HgO} \downarrow+\mathrm{H}_{2} \mathrm{O}
$$

Since the reactivity of $\mathrm{HgS}$ in neutral water is far too slow to consider and the oxidation to soluble sulfate in alkaline solution is slow, sulfide is a good form to bind elemental mercury. 


\section{CONCLUSIONS}

Two different processes for treatment of radioactively contaminated mercury were evaluated: one process relied upon amalgamation with metals and the other depended on the formation of mercuric compounds with sulfur. In the set of experiments that evaluated the release of mercury vapor in the headspace as a function of temperature, the amalgams made with metals released as much mercury as the standard pure mercury added as a control. This observation was made at all three temperatures investigated, that is, 4,20 , and $60^{\circ} \mathrm{C}$. On the contrary, the compounds of mercury sulfide did not release mercury in the headspace. Even at $60^{\circ} \mathrm{C}$, the concentration of mercury present in the headspace of sulfide compounds did not exceed $1 \mathrm{mg} / \mathrm{m}^{3}$, while the metal-based amalgams could be as high as $260 \mathrm{mg} / \mathrm{m}^{3}$. This finding corroborates the results obtained by Gorin et al. (1) in their experimental work as well as those found in the literature?

When leagched in various solutions, the metal-based amalgams appeared to degrade more than the sulfur-based compounds, even though the duration of the tests was short ( 3 months). Some variability was found in the mercury leaching results. This could be caused by heterogeneity of the samples themselves; that is, all the mercury may not have reacted during the treatment. This was corroborated by the observation of a few tiny droplets of shiny mercury in the black FERN sulfur-based mercury compound. Another cause could be the presence in the leachate of small insoluble particulates of mercuric sulfide or compounds that were not captured by the filtration step-the $0.45-\mu \mathrm{m}$ filter-and were analyzed as ionic mercury from the leachate.

\section{REFERENCES}

1. A. H. Gorin, J. H. Leckey and L. E. Nulf, Final Disposal Options for Mercury/Uranium Mixed Wastes from the Oak Ridge Reservation, Y-DZ-1106, Oak Ridge Y-12 Plant, August 1994.

2. Mercury Amalgamation, Mixed Waste Focus Area, Technology Development Requirements Document, INEL/EXT-97-00314, Rev. 0, March 1997. 
3. D. M. Considine and G. D. Considine, eds., Encyclopedia of Chemistry, $4^{\text {th }}$ ed., Van Nostrand Reinhold, New York, 1984.

4. Code of Federal Regulations, Title 40, §796.1950, "Vapor pressure," Environmental Protection Agency.

5. American Society for Testing and Materials, "Standard Test Method for Vapor Pressure," ASTM E 1194-87, Philadelphia.

6. A. A. Kriger and R. R. Turner, Field Analysis of Mercury in Water, Sediment and Soil Using Static Headspace Analysis, CONF-940729-2, Oak Ridge National Laboratory, 1994.

7. P. C. L. Thorne and E. R. Roberts, Inorganic Chemistry, $5^{\text {th }}$ edition, Interscience Publishers, Inc., New York, 1949, p. 426. 
APPENDIX A

LEACHING TEST DATA 

Table A.1. Leaching results (milligrams per liter) obtained at 2 weeks - pH 3

\begin{tabular}{|c|c|c|c|c|c|c|c|c|c|c|c|c|c|c|c|c|c|c|}
\hline & Blk- & Blk-K & BIk-L & HG-B & HG-C & HG-11 & LANL-F & F LANL-5 & 5 LANL-6 & Fern-D & Fern-E & Fern-F & OR-A & OR-B & OR-8 & ID-A & ID-B & ID-C \\
\hline Weight(g) & & & & 15.84 & 14.32 & 6.64 & 7.63 & 9.80 & 6.49 & 6.63 & 7.90 & 11.44 & 20.36 & 25.53 & 26.87 & 7.37 & 7.17 & 6.46 \\
\hline Initlal pH & 2.96 & 2.96 & 2.96 & 2.96 & 2.96 & 2.96 & 2.96 & 2.96 & 2.96 & 2.96 & 2.96 & 2.96 & 2.96 & 2.96 & 2.96 & 2.96 & 2.96 & 2.96 \\
\hline Final pH & 2.87 & 2.85 & 2.89 & 2.87 & 2.88 & 2.86 & 3.28 & 3.45 & 3.38 & 3.38 & 3.42 & 3.44 & 5.22 & 5.30 & 6.96 & 5.00 & 4.74 & 4.78 \\
\hline Silver & $<0.00$ & $<0.003$ & $<0.003$ & $<0.005<$ & $<0.005$ & $<0.005$ & $<0.005$ & $<0.005$ & $<0.005$ & $<0.005$ & $<0.005$ & $<0.005$ & $<0.005$ & $<0.005$ & $<0.005$ & $<0.005$ & $<0.005$ & $<0.005$ \\
\hline Aluminum & 0.07 & 0.070 & 0.084 & 0.407 & 0.372 & 0.167 & 1.608 & 1.981 & 2.399 & 0.288 & 0.305 & 0.335 & 0.212 & 0.251 & 0.146 & 0.174 & 0.164 & 0.217 \\
\hline Arsenic & $<0.01$ & $<0.010$ & $<0.010$ & $<0.020<$ & $<0.020$ & $<0.020$ & $<0.020$ & $<0.020$ & $<0.020$ & $<0.020$ & $<0.020$ & $<0.020$ & $<0.020$ & $<0.020$ & $<0.020$ & $<0.020$ & $<0.020$ & $<0.020$ \\
\hline Boron & $<0.02$ & $<0.020$ & $<0.020$ & $<0.040<$ & $<0.040$ & $<0.040$ & $<0.040$ & $<0.040$ & $<0.040$ & $<0.040$ & $<0.040$ & $<0.040$ & 0.148 & 0.270 & 0.357 & 0.349 & 0.300 & 0.481 \\
\hline Barium & $<0.00$ & $<0.001$ & $<0.001$ & $<0.002<$ & $<0.002$ & $<0.002$ & 0.008 & 0.014 & 0.012 & 0.004 & 0.005 & 0.010 & $<0.002$ & $<0.002$ & $<0.002$ & 0.019 & 0.014 & 0.019 \\
\hline Beryllium & 0.00 & 0.002 & 0.002 & 0.002 & 0.002 & 0.003 & 0.003 & 0.003 & 0.004 & 0.003 & 0.003 & 0.004 & 0.004 & 0.004 & 0.004 & 0.003 & 0.003 & 0.003 \\
\hline Calcium & 0.04 & $<0.040$ & $<0.040$ & $0.204<$ & $<0.080$ & $<0.080$ & 541 & 832 & 658 & 974 & 1217 & 1591 & 8.59 & 7.50 & 8.99 & 15.69 & 8.03 & 16.21 \\
\hline Cadmium & $<0.00$ & $<0.001$ & $<0.001$ & $<0.002<$ & $<0.002$ & $<0.002$ & $<0.002$ & $<0.002$ & $<0.002$ & $<0.002$ & $<0.002$ & $<0.002$ & $<0.002$ & $<0.002$ & $<0.002$ & $<0.002$ & $<0.002$ & $<0.002$ \\
\hline Chromium & $<0.00$ & $<0.005$ & $<0.005$ & $<0.010<$ & $<0.010$ & $<0.010$ & $<0.010$ & 0.019 & 0.019 & $<0.010$ & $<0.010$ & $<0.010$ & $<0.010$ & $<0.010$ & $<0.010$ & $<0.010$ & $<0.010$ & $<0.010$ \\
\hline Copper & $<0.00$ & $<0.004$ & $<0.004$ & 4.164 & 3.695 & 1.362 & $<0.008$ & $<0.008$ & $<0.008$ & 0.014 & $<0.008$ & 0.015 & $<0.008$ & $<0.008$ & $<0.008$ & $<0.008$ & $<0.008$ & $<0.008$ \\
\hline Iron & $<0.05$ & & & $<0.100<$ & $<0.100$ & $<0.100$ & 6.111 & 10.292 & 6.675 & 1.115 & 1.528 & 1.873 & 0.843 & 1.294 & 1.481 & 0.797 & 0.404 & 0.654 \\
\hline Potassium & 4.28 & 5.368 & 11.178 & 3.998 & 4.807 & 1.974 & 10.211 & 6.598 & 3.747 & 4.135 & 4.040 & 14.264 & 6.794 & 6.443 & 6.700 & 4.104 & 6.276 & 15.45 \\
\hline Magnesium & $<0.02$ & $<0.020$ & $<0.020$ & $<0.040<$ & $<0.040$ & $<0.040$ & 0.978 & 1.709 & 1.383 & 4.083 & 4.811 & 6.805 & 823 & 968 & 1357 & 849 & 653 & 796 \\
\hline Manganese & $<0.00$ & $<0.001$ & $<0.001$ & $<0.002<$ & $<0.002$ & $<0.002$ & 0.052 & 0.129 & 0.082 & 0.018 & 0.025 & 0.029 & 0.052 & 0.068 & 0.058 & 0.028 & 0.025 & 0.024 \\
\hline Sodium & 0.69 & 0.077 & 0.073 & $<0.120<$ & $<0.120$ & 0.398 & 4.165 & 5.857 & 4.107 & 13.699 & 15.415 & 23.137 & 416 & 512 & 521 & 847 & 770 & 866 \\
\hline Nickel & $<0.00$ & $<0.004$ & & $<0.008<$ & $<0.008$ & $<0.008$ & 0.020 & 0.017 & 0.013 & $<0.008$ & $<0.008$ & $<0.008$ & $<0.008$ & $<0.008$ & $<0.008$ & $<0.008$ & $<0.008$ & $<0.008$ \\
\hline Lead & $<0.00$ & $<0.007$ & $<0.007$ & $<0.014<$ & $<0.014$ & $<0.014$ & $<0.014$ & $<0.014$ & $<0.014$ & $<0.014$ & $<0.014$ & $<0.014$ & $<0.014$ & $<0.014$ & $<0.014$ & $<0.014$ & $<0.014$ & $<0.014$ \\
\hline Selenium & 0.02 & 0.020 & 0.021 & 0.033 & 0.037 & 0.039 & $<0.020$ & $<0.020$ & $<0,020$ & $<0.020$ & 0.027 & 0.025 & $<0.020$ & $<0.020$ & $<0.020$ & $<0.020$ & $<0.020$ & $<0.020$ \\
\hline Antimony & $<0.01$ & $<0.010$ & $<0.010$ & $<0.020<$ & $<0.020$ & $<0.020$ & $<0.020$ & $<0.020$ & $<0.020$ & $<0.020$ & $<0.020$ & $<0.020$ & $<0.020$ & $<0.020$ & $<0.020$ & $<0.020$ & $<0.020$ & $<0.020$ \\
\hline Sillicon & 0.52 & 0.507 & 0.568 & 0.514 & 0.602 & 0.681 & 3.404 & 5.783 & 5.156 & 2.580 & 3.172 & 3.915 & 1.401 & 1.394 & 0.999 & 1.306 & 1.214 & 1.730 \\
\hline Strontium & $<0.00$ & $<0.001$ & $<0.001$ & $<0.002<$ & $<0.002$ & $<0.002$ & 0.190 & 0.321 & 0.222 & 0.310 & 0.393 & 0.589 & 0.024 & 0.021 & 0.023 & 0.070 & 0.046 & 0.066 \\
\hline Thorlum & $<0.13$ & $<0.130<$ & $<0.130$ & $<0.260<$ & $<0.260$ & $<0.260$ & $<0.260$ & $<0.260$ & $<0.260$ & $<0.260$ & $<0.260$ & $<0.260$ & $<0.260$ & $<0.260$ & $<0.260$ & $<0.260$ & $<0.260$ & $<0.260$ \\
\hline TItanium & 0.00 & 0.001 & 0.001 & $<0.002<$ & $<0.002$ & $<0.002$ & 0.004 & 0.005 & 0.004 & 0.005 & 0.007 & 0.009 & $<0.002$ & $<0.002$ & $<0.002$ & 0.002 & $<0.002$ & 0.003 \\
\hline Thallum & $<0.00$ & $<0.008<$ & $<0.008$ & $<0.016<$ & $<0.016$ & $<0.016$ & $<0.016$ & $<0.016$ & $<0.016$ & $<0.016$ & $<0.016$ & $<0.016$ & $<0.016$ & $<0.016$ & $<0.016$ & $<0.016$ & $<0.016$ & $<0.016$ \\
\hline Uranium & 0.09 & 0.074 & 0.070 & $<0.100<$ & $<0.100$. & $<0.100$ & $<0.100$ & $<0.100$ & $<0.100$ & $<0.100$ & $<0.100$ & $<0.100$ & $<0.100$ & $<0.100$ & $<0.100$ & $<0.100$ & $<0.100$ & $<0.100$ \\
\hline Vanadlum & $<0.01$ & $<0.010<$ & $<0.010$ & $<0.020<$ & $<0.020$ & $<0.020$ & $<0.020$ & 0.035 & 0.024 & $<0.020$ & $<0.020$ & 0.021 & $<0.020$ & $<0.020$ & $<0.020$ & $<0.020$ & $<0.020$ & $<0.020$ \\
\hline Zinc & 0.01 & 0.009 & 0.011 & 0.012 & 0.015 & 0.012 & 0.036 & 0.043 & 0.046 & 0.024 & 0.020 & 0.026 & 116.1 & 242.9 & 107.6 & 104.0 & 104.5 & 190.4 \\
\hline Zirconlum & $<0.01$ & $<0.010<$ & $<0.010$ & $<0.020<$ & $<0.020$ & $<0.020$ & $<0.020$ & 0.021 & 0.026 & 0.036 & $<0.020$ & 0.022 & 0.105 & 0.205 & 0.110 & 0.093 & 0.111 & 0.160 \\
\hline Mercury ${ }^{\mathrm{a}}$ & 0.20 & 0.121 & 0.136 & 555 & 665 & 949 & 9.12 & 8.28 & 8.24 & 8.7 & 10.8 & 17.5 & 17.8 & 20.4 & 9.940 & 318.0 & 173.0 & 139.0 \\
\hline
\end{tabular}

${ }^{a}$ Results in micrograms per liter. 
Table A.2. Leaching results (milligrams per liter) obtained at 2 weeks - pH 5

\begin{tabular}{|c|c|c|c|c|c|c|c|c|c|c|c|c|c|c|c|c|c|c|}
\hline & Blk- & Blk-H & Blk-I & HG-D & HG-E & HG-8 & LANL- & Lanl- & Lanl-2 & Fern- & Fern- & Fern-1 & OR.4 & OR-5 & OR-9 & ID-G & ID-H & ID-10 \\
\hline Welght(g) & & & & 19.15 & 18.64 & 8.22 & 11.12 & 14.41 & 9.76 & 5.99 & 8.67 & 16.76 & 17.40 & 37.46 & $\overline{37.18}$ & 7.11 & 7.43 & 6.85 \\
\hline Itlal pH & 5.00 & 5.00 & 5.00 & 5.00 & 5.00 & 5.00 & 5.00 & 5.00 & 5.00 & 5.00 & 5.00 & 5.00 & 5.00 & 5.00 & 5.00 & 5.00 & 5.00 & 5.00 \\
\hline FInal pH & 5.06 & 5.06 & 5.05 & 5.01 & 5.02 & 5.02 & 5.09 & 5.07 & 5.01 & 5.06 & 5.00 & 5.06 & 6.85 & 8.00 & 7.93 & 7.61 & 7.74 & 6.61 \\
\hline Silver & 0.003 & $<0.003$ & $<0.003$ & $<0.005$ & $<0.005$ & $<0.005$ & $<0.005$ & $<0.005$ & $<0.005$ & $<0.005$ & $<0.005$ & $<0.005$ & $<0.005$ & $<0.005$ & $<0.005$ & $<0.005$ & $<0.005$ & $<0.005$ \\
\hline Aluminum & $0.030<$ & $<0.030$ & $<0.030$ & 0.335 & 0.279 & $<0.060$ & $<0.060$ & $<0.060$ & $<0.060$ & $<0.060$ & $<0.060$ & $<0.060$ & $<0.060$ & $<0.060$ & $<0.060$ & $<0.060$ & $<0.060$ & $<0.060$ \\
\hline Arsenic & 0.010 & $<0.010$ & $<0.010$ & $<0.020$ & $<0.020$ & $<0.020$ & $<0.020$ & $<0.020$ & $<0.020$ & $<0.020$ & 0.020 & 0.026 & $<0.020$ & $<0.020$ & $<0.020$ & $<0.020$ & $<0.020$ & $<0.020$ \\
\hline Boron & 0.020 & $<0.020$ & $<0.020$ & $<0.040$ & $<0.040$ & $<0.040$ & $<0.040$ & $<0.040$ & $<0.040$ & $<0.040$ & $<0.040$ & $<0.040$ & $<0.040$ & $<0.040$ & $<0.040$ & $<0.040$ & $<0.040$ & $<0.040$ \\
\hline Barlum & 0.001 & 0.001 & $<0.001$ & $<0.002$ & $<0.002$ & $<0.002$ & 0.022 & 0.027 & 0.016 & 0.009 & 0.010 & 0.014 & 0.003 & 0.003 & 0.006 & 0.018 & 0.015 & 0.018 \\
\hline Beryllium & 0.002 & 0.002 & 0.002 & 0.002 & 0.003 & 0.003 & 0.003 & 0.003 & 0.003 & 0.004 & 0.004 & 0.004 & 0.004 & 0.004 & 0.004 & 0.003 & 0.003 & 0.004 \\
\hline Calclum & $<0.040$ & $<0.040$ & $<0.040$ & $<0.080$ & $<0.080$ & 0.644 & 939 & 1249 & 744 & 1266 & 1283 & 2238 & 6.716 & 12.007 & 10.653 & 12.091 & 9.221 & 10.094 \\
\hline Cadmium & $<0.001<$ & $<0.001$ & $<0.001$ & $<0.002$ & $<0.002$ & $<0.002$ & $<0.002$ & $<0.002$ & $<0.002$ & $<0.002$ & $<0.002$ & $<0.002$ & $<0.002$ & $<0.002$ & $<0.002$ & $<0.002$ & $<0.002$ & $<0.002$ \\
\hline Chromlum & $<0.005$ & $<0.005$ & $<0.005$ & $<0.010$ & $<0.010$ & $<0.010$ & $<0.010$ & $<0.010$ & $<0.010$ & $<0.010$ & $<0.010$ & $<0.010$ & $<0.010$ & $<0.010$ & $<0.010$ & $<0.010$ & $<0.010$ & $<0.010$ \\
\hline Copper & $<0.004$ & $<0.004$ & $<0.004$ & 4.863 & 4.776 & 1.707 & $<0.008$ & $<0.008$ & $<0.008$ & 0.017 & $<0.008$ & 0.017 & $<0.008$ & $<0.008$ & $<0.008$ & $<0.008$ & $<0.008$ & $<0.008$ \\
\hline Iron & $<0.050$ & $<0.050$ & $<0.050$ & $<0.100$ & $<0.100$ & $<0.100$ & 3.719 & 4.144 & 2.583 & 0.895 & 1.168 & 3.526 & $<0.100$ & 0.334 & 0.123 & $<0.100$ & $<0.100$ & $<0.100$ \\
\hline Potasslum & 4.967 & 5.735 & 5.700 & 6.025 & 5.733 & 6.581 & 8.075 & 7.988 & 12.239 & 4.200 & 3.480 & 6.009 & 3.816 & 12.164 & 11.774 & 5.762 & 9.999 & 21.232 \\
\hline Magneslum & $<0.020<$ & $<0.020$ & $<0.020$ & $<0.040$ & $<0.040$ & $<0.040$ & 1.514 & 1.903 & 0.961 & 3.813 & 5.639 & 10.729 & 324 & 615 & 465 & 380 & 377 & 386 \\
\hline Manganese & $<0.001<$ & $<0.001$ & $<0.001$ & $<0.002$ & $<0.002$ & $<0.002$ & 0.141 & 0.074 & 0.051 & 0.017 & 0.013 & 0.038 & 0.008 & 0.004 & $<0.002$ & 0.008 & 0.008 & 0.009 \\
\hline Sodium & 1243 & 1234 & 1229 & 1399 & 1405 & 1385 & 1373 & 1366 & 1397 & 1441 & 1507 & 1500 & 1932 & 1998 & 1932 & 2070 & 2032 & 1826 \\
\hline Nickel & $<0.004<$ & $<0.004$ & $<0.004$ & $<0.008$ & $<0.008$ & $<0.008$ & 0.014 & 0.019 & 0.013 & $<0.008$ & $<0.008$ & $<0.008$ & $<0.008$ & $<0.008$ & $<0.008$ & $<0.008$ & $<0.008$ & $<0.008$ \\
\hline Lead & $<0.007<$ & $<0.007$ & $<0.007$ & $<0.014$ & $<0.014$ & $<0.014$ & $<0.014$ & $<0.014$ & $<0.014$ & $<0.014$ & $<0.014$ & $<0.014$ & $<0.014$ & $<0.014$ & $<0.014$ & $<0.014$ & $<0.014$ & $<0.014$ \\
\hline Selenium & $<0.010<$ & $<0.010$ & $<0.010$ & $<0.020$ & $<0.020$ & $<0.020$ & $<0.020$ & $<0.020$ & $<0.020$ & $<0.020$ & $<0.020$ & $<0.020$ & $<0.020$ & $<0.020$ & $<0.020$ & $<0.020$ & $<0.020$ & $<0.020$ \\
\hline Antimony & $<0.010<$ & $<0.010$ & $<0.010$ & $<0.020$ & $<0.020$ & $<0.020$ & $<0.020$ & $<0.020$ & $<0.020$ & $<0.020$ & $<0.020$ & $<0.020$ & $<0.020$ & $<0.020$ & $<0.020$ & $<0.020$ & $<0.020$ & $<0.020$ \\
\hline Sillcon & 0.602 & 0.571 & 0.486 & 0.497 & 0.501 & 0.680 & 10.844 & 13.852 & 6.934 & 3.026 & 2.377 & 3.988 & 0.912 & 0.875 & 0.893 & 1.222 & 1.041 & 1.150 \\
\hline Strontlum & $<0.001<$ & $<0.001$ & $<0.001$ & $<0.002$ & $<0.002$ & $<0.002$ & 0.333 & 0.494 & 0.257 & 0.353 & 0.481 & 0.940 & 0.017 & 0.036 & 0.033 & 0.057 & 0.047 & 0.041 \\
\hline Thorlum & $<0.130<$ & $<0.130$ & $<0.130$ & $<0.260$ & $<0.260$ & $<0.260$ & $<0.260$ & $<0.260$ & $<0.260$ & $<0.260$ & $<0.260$ & $<0.260$ & $<0.260$ & $<0.260$ & $<0.260$ & $<0.260$ & $<0.260$ & $<0.260$ \\
\hline um & 0.001 & 0.001 & 0.001 & $<0.002$ & $<0.002$ & $<0.002$ & 0.006 & 0.007 & 0.005 & 0.008 & 0.007 & 0.011 & $<0.002$ & $<0.002$ & $<0.002$ & $<0.002$ & $<0.002$ & $<0.002$ \\
\hline Thallium & $<0.008<$ & $<0.008$ & $<0.008$ & $<0.016$ & $<0.016$ & $<0.016$ & $<0.016$ & $<0.016$ & $<0.016$ & $<0.016$ & $<0.016$ & $<0.016$ & 0.016 & $<0.016$ & $<0.016$ & $<0.016$ & $<0.016$ & $<0.016$ \\
\hline Uranlum & 0.067 & 0.067 & 0.056 & $<0.100$ & $<0.100$ & $<0.100$ & $<0.100$ & $<0.100$ & $<0.100$ & $<0.100$ & $<0.100$ & $<0.100$ & 0.100 & $<0.100$ & $<0.100$ & $<0.100$ & $<0.100$ & $<0.100$ \\
\hline Vanadlum & $<0.010<$ & $<0.010$ & $<0.010$ & $<0.020$ & $<0.020$ & $<0.020$ & 0.021 & 0.035 & $<0.020$ & $<0.020$ & $<0.020$ & $<0.020$ & $<0.020$ & $<0.020$ & $<0.020$ & $<0.020$ & $<0.020$ & $<0.020$ \\
\hline Zinc & 0.008 & 0.007 & 0.007 & 0.017 & 0.016 & 0.031 & 0.074 & 0.047 & 0.071 & 0.020 & 0.013 & 0.010 & 167.2 & 25.92 & 32.32 & 74.390 & 67.054 & 75.826 \\
\hline Zirconium & $0.011<$ & $<0.010$ & 0.014 & $<0.020$ & $<0.020$ & $<0.020$ & 0.036 & 0.037 & $<0.020$ & 0.025 & $<0.020$ & 0.029 & 0.164 & 0.051 & 0.051 & 0.074 & 0.074 & 0.087 \\
\hline Mercury" & 0.14 & 0.104 & 0.108 & 1423 & 1271 & 1411 & 50.8 & 54.6 & 9.1 & 10.7 & 11.4 & 8.1 & 13.1 & 19.90 & 5.790 & 8.100 & 10.90 & 176.0 \\
\hline
\end{tabular}

${ }^{a}$ Results in micrograms per liter. 
Table A.3. Leaching results (milligrams per liter) obtained at 2 weeks - pH 7

\begin{tabular}{|c|c|c|c|c|c|c|c|c|c|c|c|c|c|c|c|c|c|c|}
\hline & Blk-D & Blk-E & Blk-F & HG.F & HG-G & $\mathrm{HG} \cdot \mathrm{H}$ & Lanl- & Lanl-4 & Lanl-E & 1 Fern-J & Fern-K & Fern-L & OR-C & OR-7 & OR-17 & ID-E & ID-F & ID-1 \\
\hline Weight(g) & & & & 22.99 & 23.32 & 16.35 & 10.61 & 5.95 & & 8.16 & 11.8 & 12.05 & 20.77 & 26.3 & 5.66 & 5.16 & 5.26 & 5.80 \\
\hline Inittal pH & 7.87 & 7.87 & 7.87 & 7.87 & 7.87 & 7.87 & 7.87 & 7.87 & 7.87 & 7.87 & 7.87 & 7.87 & 7.87 & 7.87 & 7.87 & 7.87 & 7.87 & 7.87 \\
\hline Final pH & 7.54 & 6.70 & 6.34 & 7.35 & 7.40 & 7.08 & 6.35 & 4.80 & 6.35 & 8.66 & 8.80 & 9.77 & 10.45 & 10.3 & 10.70 & 10.49 & 10.4 & 10.59 \\
\hline Silver & $<0.003$ & $<0.003$ & $<0.003$ & $<0.005$ & $<0.005$ & $<0.005$ & $<0.005$ & $<0.005$ & $<0.005$ & $<0.005$ & $<0.005<$ & $<0.005$ & $<0.005$ & $<0.005<$ & $=0.005$ & $=0.005$ & $<0.005$ & $<0.005$ \\
\hline Aluminum & 0.068 & 0.080 & 0.070 & 0.144 & 0.154 & 0.158 & 0.124 & 0.126 & 0.129 & 0.215 & 0.168 & 0.219 & 0.119 & 0.145 & 0.201 & 0.109 & 0.099 & 0.123 \\
\hline Arsenic & $<0.010$ & $<0.010<$ & $<0.010$ & $<0.020$ & $<0.020$ & $<0.020$ & $<0.020$ & $<0.020$ & $<0.020$ & $<0.020$ & $<0.020<$ & $<0.020$ & $<0.020$ & $<0.020<$ & $<0.020$ & $<0.020$ & $<0.020<$ & $<0.020$ \\
\hline Boron & $<0.020$ & $<0.020<$ & $<0.020$ & $<0.040$ & $<0.040$ & $<0.040$ & $<0.040$ & $<0.040$ & $<0.040$ & $<0.040$ & $<0.040<$ & $<0.040$ & 0.143 & $0: 107$ & 0.097 & 0.400 & 0.308 & 0.382 \\
\hline Barlum & $<0.001$ & $<0.001$ & $<0.001$ & $<0.002$ & $<0.002$ & $<0.002$ & 0.015 & 0.009 & 0.011 & 0.006 & 0.007 & 0.010 & $<0.002$ & $<0.002<$ & $=0.002$ & 0.011 & 0.010 & 0.009 \\
\hline Beryllium & 0.002 & 0.001 & 0.002 & 0.002 & 0.003 & 0.003 & 0.003 & 0.003 & 0.003 & 0.003 & 0.004 & 0.004 & 0.004 & 0.004 & 0.004 & 0.003 & 0.003 & 0.004 \\
\hline Calclum & 0.479 & 0.047 & 0.053 & $<0.080$ & $<0.080$ & $<0.080$ & 860 & 511 & 565 & 1244 & 1588 & 1811 & 2.830 & 5.883 & 0.990 & 4.521 & 5.565 & 3.072 \\
\hline Cadmium & $<0.001$ & $<0.001<$ & $<0.001$ & $<0.002$ & $<0.002$ & $<0.002$ & $<0.002$ & $<0.002$ & $<0.002$ & 0.002 & $<0.002<$ & $<0.002$ & $<0.002$ & $<0.002<$ & $<0.002$ & 0.002 & $<0.002$ & $<0.002$ \\
\hline Chromlum & $<0.005$ & $<0.005$ & $<0.005$ & $<0.010$ & $<0.010$ & $<0.010$ & $<0.010$ & $<0.010$ & $<0.010$ & 0.010 & $<0.010<$ & $<0.010$ & $<0.010$ & $<0.010<$ & 0.010 & $<0.010$ & $<0.010<$ & $<0.010$ \\
\hline opper & $<0.004$ & 0.017 & $<0.004$ & 0.268 & 0.426 & 0.655 & $<0.008$ & $<0.008$ & $<0.008$ & 0.008 & $<0.008$ & 0.021 & 0.008 & $<0.008<$ & $=0.008$ & $<0.008$ & $<0.008<$ & $<0.008$ \\
\hline Iron & $<0.050$ & $<0.050<$ & $<0.050$ & $<0.100$ & $<0.100$ & $<0.100$ & $<0.100$ & $<0.100$ & $<0.100$ & $<0.100$ & $<0.100<$ & $=0.100$ & $<0.100$ & $<0.100<$ & $=0.100$ & $<0.100$ & $<0.100<$ & $<0.100$ \\
\hline Potas & 4.238 & 4.309 & 3.825 & 5.419 & 4.208 & 4.625 & 5.516 & 10.726 & 5.646 & 5.484 & 4.010 & 3.659 & 5.277 & 6.232 & 4.101 & 6.72 & 10.66 & 7.34 \\
\hline Magnesium & $<0.020$ & $<0.020<$ & $<0.020$ & $<0.040$ & $<0.040$ & $<0.040$ & 0.710 & 0.479 & 0.535 & 0.166 & 0.288 & 0.218 & 45.31 & 89.89 & 20.89 & 25.62 & 32.05 & 19.08 \\
\hline Manganese & $<0.001$ & $<0.001<$ & $<0.001$ & $<0.002$ & $<0.002$ & $<0.002$ & 0.005 & 0.002 & 0.003 & 0.002 & $<0.002<$ & $=0.002$ & $<0.002$ & $<0.002<$ & $=0.002$ & 0.002 & $<0.002<$ & $<0.002$ \\
\hline Sodlum & $<0.060$ & 0.069 & $<0.060$ & 0.457 & $<0.120$ & $<0.120$ & 5.743 & 3.878 & 3.877 & 19.34 & 26.12 & 27.02 & 400 & 464 & 103 & 530 & 711 & 696 \\
\hline Nickel & $<0.004$ & $<0.004<$ & $<0.004$ & $<0.008$ & $<0.008$ & $<0.008$ & $<0.008$ & $<0.008$ & $<0.008$ & .008 & $<0.008<$ & $=0.008$ & $k 0.008$ & $<0.008<$ & $=0.008$ & $<0.008$ & $<0.008<$ & $<0.008$ \\
\hline Lead & $<0.007$ & $<0.007<$ & $<0.007$ & $<0.014$ & $<0.014$ & $<0.014$ & $<0.014$ & $<0.014$ & $<0.014$ & $<0.014$ & $<0.014<$ & 0.014 & $=0.014$ & $<0.014<$ & $=0.014$ & $=0.014$ & $<0.014<$ & 0.014 \\
\hline Selenlum & $<0.010$ & 0.012 & $<0.010$ & 0.025 & 0.026 & 0.022 & $<0.020$ & $<0.020$ & $<0.020$ & $<0.020$ & $<0.020<$ & $\div 0.020$ & $<0.020$ & $<0.020$ & 0.029 & $<0.020$ & $<0.020<$ & $<0.020$ \\
\hline Antimony & $<0.010$ & $<0.010<$ & $<0.010$ & $<0.020$ & $<0.020$ & $<0.020$ & $<0.020$ & $<0.020$ & $<0.020$ & $<0.020$ & $<0.020<$ & 0.020 & $<0.020$ & $<0.020<$ & $=0.020$ & $<0.020$ & $<0.020<$ & $<0.020$ \\
\hline Sillicon & 0.461 & 0.449 & 0.474 & 0.511 & 0.498 & 0.561 & 9.671 & 7.151 & 9.513 & 3.543 & 4.934 & 4.885 & 0.881 & 0.878 & 0.484 & 0.890 & 0.898 & 0.974 \\
\hline Strontlum & $<0.001$ & $<0.001<$ & $<0.001$ & $<0.002$ & $<0.002$ & $<0.002$ & 0.325 & 0.166 & 0.188 & 0.430 & 0.580 & 0.682 & 0.006 & 0.015 & 0.003 & 0.024 & 0.030 & 0.021 \\
\hline Thorium & $<0.130$ & $<0.130<$ & $<0.130$ & $<0.260$ & $<0.260$ & $<0.260$ & $<0.260$ & $<0.260$ & $<0.260$ & $<0.260$ & $<0.260<$ & $=0.260$ & $<0.260$ & $<0.260<$ & $=0.260$ & $<0.260$ & $<0.260<$ & $=0.260$ \\
\hline Titanium & 0.001 & $<0.001$ & 0.001 & $<0.002$ & $<0.002$ & $<0.002$ & 0.005 & 0.003 & 0.004 & 0.006 & 0.009 & 0.010 & $<0.002$ & $<0.002<$ & 0.002 & $<0.002$ & $<0.002<$ & 0.002 \\
\hline Thalllum & $<0.008$ & $<0.008<$ & $<0.008$ & $<0.016$ & $<0.016$ & $<0.016$ & $<0.016$ & $<0.016$ & $<0.016$ & 0.016 & $<0.016<$ & 0.016 & $<0.016$ & $<0.016<$ & $=0.016$ & $<0.016$ & $<0.016<$ & 0.016 \\
\hline Uranium & 0.094 & $<0.050$ & 0.080 & $<0.100$ & $<0.100$ & $<0.100$ & $<0.100$ & $<0.100$ & $<0.100$ & 0.100 & $<0.100<$ & $=0.100$ & $<0.100$ & $<0.100<$ & $=0.100$ & $<0.100$ & $<0.100<$ & 0.100 \\
\hline Vanadium & $<0.010$ & $<0.010<$ & $<0.010$ & $<0.020$ & $<0.020$ & $<0.020$ & $<0.020$ & $<0.020$ & $<0.020$ & 0.020 & $<0.020<$ & $=0.020$ & $<0.020$ & $<0.020<$ & $=0.020$ & 0.020 & $<0.020<$ & 0.020 \\
\hline Zinc & 0.014 & $0.007<$ & $<0.005$ & $<0.010$ & $<0.010$ & $<0.010$ & $<0.010$ & $<0.010$ & 0.011 & 0.010 & $<0.010<$ & 0.010 & 0.077 & 0.104 & 0.167 & 0.056 & 0.054 & 0.078 \\
\hline Zirconlum & $<0.010$ & $<0.010<$ & $<0.010$ & $<0.020$ & $<0.020$ & $<0.020$ & 0.031 & 0.021 & 0.021 & 0.034 & $<0.020$ & 0.023 & 0.020 & $<0.020<$ & $=0.020$ & $<0.020$ & $<0.020<$ & 0.020 \\
\hline Mercury" & 0.081 & 0.05 & 0.141 & 630 & 343 & 950 & 9.05 & 7.86 & 7.68 & 12.7 & 2.24 & 18.6 & 9.03 & 1.60 & 2.760 & 19.0 & 13.3 & 7.860 \\
\hline
\end{tabular}

${ }^{\mathrm{a}}$ Results in micrograms per liter. 
Table A.4. Leaching results (milligrams per liter) obtained at 2 weeks - pH 12.5

\begin{tabular}{|c|c|c|c|c|c|c|c|c|c|c|c|c|c|c|c|c|c|c|}
\hline & B!k-A & B|k-B & Blk-C & HG- & HG-1 & HG-12 & 2 Lanl-A & Lanl-H & Lanl-7 & Fern-A & Fem-B & Fern-C & OR-1 & OR-2 & OR-18 & ID.D & ID- & ID- \\
\hline Welght(g) & & & & 11.7 & 4.92 & 5.54 & 11.06 & 7.51 & 8.66 & 7.90 & 8.68 & 6.59 & 21.0 & 22.52 & 5.39 & 4.33 & 6.85 & 5.33 \\
\hline nitlal pH & 12.53 & 12.53 & 12.53 & 12.5 & 12.53 & 12.5 & 12.53 & 12.53 & 12.53 & 12.53 & 12.53 & 12.53 & 12.5 & 12.53 & 12.53 & 12.5 & 12.53 & 12.53 \\
\hline nal pH & 2.78 & 12.78 & $12.74^{\circ}$ & 12.7 & 12.73 & 12.7 & 12.67 & 12.48 & 12.65 & 12.59 & 12.55 & 12.61 & 12.4 & 12.37 & 12.71 & 12.4 & 12.34 & 12.48 \\
\hline Iver & $<0.003$ & $<0.003$ & $<0.003$ & 0.024 & 0.005 & $<0.005$ & $<0.005$ & $<0.005$ & $<0.005$ & 0.005 & $<0.005$ & $<0.005$ & $<0.005$ & $<0.005$ & $<0.005$ & $<0.005$ & 0.005 & $<0.005$ \\
\hline Alumlnum & 0.070 & 0.084 & 0.081 & 0.249 & 0.171 & 0.194 & 0.128 & 0.141 & 0.127 & 0.175 & 0.176 & 0.158 & 0.163 & 0.170 & 0.210 & 0.111 & 0.141 & 0.113 \\
\hline ic & $<0.010$ & $<0.010$ & $<0.010$ & $<0.020$ & 0.021 & $<0.020$ & $<0.020$ & $<0.020$ & $<0.020$ & 0.022 & 0.022 & 0.022 & $<0.020$ & $<0.020$ & $<0.020$ & $<0.020<$ & $<0.020$ & $<0.020$ \\
\hline oron & .020 & $<0.020$ & $<0.020$ & $<0.040<$ & $<0.040$ & $<0.040$ & $<0.040$ & $<0.040$ & $<0.040$ & $<0.040$ & $<0.040$ & $<0.040$ & 0.425 & 0.613 & 0.185 & 1.298 & 1.378 & 1.709 \\
\hline & 016 & 0.016 & 0.016 & 0.016 & 0.032 & 0.016 & 0.041 & 0.032 & 0.037 & 0.021 & 0.024 & 0.020 & 0.015 & 0.016 & 0.016 & 0.026 & 0.030 & 0.026 \\
\hline lum & 0.002 & 0.002 & 0.002 & 0.002 & 0.003 & 0.003 & 0.003 & 0.003 & 0.003 & 0.004 & 0.004 & 0.003 & 0.004 & 0.004 & 0.004 & 0.003 & 0.004 & 0.004 \\
\hline & 1031 & 1024 & 1020 & 968 & 2024 & 986 & 1946 & 1402 & 1611 & 2105 & 2149 & 1801 & 1031 & 803 & 1132 & 707 & 656 & 765 \\
\hline lum & $<0.001$ & $<0.001$ & $<0.001$ & $<0.002<$ & $<0.002$ & $<0.002$ & $<0.002$ & $<0.002$ & $<0.002$ & $<0.002$ & $<0.002$ & $<0.002$ & $<0.002$ & $<0.002$ & $<0.002$ & $<0.002<$ & $<0.002$ & $<0.002$ \\
\hline Iromlum & 0.032 & 0.030 & 0.030 & 0.027 & 0.060 & 0.028 & $<0.010$ & $<0.010$ & 0.018 & $<0.010$ & $<0.010$ & 0.011 & $<0.010$ & $<0.010$ & 0.011 & $<0.010<$ & $<0.010$ & 0.011 \\
\hline ppper & $<0.004$ & $<0.004$ & $<0.004$ & 1.093 & 0.856 & 0.450 & $<0.008$ & $<0.008$ & $<0.008$ & 0.042 & 0.018 & 0.021 & 0.008 & 0.008 & $<0.008$ & $<0.008$ & 0.018 & 0.086 \\
\hline ron & $<0.050$ & $<0.050$ & $<0.050$ & $<0.100<$ & $<0.100$ & $<0.100$ & $<0.100$ & $<0.100$ & $<0.100$ & $<0.100$ & $<0.100$ & $<0.100$ & $<0.100$ & $<0.100$ & $<0.100$ & $<0.100<$ & $<0.100$ & $<0.100$ \\
\hline tas & 4.687 & 22.813 & 6.959 & 4.305 & 12.560 & 4.579 & 6.176 & & .470 & & & 864 & 0.89 & 6.601 & 4.777 & 4.177 & 11.684 & 9.100 \\
\hline slum & $<0.020$ & $<0.020$ & $<0.020$ & $<0.040<$ & $<0.040$ & $<0.040$ & 0.045 & $<0.040$ & $<0.040$ & 0.057 & 0.055 & $<0.040$ & 0.072 & $<0.040$ & $<0.040$ & 0.169 & 0.074 & $<0.040$ \\
\hline nese & 001 & $<0.001$ & $<0.001$ & 002 & $<0.002$ & $<0.002$ & $<0.002$ & $<0.002$ & $<0.002$ & 0.002 & $<0.0$ & $<0.002$ & $<0.002$ & $<0.002$ & $<0.002$ & $<0.002<$ & $<0.002$ & $<0.002$ \\
\hline & 0.938 & 0.945 & 0.930 & 0.869 & 2.051 & 1.087 & 6.647 & 5.497 & 6.024 & 16.18 & 19.56 & 13.92 & 361 & 461 & 113 & 638 & 629 & 652 \\
\hline ckel & $<0.004$ & $<0.004$ & $<0.004$ & $<0.008<$ & $<0.008$ & $<0.008$ & $<0.008$ & $<0.008$ & $<0.008$ & $<0.008$ & $<0.008$ & $<0.008$ & $<0.008$ & $<0.008$ & $<0.008$ & $<0.008<$ & $<0.008$ & $<0.008$ \\
\hline ad & .007 & $<0.007$ & $<0.007$ & 0.014 & $=0.014$ & $<0.014$ & $<0.014$ & $<0.014$ & $<0.014$ & 0.014 & $<0.014$ & $<0.014$ & $<0.014$ & $<0.014$ & $<0.014$ & $<0.014<$ & $<0.014$ & $<0.014$ \\
\hline lum & $<0.010$ & $<0.010$ & $<0.010$ & $<0.020<$ & $=0.020$ & $<0.020$ & $<0.020$ & $<0.020$ & $<0.020$ & 20 & $<0.020$ & $<0.020$ & $<0.020$ & $<0.020$ & $<0.020$ & $<0.020<$ & $<0.020$ & $<0.020$ \\
\hline nony & 0.010 & $<0.010$ & $<0.010$ & $<0.020<$ & $=0.020$ & $<0.020$ & $<0.020$ & $<0.020$ & $<0.020$ & $<0.020$ & $<0.0$ & $<0.020$ & $<0.020$ & $<0.020$ & $<0.020$ & $<0.020<$ & $<0.020$ & $<0.020$ \\
\hline & 1.266 & 0.988 & 1.107 & 0.889 & 2.019 & 0.541 & 1.268 & 1.092 & 1.122 & 1.089 & 1.228 & 1.002 & 2.604 & 1.909 & 1.745 & 0.938 & 1.361 & 1.097 \\
\hline lium & 0.864 & 0.870 & 0.870 & 0.763 & 1.729 & 0.772 & 1.295 & 1.037 & 1.171 & 1.273 & 1.355 & 1.161 & 0.776 & 0.697 & 0.916 & 0.603 & 0.732 & 0.770 \\
\hline & $<0.130$ & $<0.130$ & $<0.130$ & $<0.260<$ & $<0.260$ & $<0.260$ & $<0.260$ & $<0.260$ & $<0.260$ & $<0.260$ & $<0.260$ & $<0.260$ & $<0.260<$ & $<0.260$ & $<0.260$ & $<0.260<$ & $<0.260$ & $<0.260$ \\
\hline & 0.006 & 0.006 & 0.006 & 0.005 & 0.011 & 0.005 & 0.010 & 0.008 & 0.009 & 0.011 & 0.011 & 0.009 & 0.005 & 0.004 & 0.006 & 0.004 & 0.004 & 0.004 \\
\hline Illum & $<0.008$ & $<0.008$ & $<0.008$ & $<0.016<$ & $<0.016$ & $<0.016$ & $<0.016$ & $<0.016$ & $<0.016$ & $<0.016$ & $<0.016$ & $<0.016$ & $<0.016$ & $<0.016$ & $<0.016$ & $<0.016<$ & $<0.016$ & $<0.016$ \\
\hline & 0.092 & 0.069 & 0.093 & $<0.100$ & 0.102 & $<0.100$ & $<0.100$ & $<0.100$ & $<0.100$ & $<0.100$ & $<0.100$ & $<0.100$ & $<0.100$ & $<0.100$ & $<0.100$ & $<0.100<$ & $<0.100$ & $<0.100$ \\
\hline Vanadlum & $<0.010$ & $<0.010$ & $<0.010$ & $<0.020<$ & $<0.020$ & $<0.020$ & $<0.020$ & $<0.020$ & $<0.020$ & $<0.020$ & $<0.020$ & $<0.020$ & $<0.020$ & $<0.020$ & $<0.020$ & $<0.020<$ & $<0.020$ & $<0.020$ \\
\hline Zinc & $<0.005$ & $<0.005$ & 0.006 & $<0.010$ & 0.021 & $<0.010$ & $<0.010$ & $<0.010$ & $<0.010$ & $<0.010$ & $<0.010$ & $<0.010$ & 2.564 & 2.619 & 3.130 & 4.144 & 4.904 & 3.035 \\
\hline Zirco & $<0.010$ & 0.010 & $<0.010$ & $<0.020<$ & 0.020 & $<0.020$ & 0.033 & 0.032 & 0.030 & $<0.020$ & $<0.020$ & $<0.020$ & $<0.020$ & 0.023 & $<0.020$ & $<0.020<$ & $<0.020$ & $<0.020$ \\
\hline Mercury & 0.155 & 0.112 & 0.779 & 5503 & 4297 & 5893 & 7.38 & 10.42 & 8.05 & 15.3 & 14.2 & 15.9 & 30.5 & 12.0 & 115.0 & 41.10 & 3.260 & 55.0 \\
\hline
\end{tabular}

${ }^{a}$ Results in micrograms per liter. 
Table A.5. Leaching results (milligrams per liter) obtained at 1 month - pH 3

\begin{tabular}{|c|c|c|c|c|c|c|c|c|c|c|c|c|c|c|c|c|c|c|}
\hline & Blk-1 & Blk-2 & Blk-3 & HG-1 & HG-2 & HG-3. & LANL- & LANL- & LANL-1 & 2 Fern-1 & 9 Fern-20 & 0 Fern-21 & OR-11 & OR-12 & OR-16 & ID-24 & ID-24A & ID-28 \\
\hline Final pH & $\mathrm{nr}$ & $\mathrm{nr}$ & 2.88 & 2.52 & 2.58 & 2.65 & 3.42 & 3.28 & 3.29 & 3.96 & 4.18 & 4.26 & 5.28 & 5.43 & 4.89 & 5.87 & 5.60 & 6.60 \\
\hline Iver & $<0.003<$ & $=0.003<$ & $<0.003$ & 0.013 & 0.004 & 0.004 & $<0.013$ & $<0.013$ & $<0.013$ & $<0.005$ & $<0.005$ & $<0.005$ & $<0.013$ & $<0.013$ & $<0.013$ & $<0.005$ & $<0.005$ & $<0.005$ \\
\hline Aluminum & 0.048 & $=0.030$ & 0.039 & 0.422 & 0.357 & 0.321 & 4.941 & 4.242 & 4.563 & 0.271 & 0.180 & 0.210 & 0.670 & 0.524 & 0.368 & 0.102 & 0.159 & 0.061 \\
\hline Arsenic & $k 0.010<$ & $=0.010$ & $<0.010$ & $<0.010<$ & $<0.010<<$ & $<0.010$ & $<0.050$ & $<0.050$ & $<0.050$ & $<0.020$ & $<0.020$ & $<0.020$ & $<0.050$ & $<0.050$ & $<0.050$ & $<0.020$ & $<0.020$ & $<0.020$ \\
\hline Boron & $<0.020<$ & $=0.020$ & $<0.020$ & $<0.020<$ & $<0.020<$ & $<0.020$ & $\mid<0.100$ & $<0.100$ & $<0.100$ & $<0.040$ & $<0.040$ & $<0.040$ & 0.166 & 0.187 & 0.210 & 1.258 & 0.784 & 0.657 \\
\hline Barium & $<0.001$ & $=0.001<$ & $<0.001$ & $<0.001<$ & $<0.001<$ & $<0.001$ & 0.031 & 0.024 & 0.033 & 0.020 & 0.018 & 0.035 & $<0.005$ & $<0.005$ & $<0.005$ & 0.026 & 0.029 & 0.022 \\
\hline eryllium & 0.001 & 0.001 & 0.001 & 0.001 & 0.001 & 0.001 & 0.009 & 0.008 & 0.008 & 0.003 & 0.002 & 0.003 & 0.006 & 0.006 & 0.006 & 0.003 & 0.003 & 0.003 \\
\hline Calclum & 0.053 & $=0.040$ & $<0.040$ & $<0.040$ & 0.042 & $<0.040$ & 1085 & 872 & 1234 & 1907 & 2130 & 2639 & 4.034 & 2.887 & 2.858 & 19.024 & 11.675 & 18.767 \\
\hline Cadmium & $<0.001<$ & $\leqslant 0.001$ & $<0.001$ & $<0.001<$ & $<0.001$ & $<0.001$ & $<0.005$ & $<0.005$ & $<0.005$ & $<0.002$ & $<0.002$ & $<0.002$ & $<0.005$ & $<0.005$ & $<0.005$ & $<0.002$ & $<0.002$ & $<0.002$ \\
\hline Chromium & $<0.005<$ & & $<0.005$ & $<0.005<$ & $<0.005$ & $<0.005$ & 0.035 & 0.029 & 0.033 & 0.013 & 0.025 & 0.017 & 0.068 & $<0.025$ & $<0.025$ & $<0.010$ & $<0.010$ & $<0.010$ \\
\hline Copper & $<0.004$ & 0.004 & $<0.004$ & 3.141 & 2.626 & 2.349 & $<0.020$ & $<0.020$ & $<0.020$ & $<0.008$ & $<0.008$ & $<0.008$ & $<0.020$ & $<0.020$ & $<0.020$ & $<0.008$ & $<0.008$ & $<0.008$ \\
\hline Iron & $<0.050$ & $=0.050$ & $<0.050$ & $<<0.050<$ & $<0.050$ & $<0.050$ & 15.184 & 10.551 & 12.977 & 2.683 & 1.801 & 2.559 & $<0.250$ & $<0.250$ & $<0.250$ & 1.558 & 1.075 & 1.213 \\
\hline Potassium & 0.051 & 0.052 & 1.789 & 1.706 & 0.789 & 6.623 & 3.826 & 3.492 & 4.375 & 3.863 & 2.999 & 2.977 & 1.977 & 1.787 & 1.654 & 4.743 & 4.628 & 3.079 \\
\hline Magneslum & $\mid<0.020<$ & $=0.020$ & $<0.020$ & $<0.020<$ & $<0.020<$ & $<0.020$ & 2.911 & 2.040 & 2.629 & 10.241 & 7.131 & 11.396 & 419 & 407 & 417 & 1394 & 1096 & 1198 \\
\hline Mange & $<0.001$ & $=0.001$ & $<0.001$ & $<0.001<$ & $<0.001<<$ & $<0.001$ & 0.152 & 0.120 & 0.144 & 0.054 & 0.028 & 0.047 & 0.054 & 0.060 & 0.068 & 0.050 & 0.064 & 0.035 \\
\hline Sodium & 0.086 & 0.06 & $<0.060$ & 0.871 & 0.221 & 0.127 & 8.177 & 6.596 & 9.190 & 29.271 & 18.861 & 31.319 & 164.8 & 158.3 & 90.87 & 811 & 478 & 758 \\
\hline Nickel & $<0.004<$ & $=0.0$ & $<0.004$ & $<0.004<$ & $<0.004<<<$ & $<0.004$ & 0.021 & 0.023 & 0.024 & $<0.008$ & $<0.008$ & 0.008 & $<0.020$ & $<0.020$ & $<0.020$ & $<0.008$ & $<0.008$ & $<0.008$ \\
\hline Lead & $<0.007<$ & $=0.007$ & $<0.007$ & $<0.007<$ & $<0.007<<$ & $<0.007$ & $<0.035$ & $<0.035$ & $<0.035$ & $<0.014$ & $<0.014$ & $<0.014$ & $<0.035$ & $<0.035$ & $<0.035$ & $<0.014$ & $<0.014$ & $<0.014$ \\
\hline Selenlum & 0.016 & 0.016 & 0.013 & 0.018 & 0.017 & 0.019 & $<0.050$ & $<0.050$ & $<0.050$ & $<0.020$ & $<0.020$ & $<0.020$ & $<0.050$ & $<0.050$ & $<0.050$ & $<0.020$ & $<0.020$ & $<0.020$ \\
\hline Antimony & $<0.010$ & $<0.010$ & $<0.010$ & $<0.010<$ & $<0.010<$ & $<0.010$ & $<0.050$ & $<0.050$ & $<0.050$ & $<0.020$ & $<0.020$ & $<0.020$ & $<0.050$ & $<0.050$ & $<0.050$ & $<0.020$ & $<0.020$ & $<0.020$ \\
\hline Sillicon & & 0.558 & 0.586 & 0.622 & 0.605 & 0.560 & 20.244 & 13.846 & $5 \quad 17.400$ & 6.349 & 4.525 & 7.090 & 1.207 & 1.001 & 1.045 & 2.383 & 1.463 & 1.416 \\
\hline Strontium & $<0.001<$ & $<0.001<$ & $<0.001$ & $<0.001<$ & $<0.001<$ & $<0.001$ & 0.352 & 0.266 & 0.419 & 0.813 & 0.713 & 1.096 & 0.009 & 0.008 & 0.008 & 0.079 & 0.047 & 0.076 \\
\hline & $<0.1$ & $<0.1$ & $<0.130$ & $<0.130<$ & $<0.130<<$ & $<0.130$ & $<0.650$ & $<0.650$ & $<0.650$ & $<0.260$ & $<0.260$ & $<0.260$ & $<0.650$ & $<0.650$ & $<0.650$ & $<0.260$ & $<0.260$ & $<0.260$ \\
\hline nium & $<0.0$ & $<0.001$ & $<0.001$ & $<0.001<$ & $<0.001$ & $<0.001$ & 0.007 & 0.007 & 0.008 & 0.011 & 0.013 & 0.014 & $<0.005$ & $<0.005$ & $<0.005$ & 0.002 & 0.003 & $<0.002$ \\
\hline Thallium & $<0.008$ & $<0.008$ & $<0.008$ & $<0.008<$ & $<0.008$ & $<0.008$ & $<0.040$ & $<0.040$ & $<0.040$ & $<0.016$ & $<0.016$ & $<0.016$ & $<0.040$ & $<0.040$ & $<0.040$ & $<0.016$ & $<0.016$ & $<0.016$ \\
\hline & & 0.060 & $<0.050$ & 0.085 & 0.081 & 0.059 & $<0.250$ & $<0.250$ & $<0.250$ & $<0.100$ & 0.139 & $<0.100$ & $<0.250$ & $<0.250$ & $<0.250$ & $<0.100$ & $<0.100$ & $<0.100$ \\
\hline & $<0.010$ & $<0.010$ & $<0.010$ & $<0.010<$ & $<0.010<$ & $<0.010$ & $<0.050$ & $<0.050$ & $<0.050$ & 0.031 & $<0.020$ & 0.031 & $<0.050$ & $<0.050$ & $<0.050$ & $<0.020$ & $<0.020$ & $<0.020$ \\
\hline$Z \ln$ & 0.011 & 0.008 & 0.008 & 0.011 & 0.012 & 0.011 & 0.142 & 0.153 & 0.105 & $<0.010$ & 0.015 & 0.010 & 280.1 & 274.6 & 271.9 & 102.1 & 108.7 & 94.16 \\
\hline Zirconlum & $<0.010$ & $<0.010$ & $<0.010$ & $<0.010<$ & $<0.010$ & $<0.010$ & $<0.050$ & $<0.050$ & $<0.050$ & 0.048 & 0.024 & 0.053 & 0.251 & 0.276 & 0.213 & 0.112 & 0.118 & 0.107 \\
\hline Mercury & $<0.050$ & $<0.050$ & 0.109 & 1397 & 1303 & 1311 & 30.0 & 48.1 & 45.7 & 5.02 & 3.70 & 4.70 & 60.4 & 115.1 & 53.8 & 412 & 82.7 & 81.3 \\
\hline
\end{tabular}

${ }^{2}$ Resuits in micrograms per liter. 
Table A.6. Leaching results (milligrams per liter) obtained at 1 month - pH 5

\begin{tabular}{|c|c|c|c|c|c|c|c|c|c|c|c|c|c|c|c|c|c|c|}
\hline & ik- & Blk- & & HG-10 & HG-11 & HG-12 & Lanl-4 & Lanl-5 & Lanl-7 & Fern-13 & 3 Fern-14 & 4 Fern- & OR- & OR- & OR- & ID- & ID- & 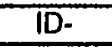 \\
\hline bifat & & - & - & 10 & 16 & 7 & 12.22 & 9.80 & 11.08 & 26.92 & 36.77 & 19.6 & & & 8.51 & 7.85 & 3.80 & 5.29 \\
\hline & & $\mathrm{nr}$ & $\mathrm{nr}$ & .00 & & & 63 & 4.63 & 4.63 & 63 & & 4.63 & & & 4.63 & & & \\
\hline & & $\mathrm{nr}$ & nr & 69 & & 4.77 & & & & & & & & & & .78 & & 5.74 \\
\hline V & & & & -0.000 & & & $<0.013$ & $<0.013$ & $<0.013$ & 05 & & $<0.005$ & $<0.013$ & $<0.013$ & $<0.013$ & $<0.005$ & 3.005 & $<0.005$ \\
\hline & & & & 0.223 & 0.252 & 0.199 & 0.639 & 0.539 & 0.764 & & & & & & 0.248 & & & $<0.060$ \\
\hline & 01 & & 10 & $<0.010<$ & & $<0.010$ & $<0.050$ & $<0.050$ & .050 & & 0.031 & $<0.020$ & 0.050 & & 0.050 & $<0.0$ & & 0.020 \\
\hline & & & & $0.0<0$ & & $<0.020$ & $<0.100$ & $<0.100$ & .100 & & & $<0.040$ & 0.100 & & .100 & 0.087 & 40 & $<0.040$ \\
\hline & 00 & & & 0.001 & 001 & $<0.001$ & 0.033 & 0.024 & 029 & & & 0.038 & 05 & $<0.005$ & $<0.005$ & 0.024 & 0.021 & 0.017 \\
\hline & 0 & & & 0.001 & 0.001 & 0.001 & .009 & 0.009 & 0.009 & & & 0.004 & 0.007 & 0.007 & 0.007 & .003 & 0.0 & 0.003 \\
\hline & 04 & & & 0.688 & 0.147 & & & 842 & & 3061 & & 2431 & 4.433 & 5.722 & 5.961 & 18.96 & 9.77 & 14.79 \\
\hline & & & $<0$ & $<0.001<$ & $<0.001$ & $<0.001$ & $<0.005$ & $<0.005$ & $<0.005$ & $<0.002$ & $<0.002$ & $<0.002$ & $<0.005$ & $<0.005$ & $<0.005$ & $<0.002$ & $<0.002$ & $<0.002$ \\
\hline & & & & & & & 025 & & & & & $<0.010$ & $<0.025$ & $<0.025$ & $<0.025$ & $<0.0$ & 0.010 & $<0.010$ \\
\hline & $n g$ & & & 2.954 & 4.382 & 2.646 & 0.020 & $<0.020$ & .020 & & 0.011 & $<0.008$ & $<0.020$ & .020 & $<0.020$ & $<0.008$ & $<0.008$ & $<0.008$ \\
\hline & & & & $<0.050$ & $<0.050$ & $<0.050$ & 7.680 & 7.202 & 8.123 & 1.313 & $<0$. & 1.527 & $<0.250$ & 250 & $<0.250$ & 0.451 & 0.222 & $<0.100$ \\
\hline & 1 & 0.3 & 1.490 & 1.167 & 2.346 & 1.045 & 4.716 & 4.209 & 4.212 & 5.121 & & 4.270 & 68 & 367 & 2.973 & 4.279 & & 2.735 \\
\hline & 0 & & $<0.020$ & $<0.020<$ & $<0.020$ & $<0.020$ & 2.462 & 1.805 & 1.968 & 13.379 & 71 & 9.981 & 45 & 5 & 501 & 727 & 534 & 345 \\
\hline & 0.08 & $<0.0$ & $<0.001$ & $<0.001$ & $<0.001$ & $<0.001$ & 0.192 & 0.107 & & & & 0.019 & & & & 02 & & 0.006 \\
\hline & & & & & 1209 & 1206 & 1525 & 1516 & 1505 & 13 & & 1373 & 1549 & 1625 & 1594 & 2035 & 1680 & 1820 \\
\hline & $=000$ & $<0.0$ & $<0.004$ & $<0.004$ & $<0.004$ & $<0.004$ & $<0.020$ & $<0.020$ & .020 & 0.008 & $<0.008$ & $<0.008$ & 0.020 & 0.020 & 20 & 0.0 & 08 & .008 \\
\hline & & & & $<0.007<$ & $<0.007$ & .007 & .035 & & & & & .014 & & & 0.035 & 000 & & $<0.014$ \\
\hline & & & $<$ & $<0.010<$ & $<0.010$ & $<0.010$ & 050 & 050 & & & & $<0.020$ & 50 & & $<0.050$ & $<0.020$ & $<0.020$ & $<0.020$ \\
\hline & & & $<0.010$ & 0010 & $<0.010$ & & 0.050 & $<0.050$ & & 20 & 20 & $<0.020$ & 50 & & $<0.050$ & $<0.020$ & $<0.020$ & $<0.020$ \\
\hline & 0.5 & 0.5 & 0.554 & 0.608 & 0.558 & 0.554 & 19.302 & $2 \quad 14.075$ & 17.133 & 606 & 806 & 8.045 & 0.824 & & 0.773 & 1.0 & 1.093 & 1.318 \\
\hline & & $<0$ & $<0$. & $<0.001$ & $<0.001$ & & 0.335 & 0.232 & 0.293 & & & 1.048 & 011 & & 0.015 & 0.081 & 0.040 & 0.059 \\
\hline & & & & $<0.130$ & $<0.130$ & $<0.130$ & $<0.650$ & $<0.650$ & $<0.650$ & $<0.260$ & $<0.260$ & $<0.260$ & $<0.650$ & $<0.650$ & $<0.650$ & $<0.260$ & $<0.260$ & $<0.260$ \\
\hline & & & & $<0.001$ & & $<0.001$ & 0.006 & $<0.005$ & 0.006 & 0.016 & 0.023 & 0.014 & $<0.005$ & $<0.005$ & $<0.005$ & $<0.002$ & 0.002 & $<0.002$ \\
\hline & & & & $<0.008<$ & $<0.008$ & $<0.008$ & $<0.040$ & $<0.040$ & $<0.040$ & $<0.016$ & $<0.016$ & $<0.016$ & & & $<0.040$ & $<0.016$ & $<0.016$ & $<0.016$ \\
\hline & 0.050 & 0.057 & 0.079 & & & & & & & & & 0.140 & $<0.250$ & $<0.250$ & $<0.250$ & $<0.100$ & $<0.100$ & $<0.100$ \\
\hline & & $<0.0$ & $<0.010$ & $<0.010$ & $<0.010$ & $<0.010$ & $<0.050$ & $<0.050$ & $<0.050$ & $<0.020$ & $<0.020$ & $<0.020$ & $<0.050$ & $<0.050$ & $<0.050$ & $<0.020$ & $<0.020$ & $<0.020$ \\
\hline & & & & & & & & & & & $<0.010$ & $<0.010$ & & & 8.0 & 61.20 & & 62.67 \\
\hline & & $<0.0$ & $<0.010$ & $<0.010$ & 0.014 & $<0.010$ & 0.055 & $<0.050$ & $<0.050$ & 0.043 & 0.046 & 0.032 & .167 & & & .086 & & 0.070 \\
\hline telcuiy & 0.838 & $<0.050$ & 0.489 & 3393 & 4584 & 3980 & 47.5 & 60.0 & 54.5 & 32.2 & 10.30 & 42.4 & 97.5 & 102.9 & 125.1 & 124. & 138.8 & 135.3 \\
\hline
\end{tabular}

${ }^{a}$ Results in micrograms per liter. 
Table A.7. Leaching results (milligrams per liter) obtained at 1 month - pH 7

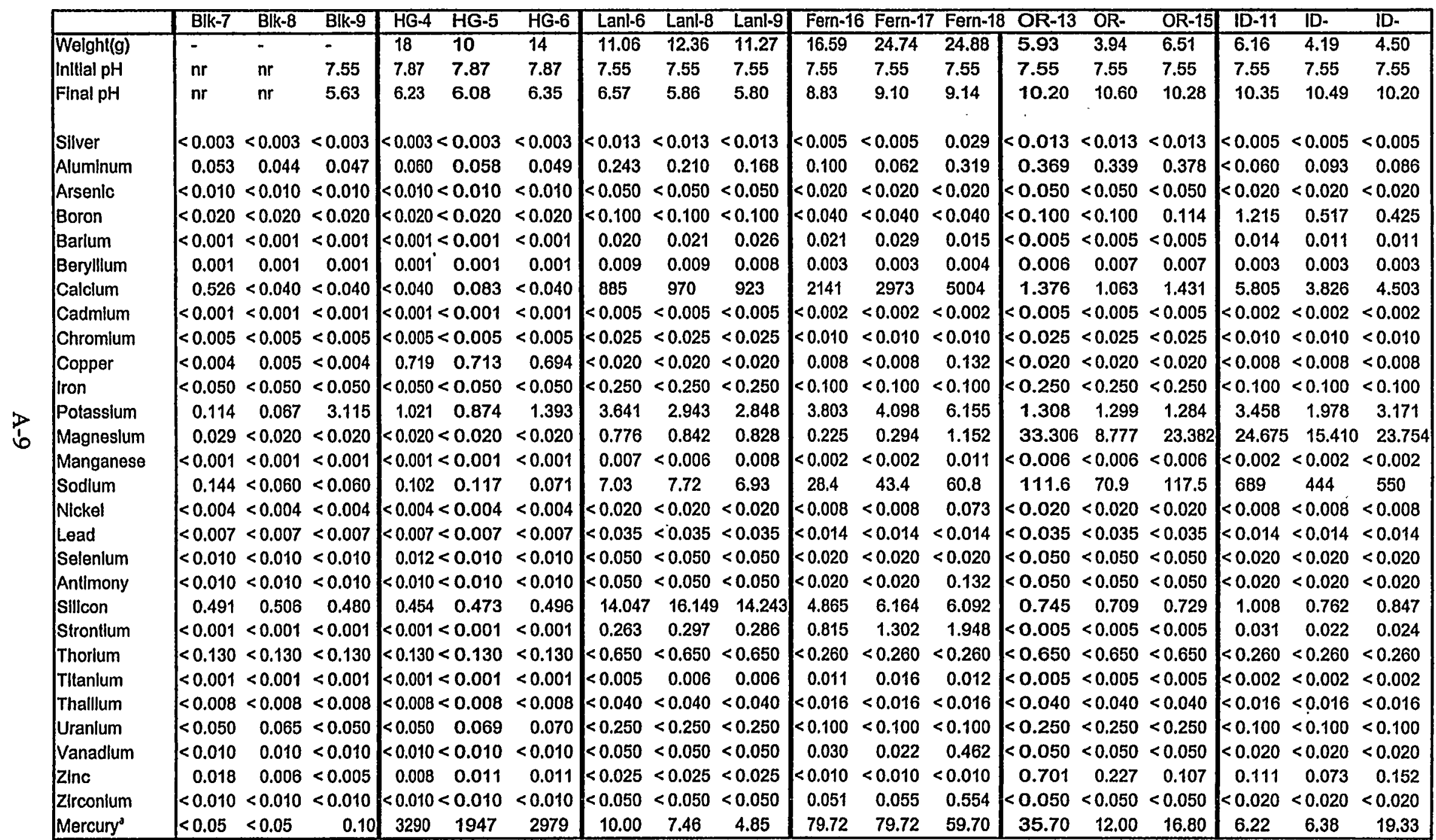

${ }^{a}$ Results in micrograms per liter. 
Table A.8. Leaching results (milligrams per liter) obtained at 1 month - pH 12.5

\begin{tabular}{|c|c|c|c|c|c|c|c|c|c|c|c|c|c|c|c|c|c|c|}
\hline & Blk-4 & BIk-5 & Blk-6 & HG-7 & HG-8 & HG-g & Lanl-1 & Lanl-2 & Lanl-3 & Fern-1 & 10 Fern-1 & 11 Fern-12 & OR- & OR-2 & OR- & ID-13 & $10-14$ & ID-14A \\
\hline Welght(g) & . & 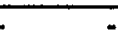 & 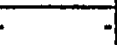 & 7 & 9 & 9 & 7.51 & 9.79 & 9.96 & 14.74 & 18.54 & 19.30 & 5.62 & 6.44 & 7.85 & 5.34 & 5.50 & 4.80 \\
\hline Initial pH & $\mathrm{nr}$ & $\mathrm{nr}$ & 12.53 & 12.53 & 12.53 & 12.53 & 12.68 & 12.68 & 12.68 & 12.68 & 12.68 & 12.68 & 12.53 & 12.53 & 12.53 & 12.53 & 12.53 & 12.5 \\
\hline Final pH & $\mathrm{nr}$ & $\mathrm{nr}$ & 12.72 & 12.06 & 12.39 & 12.35 & 12.55 & 12.17 & 11.89 & 12.40 & 12.43 & 12.34 & 12.27 & 12.19 & 12.20 & 12.15 & 12.22 & 12.2 \\
\hline Sllver & $<0.003$ & $<0.003$ & $<0.003$ & $<0.003$ & $<0.003$ & $<0.003$ & 0.015 & $<0.013$ & $<0.013$ & 0.029 & $<0.005$ & $<0.005$ & $<0.013$ & $<0.013$ & $<0.013$ & $<0.005$ & $<0.005$ & $<0.005$ \\
\hline Alum & 0.047 & 0.053 & 0.049 & 0.057 & 0.060 & 0.059 & $<0.150$ & 0.285 & 0.272 & 0.212 & 0.154 & 0.118 & 0.383 & 0.341 & 0.374 & $<0.060$ & 0.069 & $<0.060$ \\
\hline Arsenlc & $<0.010$ & $<0.010$ & $<0.010$ & 0.011 & $<0.010$ & $<0.010$ & $<0.050$ & $<0.050$ & $<0.050$ & $<0.020$ & 0.021 & 0.022 & $<0.050$ & $<0.050$ & $<0.050$ & $<0.020$ & $<0.020$ & $<0.020$ \\
\hline Boron & $<0.020$ & $<0.020$ & $<0.020$ & $<0.020$ & $<0.020$ & $<0.020$ & $<0.100$ & $<0.100$ & $<0.100$ & $<0.040$ & $<0.040$ & $<0.040$ & 0.178 & 0.201 & 0.235 & 1.402 & 1.239 & 1.337 \\
\hline Barium & 0.012 & 0.012 & 0.012 & 0.013 & 0.014 & 0.015 & 0.053 & 0.069 & 0.064 & 0.024 & 0.042 & 0.042 & 0.011 & 0.010 & 0.010 & 0.033 & 0.037 & 0.033 \\
\hline Beryllium & 0.001 & 0.001 & 0.001 & 0.001 & 0.001 & 0.001 & 0.007 & 0.009 & 0.009 & 0.003 & 0.004 & 0.003 & 0.007 & 0.007 & 0.007 & 0.003 & 0.003 & 0.003 \\
\hline Calci & 1192 & 1175 & 1179 & 1223 & 1237 & 1244 & 1886 & 1588 & 1437 & 6343 & 4248 & 4621 & 525 & 588 & 591 & 643 & 498 & 479 \\
\hline Cadmium & $<0.001$ & $<0.001$ & $<0.001$ & $<0.001$ & $<0.001$ & $<0.001$ & $<0.005$ & $<0.005$ & $<0.005$ & $<0.002$ & $<0.002$ & $<0.002$ & $<0.005$ & $<0.005$ & $<0.005$ & $<0.002$ & $<0.002$ & $<0.002$ \\
\hline Chromlum & 0.012 & 0.013 & 0.014 & 0.014 & 0.015 & 0.018 & $<0.025$ & $<0.025$ & $<0.025$ & $<0.010$ & $<0.010$ & $<0.010$ & $<0.025$ & $<0.025$ & $<0.025$ & $<0.010$ & .010 & $<0.010$ \\
\hline Copper & 0.013 & 0.010 & 0.011 & 0.405 & 0.415 & 0.320 & $<0.020$ & 0.076 & 0.023 & 0.128 & 0.021 & 0.023 & $<0.020$ & $<0.020$ & $<0.020$ & $<0.008$ & $<0.008$ & $<0.008$ \\
\hline Iron & $<0.050$ & $<0.050$ & $<0.050$ & $<0.050$ & $<0.050$ & $<0.050$ & $<0.250$ & $<0.250$ & $<0.250$ & $<0.100$ & $<0.100$ & $<0.100$ & $<0.250$ & $<0.250$ & $<0.250$ & $<0.100$ & $<0.100$ & $<0.100$ \\
\hline Potassium & 0.139 & 0.160 & 1.314 & 1.087 & 1.096 & 1.221 & 3.001 & 4.368 & 4.379 & 6.419 & 3.635 & 3.560 & 2.362 & 2.607 & 1.994 & 4.220 & 5.913 & 3.101 \\
\hline Magneslum & $<0.020$ & 0.026 & $<0.020$ & $<0.020$ & $<0.020$ & $<0.020$ & $<0.100$ & $<0.100$ & $<0.100$ & 0.736 & 0.115 & 0.114 & 0.122 & $<0.100$ & $<0.100$ & 0.169 & 0.111 & $<0.040$ \\
\hline Manganese & $<0.001$ & $<0.001$ & $<0.001$ & $<0.001$ & $<0.001$ & $<0.001$ & 0.008 & $<0.006$ & $<0.006$ & 0.009 & $<0.002$ & $<0.002$ & $<0.006$ & $<0.006$ & $<0.006$ & $<0.002$ & $<0.002$ & $<0.002$ \\
\hline Sodit & 0.550 & 0.553 & 0.555 & 0.611 & 0.612 & 0.649 & 5.727 & 7.622 & 7.884 & 37.38 & 32.152 & 35.783 & 106.6 & 114.2 & 147.2 & 512 & 523 & 438 \\
\hline Nicke & & & $<0.004$ & $<0.004$ & & $<0.004$ & $<0.020$ & & $<0.02$ & 0.057 & $<0.008$ & $<0.008$ & 0.020 & $<0.020$ & .020 & $<0.008$ & 0.008 & .008 \\
\hline Lead & $<0.007$ & 007 & $<0.007$ & $<0.007$ & $<0.007$ & $<0.007$ & $<0.035$ & $<0.035$ & $<0.035$ & $<0.014$. & $<0.014$ & $<0.014$ & $<0.035$ & $<0.035$ & $<0.035$ & $<0.014$ & $<0.014$ & $<0.014$ \\
\hline $\mathrm{um}$ & & & $<0.010$ & $<0.010$ & & 010 & 050 & & $<0.050$ & $<0.020$ & 20 & $<0$ & 0.050 & $<0.050$ & $<0$ & $<0.020$ & .020 & $<0.020$ \\
\hline ony & $<0.010$ & $<0.010$ & $<0.010$ & $<0.010$ & $<0.010$ & $<0.010$ & $<0.050$ & $<0.050$ & $<0.050$ & 0.101 & $<0.020$ & $<0.020$ & $<0.050$ & $<0.050$ & $<0.050$ & $<0.020$ & $<0.020$ & $<0.020$ \\
\hline & & & 0.904 & 0.897 & & 0.902 & 1.763 & 1.170 & 1.429 & 2.692 & & 2.151 & 1.118 & 1.142 & 1.383 & 1.052 & 0.965 & 1.319 \\
\hline um & 0.719 & 0.718 & 0.744 & 0.776 & 0.825 & 0.855 & 1.234 & 1.178 & 1.138 & 3.030 & 2.462 & 2.570 & 0.469 & 0.441 & 0.449 & 0.588 & 0.574 & 0.552 \\
\hline $\mathrm{um}$ & $<0.130$ & $<0.130$ & $<0.130$ & $<0.130$ & $<0.130$ & $<0.130$ & $<0.650$ & $<0.650$ & $<0.650$ & $<0.260$ & $<0.260<$ & $<0.260$ & $<0.650$ & $<0.650$ & $<0.650$ & $<0.260$ & $<0.260$ & $<0.260$ \\
\hline & 0.005 & 0.005 & 0.005 & 0.005 & 0.005 & 0.005 & 0.013 & 0.009 & 0.008 & 0.026 & 0.021 & 0.024 & $<0.005$ & $<0.005$ & 0.005 & 0.004 & 0.003 & 0.003 \\
\hline um & $<0.008$ & $<0.008$ & $<0.008$ & $<0.008$ & $<0.008$ & $<0.008$ & $<0.040$ & $<0.040$ & $<0.040$ & $<0.016$ & $<0.016$ & $<0.016$ & $<0.040$ & $<0.040$ & $<0.040$ & $<0.016$ & $<0.016$ & $<0.016$ \\
\hline & 0.073 & 0.057 & $<0.050$ & 0.067 & 0.069 & 0.071 & $<0.250$ & $<0.250$ & $<0.250$ & $<0.100$ & $<0.100$ & $<0.100$ & $<0.250$ & $<0.250$ & $<0.250$ & $<0.100$ & $<0.100$ & $<0.100$ \\
\hline Vanadlum & 0.010 & $<0.010$ & $<0.010$ & $<0.010$ & $<0.010$ & $<0.010$ & $<0.050$ & $<0.050$ & $<0.050$ & 0.354 & 0.028 & 0.035 & $<0.050$ & $<0.050$ & $<0.050$ & 0.024 & $<0.020$ & $<0.020$ \\
\hline Zinc & 0.007 & 0.007 & 0.009 & 0.006 & 0.006 & 0.008 & $<0.025$ & $<0.025$ & $<0.025$ & $<0.010$ & $<0.010$ & $<0.010$ & 1.782 & 1.756 & 1.574 & 1.302 & 1.121 & 1.605 \\
\hline Zirconlum & $<0.010$ & $<0.010$ & 0.011 & $<0.010$ & $<0.010$ & $<0.010$ & $<0.050$ & $<0.050$ & $<0.050$ & 0.353 & 0.054 & 0.055 & $<0.050$ & $<0.050$ & $<0.050$ & 0.033 & 0.032 & $<0.020$ \\
\hline Mercury" & $<0.05$ & $<0.05$ & 0.32 & 6398 & 6989 & 6396 & 4.6 & 4.8 & 8.2 & 25 & 43.7 & 57.5 & 47.0 & 102.3 & 94.3 & 65.5 & 131.2 & 13.9 \\
\hline
\end{tabular}

${ }^{a}$ Results in micrograms per liter. 
Table A.9. Leaching results (milligrams per liter) obtained at 2 months - pH 3

\begin{tabular}{|c|c|c|c|c|c|c|c|c|c|c|c|c|c|c|c|c|c|c|}
\hline & B|k-M & Blk-N & Blk-O & HG-14 & HG-17 & HG-18 & LANL- & LANL- & LANL- & Fern-37 & 7 Fern-3 & 8 Fern-39 & 9 OR-28 & OR-29 & OR-30 & ID- & ID- & ID. \\
\hline$\overline{\text { Welght(g) }}$ & & & & 4.91 & 5.92 & 5.04 & 14.44 & 12.94 & 14.00 & 14.37 & 13.26 & 17.41 & 8.28 & 9.26 & 16.63 & 5.44 & 6.38 & 4.32 \\
\hline Inllial pH & 2.85 & 3.05 & 3.05 & 3.05 & 2.85 & 2.85 & 3.05 & 3.05 & 3.05 & 3.05 & 3.05 & 3.05 & 3.05 & 3.05 & 3.05 & 3.05 & 2.85 & 2.85 \\
\hline Final pH & 2.81 & 2.87 & 2.88 & 2.94 & 2.89 & 2.81 & 3.79 & 3.76 & 3.74 & 4.50 & 4.56 & 4.89 & 5.72 & 5.80 & 7.42 & 5.56 & 6.05 & 5.44 \\
\hline Silver & $<0.003$ & $<0.003$ & $<0.003$ & $<0.013$ & $<0.013$ & $<0.013$ & $<0.013$ & $<0.013$ & $<0.013$ & $<0.013$ & $<0.013$ & $<0.013$ & $<0.013$ & $<0.013$ & $<0.013$ & $<0.013$ & $<0.013<$ & $<0.013$ \\
\hline Aluminum & 0.040 & 0.073 & 0.068 & 0.506 & 0.484 & 0.423 & 7.709 & 6,011 & 7.035 & 0.211 & $<0.150$ & 0.238 & 0.309 & 0.273 & 0.229 & 0.212 & $<0.150$ & 0.236 \\
\hline Arsenic & $<0.010$ & $<0.010$ & $<0.010$ & $<0.050$ & $<0.050$ & $<0.050$ & $<0.050$ & $<0.050$ & $<0.050$ & $<0.050$ & $<0.050$ & $<0.050$ & $<0.050$ & $<0.050$ & $<0.050$ & $<0.050$ & $<0.050<$ & $<0.050$ \\
\hline Boron & $<0.020$ & $<0.020$ & $<0.020$ & $<0.100$ & $<0.100$ & $<0.100$ & $<0.100$ & $<0.100$ & $<0.100$ & $<0.100$ & $<0.100$ & $<0.100$ & 0.348 & 0.282 & 0.248 & 0.585 & 0.747 & 0.733 \\
\hline Barium & $<0.001$ & $<0.001$ & $<0.001$ & $<0.005$ & $<0.005$ & $<0.005$ & 0.041 & 0.037 & 0.039 & 0.024 & 0.022 & 0.036 & $<0.005$ & $<0.005$ & $<0.005$ & 0.023 & 0.028 & 0.028 \\
\hline Beryllium & 0.001 & 0.002 & 0.002 & 0.012 & 0.012 & 0.011 & 0.014 & 0.014 & 0.014 & $<0.003$ & $<0.003$ & 0.003 & 0.007 & 0.007 & 0.007 & 0.004 & 0.004 & 0.005 \\
\hline Calclum & $<0.040$ & 0.170 & $<0.040$ & 0.397 & $<0.200$ & $<0.200$ & 1330 & 1160 & 1258 & 2036 & 1896 & 2251 & 3.95 & 5.11 & 7.84 & 15.80 & 15.67 & 13.12 \\
\hline Cadmlum & $<0.001$ & $<0.001$ & $<0.001$ & $<0.005$ & $<0.005$ & $<0.005$ & $<0.005$ & $<0.005$ & $<0,005$ & $<0.005$ & $<0.005$ & $<0.005$ & $<0.005$ & $<0.005$ & $<0.005$ & $<0.005$ & $<0.005<$ & $<0.005$ \\
\hline Chromium & $<0.005$ & $<0.005$ & $<0.005$ & $<0.025$ & $<0.025$ & $<0.025$ & 0.035 & 0.025 & 0.026 & $<0.025$ & $<0.025$ & $<0.025$ & $<0.025$ & $<0.025$ & $<0.025$ & $<0.025$ & $<0.025<$ & $<0.025$ \\
\hline Copper & $<0.004$ & $<0.004$ & $<0.004$ & 1.075 & 1.276 & 1.108 & $<0.020$ & $<0.020$ & $<0.020$ & 0.028 & $<0.020$ & 0.027 & $<0.020$ & $<0.020$ & $<0.020$ & $<0.020$ & $<0.020<$ & $<0.020$ \\
\hline Iron & $<0.050$ & $<0.050$ & $<0.050$ & $<0.250$ & $<0.250$ & $<0.250$ & 19.95 & 16.06 & 23.40 & 1.607 & 1.369 & 1.885 & $<0.250$ & $<0.250$ & $<0.250$ & $<0.250$ & 0.549 & 0.299 \\
\hline Potassium & 5.617 & 5.072 & 4.81 & 4.831 & 4.676 & 4.268 & 9.32 & 8.888 & 11.19 & 6.717 & 7.219 & 6.88 & 5.669 & 5.642 & 9.714 & 8.137 & 6.868 & 10.248 \\
\hline Magnesium & $<0.020$ & $<0.020$ & $<0.020$ & $<0.100$ & $<0.100$ & $<0.100$ & 3.499 & 2.988 & 3.181 & 8.741 & 8.280 & 10.87 & 700 & 751 & 1000 & 925 & 1255 & 1070 \\
\hline Manganese & $<0.001$ & $<0.001$ & $<0.001$ & $<0.006$ & $<0.006$ & $<0.006$ & 0.212 & 0.198 & 0.477 & 0.030 & 0.026 & 0.031 & 0.186 & 0.175 & 0.159 & 0.148 & 0.149 & 0.160 \\
\hline Sodium & 0.070 & 0.073 & $<0.060$ & 0.303 & $<0.300$ & $<0.300$ & 10.99 & 9.167 & 10.48 & 23.55 & 23.25 & 29.94 & 155 & 183 & 331 & 644 & 746 & 514 \\
\hline Nlckel & $<0.004$ & $<0.004$ & $<0.004$ & $<0.020$ & $<0.020$ & $<0.020$ & 0.028 & 0.026 & 0.028 & $<0.020$ & $<0.020$ & $<0.020$ & $<0.020$ & $<0.020$ & $<0.020$ & $<0.020$ & $<0.020<$ & $<0.020$ \\
\hline Lead & $<0.007$ & $<0.007$ & $<0.007$ & $<0.035$ & $<0.035$ & $<0.035$ & $<0.035$ & $<0.035$ & $<0.035$ & $<0.035$ & $<0.035$ & $<0.035$ & $<0.035$ & $<0.035$ & $<0.035$ & $<0.035$ & $<0.035<$ & $<0.035$ \\
\hline Selenlum & 0.023 & 0.029 & 0.028 & 0.101 & 0.093 & 0.082 & 0.071 & 0.078 & 0.086 & $<0.050$ & $<0.050$ & $<0.050$ & $<0.050$ & $<0.050$ & $<0.050$ & $<0.050$ & $<0.050<$ & $<0.050$ \\
\hline Antimony & $<0.010$ & $<0.010$ & $<0.010$ & $<0.050$ & $<0.050$ & $<0.050$ & $<0.050$ & $<0.050$ & $<0.050$ & $<0.050$ & $<0.050$ & $<0.050$ & $<0.050$ & $<0.050$ & $<0.050$ & $<0.050$ & $<0.050<$ & $<0.050$ \\
\hline Sillicon & 0.539 & 0.537 & 0.563 & 0.461 & 0.449 & 0.468 & 31.23 & 27.07 & 28.81 & 6.737 & 6.114 & 8.195 & 0.887 & 0.799 & 0.391 & 1.264 & 0.568 & 1.171 \\
\hline Strontlum & $<0.001$ & $<0.001$ & $<0.001$ & $<0.005$ & $<0.005$ & $<0.005$ & 0.423 & 0.351 & 0.400 & 0.579 & 0.544 & 0.722 & 0.012 & 0.015 & 0.022 & 0.064 & 0.063 & 0.055 \\
\hline Thorium & $<0.130$ & $<0.130$ & $<0.130$ & $<0.650$ & $<0.650$ & $<0.650$ & $<0.650$ & $<0.650$ & $<0.650$ & $<0.650$ & $<0.650$ & $<0.650$ & $<0.650$ & $<0.650$ & $<0.650$ & $<0.650$ & $<0.650<$ & $<0.650$ \\
\hline Tilanium & $<0.001$ & 0.001 & $<0.001$ & $<0.005$ & $<0.005$ & $<0.005$ & 0.007 & 0.007 & 0.007 & 0.014 & 0.013 & 0.015 & $<0.005$ & $<0.005$ & $<0.005$ & $<0.005$ & $<0.005<$ & $<0.005$ \\
\hline Thalllum & $<0.008$ & $<0.008$ & $<0.008$ & $<0.040$ & $<0.040$ & $<0.040$ & $<0.040$ & $<0.040$ & $<0.040$ & $<0.040$ & $<0.040$ & $<0.040$ & $<0.040$ & $<0.040$ & $<0.040$ & $<0.040$ & $<0.040<$ & $<0.040$ \\
\hline Uranlum & $<0.050$ & 0.054 & $<0.050$ & $<0.250$ & $<0.250$ & $<0.250$ & $<0.250$ & $<0.250$ & $<0.250$ & 0.322 & 0.326 & 0.361 & $<0.250$ & $<0.250$ & $<0.250$ & $<0.250$ & $<0.250<$ & $<0.250$ \\
\hline Vanadlum & $<0.010$ & $<0.010$ & $<0.010$ & $<0.050$ & $<0.050$ & $<0.050$ & $<0.050$ & $<0.050$ & $<0.050$ & $<0.050$ & $<0.050$ & $<0.050$ & $<0.050$ & $<0.050$ & $<0.050$ & $<0.050$ & $<0.050<$ & $<0.050$ \\
\hline Zinc & 0.008 & 0.005 & 0.007 & $<0.025$ & $<0.025$ & $<0.025$ & 0.116 & 0.280 & 0.112 & 0.070 & 0.187 & 0.523 & 245.9 & 241.3 & 113.7 & 179.0 & 224.3 & 233.6 \\
\hline Zirconlum & $<0.010$ & $<0.010$ & $<0.010$ & $<0.050$ & $<0.050$ & $<0.050$ & $<0.050$ & $<0.050$ & $<0.050$ & $<0.050$ & $<0.050$ & $<0.050$ & 0.229 & 0.209 & 0.121 & .0 .149 & 0.198 & 0.219 \\
\hline Mercury & $<0.050$ & $<0.050$ & $<0.050$ & 113 & 729 & 769 & $<0.050$ & $<0.050$ & $<0.050$ & 1.800 & 6.300 & 7.000 & 2.100 & 9.800 & 1.500 & 818.0 & 49.5 & 11.0 \\
\hline
\end{tabular}

${ }^{a}$ Results in micrograms per liter. 
Table A.10. Leaching results (milligrams per liter) obtained at 2 months - pH 5

\begin{tabular}{|c|c|c|c|c|c|c|c|c|c|c|c|c|c|c|c|c|c|c|}
\hline & Blk-S & B!k-T & Blk-U & HG-M & HG-N & HG-O & Lanl-19 & Lanl-20 & Lanl-21 & Fern-28 & Fern-29 & Fern-3 & 30 OR- & OR-38 & OR-39 & ID-17 & $1 D-18$ & ID-19A \\
\hline Welght(g) & & & & 14.00 & 11.00 & 8.00 & 13.15 & 11.17 & 13.84 & 19.75 & 20.58 & 17.67 & 9.12 & 7.15 & 9.15 & 6.37 & 6.26 & 6.02 \\
\hline Inilial pH & 4.63 & 4.89 & 4.89 & 4.63 & 4.63 & 4.63 & 4.89 & 4.89 & 4.89 & 4.89 & 4.89 & 4.89 & 4.89 & 4.89 & 4.89 & 4.89 & 4.63 & 4.63 \\
\hline FInal pH & 4.78 & 4.97 & 5.00 & 4.75 & 4.77 & 4.77 & 5.00 & 5.07 & 5.12 & 7.28 & 8.58 & 6.43 & 6.86 & 6.03 & 7.50 & 10.06 & 6.68 & 5.95 \\
\hline Silver & $<0.003<$ & $0.003<$ & 0.003 & $<0.013<$ & $0.013<$ & 0.013 & $<0.013<$ & $0.013<$ & 0.013 & $<0.013$ & $<0.013<$ & 0.013 & $3<0.013<$ & 0.013 & $<0.013$ & $<0.013$ & $<0.013<$ & 0.013 \\
\hline Aluminum & $<0.030<$ & $0.030<$ & 0.030 & 0.752 & 0.628 & 0.597 & 0.744 & 0.847 & 0.678 & $<0.150$ & $<0.150<$ & 0.150 & $<00.150<$ & 0.150 & $<0.150$ & $<0.150$ & $<0.150<$ & 0.150 \\
\hline Arsenlc & $<0.010<$ & $0.010<$ & 0.010 & $<0.050<$ & $0.050<$ & 0.050 & $<0.050<$ & $0.050<$ & 0.050 & $<0.050$ & $<0.050<$ & 0.050 & $\mid<0.050<$ & 0.050 & $<0.050$ & $<0.050$ & $<0.050<$ & 0.050 \\
\hline Boron & $<0.020<$ & $0.020<$ & 0.020 & $<0.100<$ & $0.100<$ & 0.100 & $<0.100<$ & $0.100<$ & 0.100 & $<0.100$ & $<0.100<$ & 0.100 & $<0.100<$ & $=0.100$ & $<0.100$ & 0.171 & $0.229<$ & 0.100 \\
\hline Barium & $0.001<$ & $0.001<$ & 0.001 & $<0.005<$ & $0.005<$ & 0.005 & 0.037 & 0.029 & 0.039 & 0.036 & 0.044 & 0.031 & $1<0.005<$ & $=0.005$ & $<0.005$ & 0.025 & 0.027 & 0.025 \\
\hline Beryllium & 0.002 & 0.002 & 0.002 & 0.012 & 0.012 & 0.012 & 0.013 & 0.013 & 0.013 & $<0.003$ & $<0.003<$ & 0.003 & 0.008 & 0.008 & 0.008 & 0.003 & 0.003 & 0.003 \\
\hline Calclum & $0.081<$ & $0.040<$ & 0.040 & $0.268<$ & $0.200<$ & 0.200 & 1194 & 994 & 1277 & 2360 & 2514 & 2157 & 5.882 & 3.39 & 4.811 & 14.04 & 16.21 & 15.50 \\
\hline Cadmium & $<0.001<$ & $0.001<$ & 0.001 & $<0.005<$ & $0.005<$ & 0.005 & $<0.005<$ & $0.005<$ & 0.005 & $<0.005$ & $<0.005<$ & 0.005 & $5<0.005<$ & $=0.005$ & $<0.005$ & $<0.005$ & $<0.005<$ & 0.005 \\
\hline Chromlum & $<0.005<$ & $0.005<$ & 0.005 & $<0.025<$ & $0.025<$ & 0.025 & $<0.025<$ & $0.025<$ & 0.025 & $<0.025$ & $<0.025<$ & 0.025 & $5<0.025<$ & $=0.025$ & $<0.025$ & $<0.025$ & $<0.025<$ & 0.025 \\
\hline Copper & $<0.004<$ & $0.004<$ & 0.004 & 4.399 & 3.614 & 2.815 & $<0.020<$ & $0.020<$ & 0.020 & 0.032 & 0.036 & 0.023 & $3<0.020<$ & $=0.020$ & $<0.020$ & $<0.020$ & $<0.020<$ & 0.020 \\
\hline Iron & $<0.050<$ & $0.050<$ & 0.050 & $<0.250<$ & $0.250<$ & 0.250 & 5.706 & 4.704 & 6.270 & $<0.250$ & $<0.250<$ & 0.250 & $<0.250<$ & $=0.250$ & $<0.250$ & $<0.250$ & $<0.250<$ & 0.250 \\
\hline Potassium & 5.698 & 5.427 & 5.859 & 4.496 & 4.390 & 12.65 & 12.06 & 10.87 & 11.57 & 13.99 & 7.44 & 7.56 & 8.04 & 8.75 & 5.80 & 6.41 & 7.18 & 7.84 \\
\hline Magneslum & $<0.020<$ & $0.020<$ & 0.020 & $<0.100<$ & $0.100<$ & 0.100 & 2.485 & 1.949 & 3.031 & 1.790 & 0.633 & 6.93 & 411 & 339 & 421 & 420 & 718 & 623 \\
\hline Manganese & $<0.001<$ & $0.001<$ & 0.001 & $<0.006<$ & $0.006<$ & 0.006 & 0.143 & 0.107 & 0.181 & 0.053 & $<0.006$ & 0.012 & 0.119 & 0.123 & 0.121 & 0.109 & 0.118 & 0.120 \\
\hline Sodlum & 1226 & 1125 & 1116 & 1500 & 1468 & 1479 & 1323 & 1360 & 1340 & 1488 & 1476 & 1445 & 1501 & 1449 & 1481 & 1957 & 2164 & 2117 \\
\hline Nickel & $<0.004<$ & $0.004<$ & 0.004 & $<0.020<$ & $0.020<$ & 0.020 & $0.021<$ & 0.020 & 0.023 & $<0.020$ & $<0.020<$ & 0.020 & $<<0.020<$ & $=0.020$ & $<0.020$ & $<0.020$ & $<0.020<$ & 0.020 \\
\hline Lead & $<0.007<$ & $0.007<$ & 0.007 & $<0.035<$ & $0.035<$ & 0.035 & $<0.035<$ & $0.035<$ & 0.035 & $<0.035$ & $<0.035<$ & 0.035 & $j<0.035<$ & 0.035 & $<0.035$ & $<0.035$ & $<0.035<$ & 0.035 \\
\hline Selenium & $<0.010<$ & & 0.010 & $0.051<$ & 0.050 & 0.056 & $<0.050<$ & & 0.050 & $<0.050$ & $<0.050<$ & 0.050 & $<0.050<$ & 0.050 & $<0.050$ & $<0.050$ & $<0.050<$ & 0.050 \\
\hline Antimony & $<0.010<$ & $0.010<$ & 0.010 & $<0.050<$ & $0.050<$ & 0.050 & $<0.050<$ & $0.050<$ & 0.050 & $<0.050$ & $<0.050<$ & 0.050 & $\mid<0.050<$ & 0.050 & $<0.050$ & $<0.050$ & $<0.050<$ & 0.050 \\
\hline Sillicon & 0.560 & 0.488 & 0.507 & 0.449 & 0.434 & 0.418 & 22.57 & 19.72 & 27.49 & 8.577 & 8.726 & 7.892 & 0.428 & 0.413 & 0.496 & 0.489 & 1.075 & 0.672 \\
\hline Strontlum & $<0.001<$ & $0.001<$ & 0.001 & $<0.005<$ & $0.005<$ & 0.005 & 0.339 & 0.254 & 0.368 & 0.786 & 0.847 & 0.719 & 0.018 & 0.011 & 0.015 & 0.064 & 0.073 & 0.074 \\
\hline Thorlum & $<0.130<$ & $0.130<$ & 0.130 & $<0.650<$ & $0.650<$ & 0.650 & $<0.650<$ & $0.650<$ & 0.650 & $<0.650$ & $<0.650<$ & 0.650 & $<0.650<$ & 0.650 & $<0.650$ & $<0.650$ & $<0.650<$ & 0.650 \\
\hline Tilanium & $0.001<$ & $0.001<$ & 0.001 & $<0.005<$ & $0.005<$ & 0.005 & 0.006 & 0.005 & 0.007 & 0.014 & 0.014 & 0.013 & $\mid<0.005<$ & 0.005 & $<0.005$ & $<0.005$ & $<0.005<$ & 0.005 \\
\hline Thalllum & $<0.008<$ & $0.008<$ & 0.008 & $<0.040<$ & $0.040<$ & 0.040 & $<0.040<$ & $0.040<$ & 0.040 & 0.042 & $0.064<$ & 0.040 & $<0.040<$ & 0.040 & $<0.040$ & $<0.040$ & $<0.040<$ & 0.040 \\
\hline Uranlum & $<0.050$ & $0.054<$ & 0.050 & $<0.250<$ & $0.250<$ & 0.250 & $<0.250<$ & $0.250<$ & 0.250 & 0.277 & $<0.250$ & 0.304 & $<0.250<$ & 0.250 & $<0.250$ & $<0.250$ & $<0.250<$ & 0.250 \\
\hline Vanadlum & $<0.010<$ & $0.010<$ & 0.010 & $<0.050<$ & $0.050<$ & 0.050 & $<0.050<$ & $0.050<$ & 0.050 & $<0.050$ & $<0.050<$ & 0.050 & $\mid<0.050<$ & 0.050 & $<0.050$ & $<0.050$ & $<0.050<$ & 0.050 \\
\hline Zinc & 0.011 & 0.006 & 0.005 & $<0.025<$ & $0.025<$ & 0.025 & 0.250 & 1.478 & 2.178 & $<0.025$ & 0.050 & 0.103 & 44.67 & 105.6 & 50.96 & 0.09 & 75.69 & 98.29 \\
\hline Zlrconium & $<0.010<$ & $0.010<$ & 0.010 & $<0.050<$ & $0.050<$ & 0.050 & $<0.050<$ & $0.050<$ & 0.050 & $<0.050$ & $0.067<$ & 0.050 & 0.060 & 0.089 & 0.066 & $<0.050$ & 0.079 & 0.106 \\
\hline Mercury & 0.145 & 0.104 & 0.072 & 3876 & 2985 & 2473 & 58.0 & 63.20 & 89.60 & 205 & 13 & 157 & 50.50 & 46.30 & 6.00 & 34.5 & 136 & 104 \\
\hline
\end{tabular}

${ }^{a}$ Results in micrograms per liter. 
Table A.11. Leaching results (milligrams per liter) obtained at 2 months - pH 7

\begin{tabular}{|c|c|c|c|c|c|c|c|c|c|c|c|c|c|c|c|c|c|c|c|}
\hline & Blk-P & BIk-Q & Blk-R & HG-P & HG-Q & HG-R & Lanl-32 & Lanl-33 & & Lan1-34 & Fern-40 & Fern-41 & Fern-42 & OR-40 & OR-41 & OR-42 & ID-26 & $10-27$ & ID-30 \\
\hline $\begin{array}{l}\text { Weight(g) } \\
\text { Inltial pH }\end{array}$ & 7.55 & 7.55 & 8.06 & $\begin{array}{l}13.00 \\
7.55\end{array}$ & $\begin{array}{l}6.00 \\
7.55\end{array}$ & $\begin{array}{l}8.00 \\
7.55\end{array}$ & $\begin{array}{l}19.31 \\
8.06\end{array}$ & $\begin{array}{l}14.65 \\
8.06\end{array}$ & & $\begin{array}{l}23.92 \\
8.06\end{array}$ & $\begin{array}{l}14.84 \\
8.06\end{array}$ & $\begin{array}{l}19.31 \\
8.06\end{array}$ & $\begin{array}{l}27.06 \\
8.06\end{array}$ & $\begin{array}{l}8.83 \\
8.06\end{array}$ & $\begin{array}{l}7.14 \\
8.06\end{array}$ & $\begin{array}{l}8.34 \\
8.06\end{array}$ & $\begin{array}{l}12.15 \\
8.06\end{array}$ & $\begin{array}{l}12.33 \\
8.06\end{array}$ & $\begin{array}{l}21.36 \\
8.06\end{array}$ \\
\hline Final pH & 7.60 & 5.78 & 5.94 & 7.13 & 6.83 & 6.89 & 7.44 & 7.25 & & 6.51 & 7.90 & 9.35 & 9.77 & 10.73 & 10.70 & 10.71 & 10.74 & 10.66 & 10.53 \\
\hline Sllver & $<0.003<$ & $0.003<$ & 0.003 & $<0.013<$ & $0.013<$ & 0.013 & $<0.013<$ & 0.013 & $<$ & 0.013 & $<0.013<$ & 0.013 & 0.022 & $<0.013<$ & 0.013 & $<0.013$ & $<0.013<$ & 0.013 & 0.013 \\
\hline Aluminum & 0.074 & 0.085 & 0.066 & 0.481 & 0.446 & 0.466 & 0.319 & 0.256 & & 0.536 & $<0.150$ & 0.266 & 0.151 & 0.289 & 0.270 & 0.256 & $<0.150<$ & $0.150<$ & 0.150 \\
\hline Arsenlc & $<0.010<$ & $0.010<$ & 0.010 & $<0.050<$ & $0.050<$ & 0.050 & $<0.050<$ & 0.050 & $<$ & 0.050 & $<0.050$ & $0.069<$ & 0.050 & $<0.050<$ & 0.050 & $<0.050$ & $<0.050<$ & $0.050<$ & 0.050 \\
\hline Boron & $<0.020<$ & $0.020<$ & 0.020 & $<0.100<$ & $0.100<$ & 0.100 & $<0.100<$ & 0.100 & $<$ & 0.100 & $<0.100<$ & $0.100<$ & 0.100 & 0.156 & 0.155 & 0.136 & 1.027 & 1.100 & 0.973 \\
\hline Barium & $<0.001<$ & 0.001 & 0.001 & $<0.005<$ & $0.005<$ & 0.005 & 0.040 & 0.023 & & 0.040 & 0.025 & 0.030 & 0.043 & $<0.005<$ & 0.005 & $<0.005$ & 0.013 & 0.015 & 0.017 \\
\hline Beryllium & 0.002 & 0.002 & 0.002 & 0.012 & 0.012 & 0.012 & 0.006 & 0.006 & & 0.013 & 0.003 & 0.004 & 0.005 & 0.008 & 0.009 & 0.009 & 0.005 & 0.005 & 0.006 \\
\hline Calclum & $<0.040<$ & $0.040<$ & 0.040 & $<0.200<$ & $0.200<$ & 0.200 & 1628 & 1044 & & 1770 & 1970 & 2647 & 4010 & 1.670 & 1.143 & 1.396 & 6.907 & 6.772 & 9.372 \\
\hline Cadmlum & $<0.001<$ & 0.001 & 0.001 & $<0.005<$ & $0.005<$ & 0.005 & $<0.005<$ & 0.005 & $<$ & 0.005 & $<0.005<$ & $0.005<$ & 0.005 & $<0.005<$ & 0.005 & $<0.005$ & $<0.005<$ & 0.005 & 0.005 \\
\hline Chromium & $<0.005<$ & 0.005 & 0.005 & $<0.025<$ & $0.025<$ & 0.025 & $<0.025<$ & 0.025 & $<$ & 0.025 & $<0.025<$ & $0.025<$ & 0.025 & $<0.025<$ & 0.025 & $<0.025$ & $<0.025<$ & $0.025<$ & 0.025 \\
\hline Copper & $<0.004<$ & $0.004<$ & 0.004 & 0.638 & 0.469 & 0.549 & $<0.020<$ & 0.020 & & 0.026 & 0.037 & 0.050 & 0.075 & $<0.020<$ & 0.020 & $<0.020$ & $<0.020<$ & $0.020<$ & 0.020 \\
\hline Iron & $<0.050<$ & $0.050<$ & 0.050 & $<0.250<$ & $0.250<$ & 0.250 & $<0.250<$ & 0.250 & $<$ & 0.250 & $<0.250<$ & $0.250<$ & 0.250 & $<0.250<$ & 0.250 & $<0.250$ & $<0.250<$ & $0.250<$ & 0.250 \\
\hline Potassium & 4.612 & 5.204 & 6.054 & 11.93 & 6.782 & 4.190 & 9.380 & 7.49 & & 10.44 & 9.318 & 12.31 & 7.298 & 7.131 & 5.508 & 13.70 & 8.091 & 9.21 & 11.52 \\
\hline Magnesium & $<0.020<$ & $0.020<$ & 0.020 & $<0.100<$ & $0.100<$ & 0.100 & 1.643 & 0.879 & & 1.545 & 0.517 & 0.347 & 0.803 & 17.01 & 16.44 & 16.03 & 22.98 & 29.7 .1 & 52.55 \\
\hline Manganese & $<0.001<$ & $0.001<$ & 0.001 & $<0.006<$ & $0.006<$ & 0.006 & 0.122 & 0.129 & & 0.011 & $<0.006<$ & $0.006<$ & 0.006 & 0.118 & 0.117 & 0.116 & 0.111 & 0.111 & 0.106 \\
\hline Sodium & $<0.060<$ & 0.060 & 0.060 & $0.641<$ & 0.300 & 0.300 & 13.45 & 8.15 & & 14.8 & 28.34 & 38.18 & 53.53 & 178 & 124 & 163 & 1545 & 1430 & 2621 \\
\hline Nickel & $<0.004<$ & 0.004 & 0.004 & $<0.020<$ & 0.020 & 0.020 & $<0.020<$ & 0.020 & $<$ & 0.020 & $<0.020<$ & 0.020 & 0.025 & $<0.020<$ & 0.020 & $<0.020$ & $<0.020<$ & $0.020<$ & 0.020 \\
\hline Lead & $<0.007<$ & $0.007<$ & 0.007 & $<0.035<$ & $0.035<$ & 0.035 & $<0.035<$ & 0.035 & $<$ & 0.035 & $<0.035<$ & $0.035<$ & 0.035 & $<0.035<$ & 0.035 & $<0.035$ & $<0.035<$ & $0.035<$ & 0.035 \\
\hline Selenlum & 0.020 & 0.018 & 0.016 & 0.079 & 0.066 & 0.073 & $<0.050<$ & 0.050 & & 0.065 & $<0.050<$ & $0.050<$ & 0.050 & $<0.050<$ & 0.050 & $<0.050$ & $<0.050<$ & $0.050<$ & 0.050 \\
\hline Antimony & $<0.010<$ & $0.010<$ & 0.010 & $<0.050<$ & $0.050<$ & 0.050 & $<0.050<$ & 0.050 & $<$ & 0.050 & $<0.050<$ & $0.050<$ & 0.050 & $<0.050<$ & 0.050 & $<0.050$ & $<0.050<$ & $0.050<$ & 0.050 \\
\hline Sillicon & 0.507 & 0.498 & 0.467 & 0.437 & 0.444 & 0.446 & 29.38 & 14.05 & & 22.69 & 6.853 & 9.210 & 10.60 & 0.389 & 0.363 & 0.438 & 0.834 & 0.889 & 0.964 \\
\hline Strontium & $<0.001<$ & $0.001<$ & 0.001 & $<0.005<$ & $0.005<$ & 0.005 & 0.572 & 0.320 & & 0.608 & 0.572 & 0.833 & 1.353 & $0.005<$ & 0.005 & $<0.005$ & 0.051 & 0.047 & 0.076 \\
\hline Thorium & $<0.130<$ & $0.130<$ & 0.130 & $<0.650<$ & $0.650<$ & 0.650 & $<0.650<$ & 0.650 & $<$ & 0.650 & $<0.650<$ & $0.650<$ & 0.650 & $<0.650<$ & 0.650 & $<0.650$ & $<0.650<$ & $0.650<$ & 0.650 \\
\hline Titan & $<0.001<$ & 0.001 & 0.001 & $<0.005<$ & $0.005<$ & 0.005 & $0.007<$ & 0.005 & & 0.009 & 0.011 & 0.014 & 0.017 & $<0.005<$ & 0.005 & $<0.005$ & $<0.005<$ & $0.005<$ & 0.005 \\
\hline Thallium & $<0.008<$ & $0.008<$ & 0.008 & $<0.040<$ & $0.040<$ & 0.040 & $<0.040<$ & 0.040 & $<$ & 0.040 & 0.114 & 0.071 & 0.159 & $<0.040<$ & 0.040 & $<0.040$ & $<0.040<$ & $0.040<$ & 0.040 \\
\hline Uranium & $0.055<$ & 0.050 & 0.059 & $<0.250<$ & $0.250<$ & 0.250 & $<0.250<$ & 0.250 & $<$ & 0.250 & $<0.250<$ & $0.250<$ & 0.250 & $<0.250<$ & 0.250 & $<0.250$ & $<0.250<$ & $0.250<$ & 0.250 \\
\hline Vanadlum & $<0.010<$ & $0.010<$ & 0.010 & $<0.050<$ & $0.050<$ & 0.050 & $<0.050<$ & 0.050 & $<$ & 0.050 & 0.066 & 0.056 & 0.154 & $<0.050<$ & 0.050 & $<0.050$ & $<0.050<$ & $0.050<$ & 0.050 \\
\hline Zinc & $<0.005<$ & 0.005 & 0.005 & $<0.025<$ & $0.025<$ & 0.025 & $<0.025$ & 0.227 & $<$ & 0.025 & 0.053 & 0.026 & 0.061 & 0.167 & 0.144 & 0.244 & 0.241 & 0.088 & 0.060 \\
\hline Zirconlum & $<0.010<$ & 0.010 & 0.010 & $<0.050<$ & $0.050<$ & 0.050 & $<0.050<$ & 0.050 & $<$ & 0.050 & 0.062 & 0.064 & 0.118 & $<0.050<$ & 0.050 & $<0.050$ & $<0.050<$ & $0.050<$ & 0.050 \\
\hline Mercury & $<0.050<$ & $0.050<$ & 0.050 & 3107 & 203 & 803 & 0.930 & 1.900 & & 153.0 & 48.7 & 95.2 & 599 & $<0.050<$ & 0.050 & $<0.050$ & 13.70 & 8.43 & 10.40 \\
\hline
\end{tabular}

${ }^{\mathrm{a}}$ Results in micrograms per liter. 
Table A.12. Leaching results (milligrams per liter) obtained at 2 months - pH 12.5

\begin{tabular}{|c|c|c|c|c|c|c|c|c|c|c|c|c|c|c|c|c|c|c|}
\hline & BIk-V & Blk-W & Blk-X & HG-13 & HG-19 & HG-21 & 1 Lanl-16 & 6 Lanl-17 & 7 Lanl-18 & Fern-25 & 25 Fern-26 & 6 Fern-27 & OR-23 & OR-24 & OR-25 & ID-15 & ID-15A & ID-20A \\
\hline $\begin{array}{l}\text { Weight(g) } \\
\text { Inllial pH }\end{array}$ & 12.68 & 12.48 & 12.48 & $\begin{array}{l}6.10 \\
12.68\end{array}$ & $\begin{array}{l}4.24 \\
12.68\end{array}$ & $\begin{array}{l}13.40 \\
12.68\end{array}$ & $\begin{array}{l}11.20 \\
12.48\end{array}$ & $\begin{array}{l}11.32 \\
12.48\end{array}$ & $\begin{array}{l}17.50 \\
12.48\end{array}$ & $\begin{array}{l}19.51 \\
12.48\end{array}$ & $\begin{array}{l}23.31 \\
12.48\end{array}$ & $\begin{array}{l}19.99 \\
12.48\end{array}$ & $\begin{array}{l}7.30 \\
12.48\end{array}$ & $\begin{array}{l}8.93 \\
12.48\end{array}$ & $\begin{array}{l}8.73 \\
12.48\end{array}$ & $\begin{array}{l}3.78 \\
12.68\end{array}$ & $\begin{array}{l}6.64 \\
12.68\end{array}$ & $\begin{array}{l}3.89 \\
12.48\end{array}$ \\
\hline Final pH & 12.73 & 12.75 & 12.74 & 12.74 & 12.74 & 12.71 & 11.77 & 9.90 & 10.32 & 10.30 & 10.22 & 10.29 & 12.12 & 12.42 & 12.21 & 12.74 & 12.70 & 12.72 \\
\hline Silver & $<0.003<$ & $<0.003$ & $<0.003$ & $0.022<$ & $<0.013$ & $<0.013$ & $<0.013<$ & $<0.013$ & $<0.013$ & $<0.013$ & 0.051 & 0.017 & $<0.013$ & $<0.013<$ & $<0: 013$ & 0.058 & $<0.013$ & $<0.013$ \\
\hline Aluminum & 0.083 & 0.094 & 0.089 & 0.498 & 0.482 & 0.505 & 0.566 & 0.512 & 0.550 & 0.410 & 0.281 & $<0.150$ & 0.271 & 0.213 & 0.213 & $<0.150<$ & $<0.150$ & 0.156 \\
\hline Arsenic & $0.015<$ & $<0.010$ & $<0.010$ & $<0.050<$ & $<0.050$ & $<0.050$ & $<0.050<$ & $<0.050$ & $<0.050$ & $<0.050$ & $<0.050$ & $<0.050$ & $<0.050$ & $<0.050<$ & $=0.050$ & $<0.050<$ & $<0.050$ & $<0.050$ \\
\hline Boron & $<0.020<$ & $<0.020$ & $<0.020$ & $<0.100<$ & $<0.100$ & $<0.100$ & $<0.100<$ & $<0.100$ & $<0.100$ & $<0.100$ & $<0.100$ & $<0.100$ & 0.244 & 0.301 & 0.295 & 1.200 & 2.115 & 1.439 \\
\hline Barlum & 0.013 & 0.016 & 0.016 & 0.012 & 0.011 & 0.013 & 0.074 & 0.078 & 0.109 & 0.039 & 0.040 & 0.037 & 0.016 & 0.016 & 0.015 & 0.059 & 0.053 & 0.048 \\
\hline Beryllium & 0.002 & 0.002 & 0.002 & 0.012 & 0.012 & 0.012 & 0.012 & 0.012 & 0.013 & 0.008 & $<0.003$ & $<0.003$ & 0.007 & 0.007 & 0.007 & 0.003 & 0.003 & 0.004 \\
\hline Calclum & 974 & 965 & 981 & 970 & 974 & 968 & 1461 & 1529 & 1839 & 4544 & 4821 & 4477 & 446 & 709 & 610 & 1060 & 1031 & 1080 \\
\hline Cadmium & $<0.001<$ & $<0.001$ & $<0.001$ & $<0.005<$ & $<0.005$ & $<0.005$ & $<0.005$ & $<0.005$ & $<0.005$ & $<0.005$ & $<0.005$ & $<0.005$ & $<0.005$ & $<0.005<$ & 0.005 & $<0.005<$ & $<0.005$ & $<0.005$ \\
\hline Chromium & 0.018 & 0.024 & 0.022 & $<0.025<$ & $<0.025$ & $<0.025$ & $<0.025<$ & $<0.025$ & $<0.025$ & $<0.025$ & 0.048 & $<0.025$ & $<0.025$ & $<0.025<$ & 0.025 & $<0.025<$ & $<0.025$ & $<0.025$ \\
\hline Copper & 0.012 & 0.016 & 0.015 & 0.238 & 0.128 & 0.339 & 0.062 & 0.025 & 0.024 & 0.077 & 0.108 & 0.102 & $<0.020$ & $0.024<$ & 0.020 & $<0.020<$ & $<0.020$ & $<0.020$ \\
\hline Iron & $<0.050<$ & $<0.050$ & $<0.050$ & $<0.250<$ & $<0.250$ & $<0.250$ & $<0.250<$ & $<0.250$ & $<0.250$ & $<0.250$ & $<0.250$ & $<0.250$ & $<0.250$ & $<0.250<$ & $=0.250$ & $<0.250<$ & $<0.250$ & $<0.250$ \\
\hline Potasslum & 3.705 & 19.013 & $3 \quad 2.722$ & 3.610 & 3.885 & 4.338 & 9.258 & 9.974 & 10.39 & 27.96 & 8.375 & 6.875 & 10.02 & 20.92 & 7.70 & 6.324 & 10.258 & 5.890 \\
\hline Magnesium & $<0.020<$ & $<0.020$ & $<0.020$ & $<0.100<$ & $<0.100$ & $<0.100$ & $<0.100<$ & $<0.100$ & 0.135 & 0.738 & 1.154 & 0.659 & $<0.100$ & $<0.100<$ & $=0.100$ & $<0.100<$ & $<0.100$ & 0.151 \\
\hline Manganese & $<0.001<$ & $<0.001$ & $<0.001$ & $<0.006<$ & $<0.006$ & $<0.006$ & $<0.006<$ & $<0.006$ & $<0.006$ & $<0.006$ & $<0.006$ & $<0.006$ & 0.117 & 0.116 & 0.115 & 0.113 & 0.111 & 0.113 \\
\hline Sodlum & 1.009 & 0.654 & 0.564 & 0.629 & 0.462 & 0.458 & 8.287 & 8.046 & 11.80 & 42.90 & 46.86 & 38.39 & 151 & 169 & 185 & 395 & 698 & 480 \\
\hline Nlckel & $<0.004<$ & $<0.004$ & $<0.004$ & $<0.020<$ & $<0.020$ & $<0.020$ & $<0.020<$ & $<0.020$ & $<0.020$ & 0.033 & 0.036 & 0.026 & $<0.020$ & $<0.020<$ & $=0.020$ & $<0.020<$ & $<0.020$ & $<0.020$ \\
\hline Lead & $<0.007<$ & $<0.007$ & $<0.007$ & $<0.035<$ & $<0.035$ & $<0.035$ & $<0.035<$ & $<0.035$ & $<0.035$ & $<0.035$ & $<0.035$ & $<0.035$ & $<0.035$ & $<0.035<$ & 0.035 & $<0.035<$ & $<0.035$ & $<0.035$ \\
\hline Selenium & $<0.010<$ & $<0.010$ & 0.011 & 0.095 & 0.079 & 0.073 & 0.069 & 0.069 & 0.081 & $<0.050$ & $<0.050$ & $<0.050$ & $<0.050$ & $<0.050<$ & $=0.050$ & $<0.050<$ & $<0.050$ & $<0.050$ \\
\hline Antimony & $<0.010<$ & $<0.010$ & $<0.010$ & $<0.050<$ & $<0.050$ & $<0.050$ & $<0.050<$ & $<0.050$ & $<0.050$ & $<0.050$ & 0.061 & $<0.050$ & $<0.050$ & $<0.050<$ & 0.050 & $<0.050<$ & $<0.050$ & $<0.050$ \\
\hline Sillicon & 0.682 & 0.779 & 0.822 & 0.850 & 0.554 & 0.655 & 1.925 & 3.923 & 7.914 & 4.220 & 5.617 & 3.552 & 1.194 & 0.822 & 0.882 & 1.547 & 1.763 & 1.600 \\
\hline Strontlum & 0.731 & 0.848 & 0.854 & 0.487 & 0.496 & 0.513 & 1.010 & 1.021 & 1.224 & 2.019 & 2.208 & 2.001 & 0.668 & 0.659 & 0.669 & 0.750 & 0.836 & 0.845 \\
\hline Thorlum & $<0.130<$ & $<0.130$ & $<0.130$ & $<0.650<$ & $<0.650$ & $<0.650$ & $<0.650<$ & $<0.650$ & $<0.650$ & $<0.650$ & $<0.650$ & $<0.650$ & $<0.650$ & $<0.650<$ & $=0.650$ & $<0.650<$ & $<0.650$ & $<0.650$ \\
\hline Tilanium & 0.005 & 0.005 & 0.005 & 0.006 & 0.006 & $<0.005$ & 0.008 & 0.008 & 0.009 & 0.018 & 0.021 & 0.017 & $<0.005$ & $<0.005<$ & 0.005 & 0.005 & 0.005 & $<0.005$ \\
\hline Thallum & $<0.008<$ & $<0.008$ & $<0.008$ & $<0.040<$ & $<0.040$ & $<0.040$ & $<0.040<$ & $<0.040$ & $<0.040$ & 0.134 & 0.145 & 0.104 & $<0.040$ & $<0.040<$ & $=0.040$ & $<0.040<$ & $<0.040$ & $<0.040$ \\
\hline Uranlum & 0.056 & 0.050 & 0.065 & $<0.250<$ & $<0.250$ & $<0.250$ & $<0.250<$ & $<0.250$ & $<0.250$ & $<0.250$ & $<0.250$ & $<0.250$ & $<0.250$ & $<0.250<$ & 0.250 & $<0.250<$ & $<0.250$ & $<0.250$ \\
\hline Vanadlum & $<0.010<$ & $<0.010$ & $<0.010$ & $<0.050<$ & $<0.050$ & $<0.050$ & $<0.050<$ & $<0.050$ & $<0.050$ & 0.163 & 0.241 & 0.176 & $<0.050$ & $0.062<$ & 0.050 & $<0.050<$ & $<0.050$ & $<0.050$ \\
\hline Zinc & $<0.005<$ & $<0.005$ & $<0.005$ & $<0.025<$ & $<0.025$ & $<0.025$ & $<0.025<$ & $<0.025$ & $<0.025$ & 0.037 & 0.047 & 0.031 & 1.052 & 2.404 & 1.310 & 2.271 & 2.187 & 2.486 \\
\hline Zirconlum & $<0.010<$ & $<0.010$ & $<0.010$ & $<0.050<$ & 0.050 & $<0.050$ & $<0.050<$ & $<0.050$ & $<0.050$ & 0.224 & 0.194 & 0.193 & $<0.050$ & $<0.050<$ & 0.050 & $<0.050<$ & $<0.050$ & 0.056 \\
\hline Mercury & $1.354<$ & $<0.050$ & $<0.050$ & 6791 & 6499 & 311 & 8.00 & 15.00 & 15.50 & 1027 & 1630 & 1011 & 8.50 & 22.60 & 11.60 & 839 & 214 & 166 \\
\hline
\end{tabular}

${ }^{a}$ Results in micrograms per liter. 
Table A.13. Leaching results (milligrams per liter) obtained at 3 months - pH 3

\begin{tabular}{|c|c|c|c|c|c|c|c|c|c|c|c|c|c|c|c|c|c|c|}
\hline & B|k-G & Blk-H & Blk-1 & HG-2 & HG-7 & HG-3 & LANL- & 28 LANL & 29 LANL & 30 Fern-34 & Fern-3 & 35 Fern- & 6 OR-46 & OR-47 & OR-48 & ID-21 & ID-23 & ID-23A \\
\hline $\begin{array}{l}\text { Weight(g } \\
\text { Initlal pH }\end{array}$ & 2.85 & 3.05 & 3.05 & $\begin{array}{l}4.52 \\
2.85\end{array}$ & $\begin{array}{l}6.81 \\
2.85\end{array}$ & $\begin{array}{l}7.70 \\
2.85\end{array}$ & $\begin{array}{l}19.15 \\
3.05\end{array}$ & $\begin{array}{l}12.92 \\
3.05\end{array}$ & $\begin{array}{l}12.29 \\
3.05\end{array}$ & $\begin{array}{l}14.71 \\
3.05\end{array}$ & $\begin{array}{l}19.52 \\
3.05\end{array}$ & $\begin{array}{l}14.09 \\
3.05\end{array}$ & $\begin{array}{l}10.20 \\
3.05\end{array}$ & $\begin{array}{l}7.30 \\
3.05\end{array}$ & $\begin{array}{l}11.15 \\
3.05\end{array}$ & $\begin{array}{l}7.59 \\
3.05\end{array}$ & $\begin{array}{l}6.10 \\
2.85\end{array}$ & $\begin{array}{l}4.53 \\
2.85\end{array}$ \\
\hline & 2.77 & 2.81 & 2.89 & 2.90 & 2.92 & 2.92 & 3.92 & 3.77 & 3.80 & 4.84 & 4.80 & 4.49 & 6.17 & 6.13 & 7.31 & 9.68 & 8.70 & 7.86 \\
\hline & & $<0.003$ & $<0.003$ & $<0.005$ & $<0.005$ & 0.005 & $<0.005$ & $<0.005$ & $<0.005$ & $<0.005$ & $<0.0$ & $<0.005$ & 0.005 & 55. & .005 & 0.005 & 0.005 & .005 \\
\hline & $<0.030$ & .030 & $<0.030$ & 0.060 & $<0.060$ & 0.064 & 6.599 & 6.077 & 7.285 & 0.158 & 0.146 & 0.131 & 0.060 & .060 & 1.060 & $<0.060$ & .060 & .060 \\
\hline & .010 & & $<0.010$ & $<0.020$ & $<0.020$ & $<0.020$ & $<0.020$ & $<0.020$ & $<0.020$ & 0.023 & $<0.020$ & $<0.020$ & 0.020 & $<0.020$ & $<0.020$ & $<0.020$ & $<0.020$ & $<0.020$ \\
\hline & $<0.020$ & 020 & $<0.020$ & 1.168 & 0.172 & 2.167 & 0.180 & 0.146 & 0.134 & 0.164 & 0.162 & 0.148 & 0.465 & 0.399 & 0.433 & 0.909 & 0.966 & 1.038 \\
\hline & $<0.001$ & & $<0.001$ & $<0.002$ & $<0.002$ & 0.002 & 0.041 & 0.030 & 0.034 & 0.026 & 0.028 & 0.018 & 0.003 & 0.003 & 0.005 & 0.027 & 0.036 & 0.044 \\
\hline & 0.001 & & 0.001 & $<0.001$ & $<0.001$ & $<0.001$ & $<0.001$ & $<0.001$ & $<0.001$ & $<0.001$ & $<0.001$ & $<0.001$ & $<0.001$ & $<0.001$ & $<0.001$ & $<0.001$ & $<0.001$ & $<0.001$ \\
\hline & & & 0.040 & $<0.080$ & 0.398 & 0.145 & 1624 & 1204 & 1174 & 2262 & 2550 & 1642 & 4.82 & 3.59 & 6.32 & 14.32 & 13.44 & 11.88 \\
\hline & $<0.001$ & & $<0.001$ & $<0.002$ & $<0.002$ & $<0.002$ & $<0.002$ & $<0.002$ & $<0.002$ & $<0.002$ & $<0.002$ & $<0.002$ & .002 & $<0.002$ & $<0.002$ & $<0.002$ & $<0.002$ & 0.002 \\
\hline & $<0.005$ & & $<0.005$ & $<0.010$ & $<0.010$ & $<0.010$ & 0.035 & 0.033 & 0.028 & 0.014 & 0.018 & 0.014 & & 0.010 & 0.010 & $<0.010$ & 0.010 & 0.010 \\
\hline & & & $<0.004$ & 1.129 & 1.587 & 1.872 & $<0.008$ & $<0.008$ & & $<0.008$ & $<0.008$ & $<0.008$ & & $<0.008$ & $<0.008$ & $<0.008$ & $<0.008$ & $<0.008$ \\
\hline & $\begin{array}{r}<0.0 \\
3.8\end{array}$ & & $\begin{array}{c}<0.050 \\
1.61\end{array}$ & $\begin{array}{r}<0.100 \\
1.333\end{array}$ & $\begin{array}{r}<0.100 \\
1.615\end{array}$ & $\begin{array}{r}<.100 \\
2.240\end{array}$ & & & & & & & & & & & & \\
\hline & & & $<0.020$ & $<0.040$ & $<0.040$ & $<0.040$ & 4.447 & 4.058 & 178 & 8.9 & 11 & 8.814 & 96 & 716 & 1069 & 1229 & 1430 & 1380 \\
\hline & $<0.001$ & $<0.001$ & $<0.001$ & 0.002 & $<0.002$ & $<0.002$ & 0.252 & 0.178 & 0.658 & 0.026 & 0.0 & 0.030 & 67 & 0.063 & 0.076 & $<0.002$ & $<0.002$ & 0.008 \\
\hline & 1.106 & 0.363 & 0.143 & 0.120 & $<0.120$ & $<0.120$ & 12.73 & 8.283 & & 26.96 & 34.66 & 25.72 & 24 & 228 & 236 & 659 & 654 & 530 \\
\hline & $<0.004$ & 0.005 & $<0.004$ & $<0.008$ & $<$ & $<$ & 0.043 & 30 & & 0.008 & $<0.008$ & $<0.008$ & $<0.008$ & $<0.008$ & $<0.008$ & $<0.008$ & $<0.008$ & 008 \\
\hline & & $<0.007$ & $<0.007$ & $<0.014$ & .014 & $<0.014$ & $<0.014$ & 014 & $<0.014$ & 0.014 & $<0.014$ & $<0.014$ & $<0.014$ & $<0.014$ & $<0.014$ & 014 & $<$ & 014 \\
\hline & & & $<0.010$ & 0.022 & $<0.020$ & 0.027 & $<0.020$ & .020 & $<0.020$ & $<0.020$ & $<0.020$ & $<0.020$ & 0.021 & 0.023 & $<0.020$ & $<0.020$ & $<0.020$ & 0.022 \\
\hline & $<0.010$ & $<0.010$ & $<0.010$ & $<0.020$ & $<0.020$ & $<0.020$ & $<0.020$ & $<0.020$ & $<0.020$ & $<0.020$ & $<0.020$ & $<0.020$ & $<0.020$ & 0.022 & $<0.020$ & $<0.020$ & 0.027 & 0.020 \\
\hline & & 0.047 & 0.402 & 8.907 & 0.549 & 36.31 & 40.62 & 28.99 & 33.37 & 6.652 & 8.438 & 6.501 & 997 & 0.068 & 0.516 & 0.552 & 0.723 & 0.073 \\
\hline & $<0.001$ & $<0.001$ & $<0.001$ & $<0.002$ & $<0.002$ & $<0.002$ & 0.726 & 0.479 & 0.480 & 0.844 & 1.080 & 0.683 & 0.014 & $\quad 0.011$ & 0.017 & 0.049 & 0.046 & 0.041 \\
\hline & & & $<0.130$ & $<0.260$ & 0.340 & $<0.260$ & $<0.260$ & $<0.260$ & $<0.260$ & 0.448 & 0.516 & $<0.260$ & $<0.260$ & $<0.260$ & $<0.260$ & $<0.260$ & $<0.260$ & $<0.260$ \\
\hline & $<0.001$ & $<0.001$ & $<0.001$ & $<0.002$ & $<0.002$ & $<0.002$ & $<0.002$ & $<0.002$ & $<0.002$ & $<0.002$ & $<0.002$ & $<0.002$ & $<0.002$ & $<0.002$ & $<0.002$ & $<0.002$ & $<0.002$ & $<0.002$ \\
\hline & & $<0.008$ & $<0.008$ & $<0.016$ & $<0.016$ & $<0.016$ & $<0.016$ & $<0.016$ & 0.016 & $<0.016$ & $<0.016$ & $<0.016$ & $<0.016$ & $<0.016$ & $<0.016$ & $<0.016$ & $<0.016$ & $<0.016$ \\
\hline & & 0.062 & 0.080 & $<0.100$ & 0.138 & $<0.100$ & $<0.100$ & $<0.100$ & $<0.100$ & 0.295 & 0.336 & 0.165 & $<0.100$ & $<0.100$ & 0.105 & $<0.100$ & $<0.100$ & $<0.100$ \\
\hline & & $<0.010$ & $<0.010$ & $<0.020$ & $<0.020$ & $<0.020$ & 0.042 & 0.032 & 0.039 & $<0.020$ & 0.020 & $<0.020$ & $<0.020$ & $<0.020$ & $<0.020$ & $<0.020$ & 0.040 & $<0.020$ \\
\hline & & & $<0.005$ & 0.013 & 0.023 & 0.025 & 0.804 & 0.200 & & 0.040 & 0.031 & 0.038 & 107.9 & 125.9 & 96.7 & 0.1 & 2.3 & 35.3 \\
\hline & $<0.010$ & $<0.010$ & $<0.010$ & $<0.020$ & $<0.020$ & $<0.020$ & $<0.020$ & $<0.020$ & $<0.020$ & $<0.020$ & $<0.020$ & $<0.020$ & $<0.020$ & $<0.020$ & $<0.020$ & 0.031 & 0.061 & 0.071 \\
\hline Mercury & 0.426 & 0.130 & 0.139 & 3929 & 4230 & 4611 & 3.950 & 3.890 & 9.750 & 77.6 & 91.0 & 72.0 & 42.1 & 23.9 & 121.5 & 3.03 & $12 . .6$ & 8.9 \\
\hline
\end{tabular}

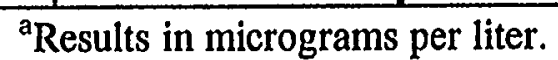


Table A.14. Leaching results (milligrams per liter) obtained at 3 months - pH 5

\begin{tabular}{|c|c|c|c|c|c|c|c|c|c|c|c|c|c|c|c|c|c|c|}
\hline & Blk-D & Blk-E & Blk-F & HG-D & HG-E & HG-F & Lanl-22 & 2 Lanl-2 & Lanl-24 & 4 Forn-3 & 31 Fern-32 & Fern-33 & 3 OR-34 & OR-35 & OR. & ID. & ID-18A & ID-19 \\
\hline $\begin{array}{l}\text { Welght(g) } \\
\text { Inltial pH }\end{array}$ & 4.63 & 4.89 & 4.89 & $\begin{array}{l}11.00 \\
4.63\end{array}$ & $\begin{array}{l}10.00 \\
4.63\end{array}$ & $\begin{array}{l}13.00 \\
4.63\end{array}$ & $\begin{array}{l}9.74 \\
4.89\end{array}$ & $\begin{array}{l}14.65 \\
4.89\end{array}$ & $\begin{array}{l}11.90 \\
4.89\end{array}$ & $\begin{array}{l}23.17 \\
4.89\end{array}$ & $\begin{array}{l}18.48 \\
4.89\end{array}$ & $\begin{array}{l}14.75 \\
4.89\end{array}$ & $\begin{array}{l}11.10 \\
4.89\end{array}$ & $\begin{array}{l}10.45 \\
4.89\end{array}$ & $\begin{array}{l}7.66 \\
4.89\end{array}$ & $\begin{array}{l}4.78 \\
4.89\end{array}$ & $\begin{array}{l}4.63 \\
4.89\end{array}$ & $\begin{array}{l}5.28 \\
4.63\end{array}$ \\
\hline Final pH & 4.65 & 4.91 & 4.91 & 4.79 & 4.80 & 4.79 & 5.17 & 5.23 & 5.19 & 7.63 & 7.24 & 7.26 & 9.10 & 6.45 & 6.36 & 6.71 & 9.91 & 6.14 \\
\hline Sllver & $<0.003$ & $<0.003$ & .003 & $<0.005$ & $<0.005$ & $<0.005$ & 0.024 & $<0.005$ & $<0.005$ & $<0.005$ & $<0.005$ & $<0.005$ & $<0.005$ & $<0.005$ & $<0.005$ & $<0.005$ & $<0.005$ & $<0.005$ \\
\hline AlumInum & $<0.030$ & $<0.030$ & $<0.030$ & 0.207 & 0.154 & 0.253 & 0.083 & 0.121 & 0.279 & $<0.060$ & $<0.060$ & $<0.060$ & $<0.060$ & $<0.060$ & $<0.060$ & $<0.060$ & $<0.060$ & $<0.060$ \\
\hline Arsenic & $<0.010$ & $<0.010$ & $<0.010$ & $<0.020$ & $<0.020$ & $<0.020$ & 0.056 & $<0.020$ & $<0.020$ & 0.026 & $<0.020$ & 0.023 & $<0.020$ & $<0.020$ & $<0.020$ & $<0.020$ & $<0.020$ & $<0.020$ \\
\hline Boron & 0.020 & $<0.020$ & $<0.020$ & $<0.040$ & $<0.040$ & 0.194 & $<0.040$ & $<0.040$ & $<0.040$ & $<0.040$ & $<0.040$ & $<0.040$ & $<0.040$ & $<0.040$ & $<0.040$ & $<0.040$ & 0.283 & 0.226 \\
\hline Barlum & 0.001 & $<0.001$ & $<0.001$ & $<0.002$ & $<0.002$ & $<0.002$ & 0.056 & 0.044 & 0.031 & 0.036 & 0.030 & 0.026 & 0.004 & 0.004 & 0.003 & 0.022 & 0.028 & 0.028 \\
\hline Beryl & $<0.001$ & $<0.001$ & $<0.001$ & $<0.001$ & $<0.001$ & $<0.001$ & $<0.001$ & $<0.001$ & $<0.001$ & $<0.001$ & $<0.001$ & $<0.001$ & $<0.001$ & $<0.001$ & $<0.001$ & $<0.001$ & $<0.001$ & $<0.001$ \\
\hline Calc & $<0.040$ & $<0.040$ & $<0$ & $<0.080$ & 0.105 & 0.136 & 927 & 1373 & 1107 & 2627 & 2146 & 1848 & 4.591 & 5.07 & 3.765 & 11.24 & 12.60 & 14.35 \\
\hline Cadr & $<0.001$ & .001 & $<0$ & $<0.002$ & $<0.002$ & $<0.002$ & 0.004 & $<0.002$ & $<0.002$ & $<0.002$ & $<0.002$ & $<0.002$ & $<0.002$ & $<0.002$ & $<0.002$ & $<0.002$ & $<0.002$ & $<0.002$ \\
\hline Chre & $<0.005$ & $<0.005$ & $<0$ & $<0.010$ & $<0.010$ & $<0.010$ & 0.027 & $<0.010$ & $<0.010$ & $<0.010$ & $<0.010$ & $<0.010$ & $<0.010$ & $<0.010$ & $<0.010$ & $<0.010$ & $<0.010$ & $<0.010$ \\
\hline Copper & $<0.004$ & 0.004 & $<0$ & 3.622 & 3.229 & 4.210 & $<0.008$ & $<0.008$ & $<0.008$ & $<0.008$ & $<0.008$ & $<0.008$ & $<0.008$ & $<0.008$ & $<0.008$ & $<0.008$ & $<0.008$ & $<0.008$ \\
\hline Iron & $<0.050$ & $<0.050$ & $<0.050$ & $<0.100$ & $<0.100$ & $<0.100$ & 6.093 & 5.440 & 6.204 & $<0.100$ & $<0.100$ & $<0.100$ & 0.142 & 0.126 & $<0.100$ & $<0.100$ & $<0.100$ & 0.122 \\
\hline Potas & 5.476 & 2.961 & 4.771 & 2.602 & 6.235 & 2.500 & 6.631 & 8.300 & 7.56 & 4.487 & 5.338 & 3.888 & 3.542 & 2.87 & 2.73 & 3.028 & 5.064 & 4.62 \\
\hline Magr & $<0.020$ & $<0.020$ & $<0.020$ & $<0.040$ & $<0.040$ & $<0.040$ & 2.280 & 20.16 & 2.204 & 0.660 & 1.853 & 1.23 & 499 & 466 & 449 & 400 & 424 & 747 \\
\hline nese & 0.001 & $<0.001$ & .001 & 0.002 & $<0.002$ & $<0.002$ & 0.122 & 0.243 & 0.135 & $<0.002$ & $<0.002$ & $<0.002$ & $<0.002$ & $<0.002$ & 0.003 & $<0.002$ & $<0.002$ & $<0.002$ \\
\hline Sodlu & 1072 & 1003 & 1003 & 1413 & 1435 & 1428 & 1297 & 1318 & 1318 & 1337 & 1327 & 1284 & 1458 & 1483 & 1451 & 1536 & 1609 & 1673 \\
\hline Nickel & $<0.004$ & $<0.004$ & $<0.004$ & $<0.008$ & $<0.008$ & $<0.008$ & 0.031 & 0.026 & 0.020 & $<0.008$ & $<0.008$ & $<0.008$ & $<0.008$ & $<0.008$ & $<0.008$ & $<0.008$ & $<0.008$ & $<0.008$ \\
\hline Lead & $<0.007$ & $<0.007$ & $<0$. & $<0.014$ & $<0.014$ & $<0.014$ & $<0.014$ & $<0.014$ & $<0.014$ & $<0.014$ & $<0.014$ & $<0.014$ & $<0.014$ & $<0.014$ & $<0.014$ & $<0.014$ & $<0.014$ & $<0.014$ \\
\hline Selen & $<0.010$ & $<0.010$ & $<0.010$ & $<0.020$ & $<0.020$ & $<0.020$ & $<0.020$ & $<0.020$ & $<0.020$ & $<0.020$ & $<0.020$ & $<0.020$ & $<0.020$ & $<0.020$ & $<0.020$ & $<0.020$ & $<0.020$ & $<0.020$ \\
\hline Anlimony & $<0.010$ & $<0.010$ & $<0.010$ & $<0.020$ & $<0.020$ & $<0.020$ & 0.055 & $<0.020$ & $<0.020$ & $<0.020$ & $<0.020$ & $<0.020$ & $<0.020$ & $<0.020$ & $<0.020$ & $<0.020$ & $<0.020$ & $<0.020$ \\
\hline Sillicon & 0.504 & 0.053 & 0.043 & 0.610 & 1.804 & 3.528 & 23.70 & 29.71 & 25.21 & 8.536 & 6.992 & 5.731 & 0.427 & 0.410 & 0.431 & 0.159 & 0.103 & 0.763 \\
\hline Strontlum & $<0.001$ & $<0.001$ & $<0.001$ & $<0.002$ & $<0.002$ & $<0.002$ & 1.013 & 0.576 & 0.439 & 1.166 & 0.889 & 0.683 & 0.014 & 0.015 & 0.010 & 0.045 & 0.052 & 0.057 \\
\hline Thorlum & $<0.130$ & $<0.130$ & $<0.130$ & $<0.260$ & $<0.260$ & $<0.260$ & 4.157 & $<0.260$ & $<0.260$ & 0.314 & 0.269 & $<0.260$ & $<0.260$ & $<0.260$ & $<0.260$ & $<0.260$ & $<0.260$ & $<0.260$ \\
\hline Tilan & $<0.001$ & $<0.001$ & $<0.001$ & $<0.002$ & $<0.002$ & $<0.002$ & $<0.002$ & $<0.002$ & $<0.002$ & $<0.002$ & $<0.002$ & $<0.002$ & $<0.002$ & $<0.002$ & $<0.002$ & $<0.002$ & $<0.002$ & $<0.002$ \\
\hline llum & $<0.008$ & $<0.008$ & $<0.008$ & $<0.016$ & $<0.016$ & $<0.016$ & 0.059 & $<0.016$ & 0.016 & $<0.016$ & $<0.016$ & $<0.016$ & $<0.016$ & $<0.016$ & $<0.016$ & $<0.016$ & $<0.016$ & $<0.016$ \\
\hline & $<0.050$ & $<0.050$ & $<0.050$ & $<0.100$ & $<0.100$ & $<0.100$ & 1.504 & 0.106 & $<0.100$ & 0.304 & 0.285 & 0.274 & $<0.100$ & $<0.100$ & $<0.100$ & $<0.100$ & $<0.100$ & $<0.100$ \\
\hline Vanadlum & $<0.010$ & $<0.010$ & $<0.010$ & $<0.020$ & $<0.020$ & $<0.020$ & 0.120 & $<0.020$ & $<0.020$ & $<0.020$ & $<0.020$ & $<0.020$ & $<0.020$ & $<0.020$ & $<0.020$ & $<0.020$ & $<0.020$ & $<0.020$ \\
\hline Zinc & 0.008 & $<0.005$ & 0.008 & 0.020 & 0.014 & 0.034 & 35.08 & 73.91 & 0.242 & $<0.010$ & 0.013 & $<0.010$ & 0.44 & 38.90 & 60.91 & 45.71 & 0.16 & 63.34 \\
\hline Zirconium & 0.015 & 0.019 & 0.010 & $<0.020$ & $<0.020$ & $<0.020$ & $<0.020$ & $<0.020$ & $<0.020$ & $<0.020$ & $<0.020$ & $<0.020$ & $<0.020$ & $<0.020$ & $<0.020$ & 0.038 & 0.034 & 0.044 \\
\hline Mercury & 0.225 & 0.126 & 0.139 & 12000 & 4865 & 6371 & 10.6 & 9.61 & 11.1 & 183 & 227 & 142 & 7.48 & 60.3 & 570 & 56.0 & 6.7 & 800 \\
\hline
\end{tabular}

${ }^{\text {a}}$ Results in micrograms per liter. 
Table A.15. Leaching results (milligrams per liter) obtained at 3 months - pH 7

\begin{tabular}{|c|c|c|c|c|c|c|c|c|c|c|c|c|c|c|c|c|c|c|}
\hline & Blk-C & Blk-B & Bik-A & HG-B & $H G-A$ & HG-C & Lanl-3 & 1 Lanl-35 & 5 Lanl-36 & 6 Fern-4: & 43 Fern-4 & 14 Fern-45 & 5 OR-43 & OR-44 & OR-45 & ID-25 & ID-25A & ID-29 \\
\hline $\begin{array}{l}\text { Welght(g) } \\
\text { Inilial pH }\end{array}$ & 7.55 & 7.55 & 8.06 & $\begin{array}{l}6.00 \\
7.55\end{array}$ & $\begin{array}{l}13.00 \\
7.55\end{array}$ & $\begin{array}{l}13.00 \\
7.55\end{array}$ & $\begin{array}{l}13.82 \\
8.06\end{array}$ & $\begin{array}{l}18.09 \\
8.06\end{array}$ & $\begin{array}{l}16.22 \\
8.06\end{array}$ & $\begin{array}{l}13.60 \\
8.06\end{array}$ & $\begin{array}{l}20.89 \\
8.06\end{array}$ & $\begin{array}{l}26.59 \\
8.06\end{array}$ & $\begin{array}{l}7.56 \\
8.06\end{array}$ & $\begin{array}{l}8.14 \\
8.06\end{array}$ & $\begin{array}{l}11.27 \\
8.06\end{array}$ & $\begin{array}{l}6.28 \\
8.06\end{array}$ & $\begin{array}{l}4.13 \\
8.06\end{array}$ & $\begin{array}{l}12.13 \\
8.06\end{array}$ \\
\hline FInal pH & 5.57 & 5.42 & 5.62 & 7.41 & 7.01 & 7.74 & 4.82 & 6.04 & 6.01 & 7.04 & 7.32 & 7.50 & 10.68 & 10.72 & 10.68 & 10.60 & 11.01 & 10.61 \\
\hline Silver & $<0.003$ & $<0.003$ & $<0.003$ & $<0.005$ & $<0.005$ & $<0.005$ & $<0.005$ & $<0.005$ & $<0.005$ & $<0.005$ & $<0.005$ & $<0.005$ & $\leq 0.005^{\prime}$ & $<0.005$ & $<0.005$ & $<0.005$ & $<0.005$ & $<0.005$ \\
\hline Aluminum & $<0.030$ & $<0.030$ & $<0.030$ & $<0.060$ & $<0.060$ & $<0.060$ & $<0.060$ & $<0.060$ & $<0.060$ & $<0.060$ & $<0.060$ & $<0.060$ & $<0.060$ & $<0.060$ & $<0.060$ & 0.118 & 0.099 & $<0.060$ \\
\hline Arsenic & $<0.010$ & $<0.010$ & $<0.010$ & $<0.020$ & $<0.020$ & $<0.020$ & $<0.020$ & $<0.020$ & $<0.020$ & $<0.020$ & $<0.020$ & 0.021 & $<0.020$ & $<0.020$ & $<0.020$ & $<0.020$ & $<0.020$ & $<0.020$ \\
\hline Boron & $<0.020$ & $<0.020$ & $<0.020$ & 0.224 & 0.205 & 0.248 & 0.128 & 0.148 & 0.141 & 0.154 & 0.173 & 0.206 & 0.276 & 0.301 & 0.297 & 1.901 & 0.788 & 0.995 \\
\hline Barlum & $<0.001$ & $<0.001$ & $<0.001$ & $<0.002$ & $<0.002$ & $<0.002$ & 0.023 & 0.030 & 0.026 & 0.020 & 0.032 & 0.039 & $<0.002$ & $<0.002$ & $<0.002$ & 0.020 & 0.017 & 0.014 \\
\hline Beryllium & $<0.001$ & 0.001 & $<0.001$ & $<0.001$ & $<0.001$ & $<0.001$ & $<0.001$ & $<0.001$ & $<0.001$ & $<0.001$ & $<0.001$ & $<0.001$ & $<0.001$ & $<0.001$ & $<0.001$ & $<0.001$ & $<0.001$ & $<0.001$ \\
\hline Calclum & $<0.040$ & $<0.040$ & 0.049 & $<0.080$ & $<0.080$ & $<0.080$ & 1.160 & 1583 & 1401 & 1369 & 2447 & 3087 & 1.280 & 0.795 & 1.314 & 4.399 & 2.386 & 5.751 \\
\hline Cadmlum & $<0.001$ & $<0.001$ & $<0.001$ & $<0.002$ & $<0.002$ & $<0.002$ & $<0.002$ & $<0.002$ & $<0.002$ & $<0.002$ & $<0.002$ & $<0.002$ & $<0.002$ & $<0.002$ & $<0.002$ & $<0.002$ & $<0.002$ & $<0.002$ \\
\hline Chromlum & $<0.005$ & $<0.005$ & $<0.005$ & $<0.010$ & $<0.010$ & $<0.010$ & $<0.010$ & $<0.010$ & $<0.010$ & $<0.010$ & $<0.010$ & $<0.010$ & $<0.010$ & $<0.010$ & $<0.010$ & $<0.010$ & $<0.010$ & $<0.010$ \\
\hline Copper & 0.015 & 0.124 & 0.138 & 0.762 & 0.916 & 0.626 & $<0.008$ & $<0.008$ & $<0.008$ & $<0.008$ & $<0.008$ & $<0.008$ & 0.010 & 0.009 & $<0.008$ & $<0.008$ & $<0.008$ & $<0.008$ \\
\hline Iron & $<0.050$ & $<0.050$ & $<0.050$ & $<0.100$ & $<0.100$ & $<0.100$ & $<0.100$ & $<0.100$ & $<0.100$ & $<0.100$ & $<0.100$ & $<0.100$ & $<0.100$ & $<0.100$ & $<0.100$ & $<0.100$ & $<0.100$ & $<0.100$ \\
\hline Potassium & 2.082 & 1.974 & 3.895 & 4.575 & 1.913 & 1.990 & 7.919 & 5.21 & 5.232 & 2.608 & 4.013 & 7.215 & 22.96 & 3.769 & 2.651 & 7.498 & 19.20 & 8.493 \\
\hline Magnesium & $<0.020$ & $<0.020$ & $<0.020$ & $<0.040$ & $<0.040$ & $<0.040$ & 1.090 & 1.528 & 1.333 & 0.434 & 0.654 & 0.774 & 18.37 & 8.80 & 14.47 & 17.06 & 3.58 & 29.06 \\
\hline Manganese & $<0.001$ & $<0.001$ & $<0.001$ & $<0.002$ & $<0.002$ & $<0.002$ & 0.011 & 0.012 & 0.010 & $<0.002$ & $<0.002$ & 0.003 & $<0.002$ & $<0.002$ & $<0.002$ & $<0.002$ & $<0.002$ & $<0.002$ \\
\hline Sodium & $<0.060$ & $<0.060$ & $<0.060$ & 0.159 & $<0.120$ & 0.537 & 8.009 & 10.53 & 9.424 & 24.82 & 39.50 & 47.79 & 144 & 168 & 209 & 833 & 547 & 1502 \\
\hline Nickel & $<0.004$ & $<0.004$ & $<0.004$ & $<0.008$ & $<0.008$ & $<0.008$ & $<0.008$ & $<0.008$ & $<0.008$ & $<0.008$ & $<0.008$ & $<0.008$ & $<0.008$ & $<0.008$ & $<0.008$ & $<0.008$ & $<0.008$ & $<0.008$ \\
\hline Lead & $<0.007$ & $<0.007$ & $<0.007$ & $<0.014$ & $<0.014$ & $<0.014$ & $<0.014$ & $<0.014$ & $<0.014$ & $<0.014$ & $<0.014$ & $<0.014$ & $<0.014$ & $<0.014$ & $<0.014$ & $<0.014$ & $<0.014$ & $<0.014$ \\
\hline Selenium & $<0.010$ & $<0.010$ & $<0.010$ & $<0.020$ & $<0.020$ & $<0.020$ & $<0.020$ & $<0.020$ & $<0.020$ & $<0.020$ & $<0.020$ & $<0.020$ & $<0.020$ & $<0.020$ & $<0.020$ & $<0.020$ & $<0.020$ & $<0.020$ \\
\hline Antimony & $<0.010$ & $<0.010$ & $<0.010$ & $<0.020$ & $<0.020$ & $<0.020$ & $<0.020$ & $<0.020$ & $<0.020$ & $<0.020$ & $<0.020$ & $<0.020$ & $<0.020$ & $<0.020$ & $<0.020$ & $<0.020$ & $<0.020$ & $<0.020$ \\
\hline Silicon & 0.358 & 0.337 & 0.441 & 0.747 & 0.617 & 0.664 & 18.51 & 28.73 & 23.95 & 5.407 & 8.091 & 10.21 & 0.358 & 0.094 & 0.528 & 0.929 & 0.527 & 0.481 \\
\hline Strontlum & $<0.001$ & $<0.001$ & $<0.001$ & $<0.002$ & $<0.002$ & $<0.002$ & 0.459 & 0.657 & 0.569 & 0.542 & 1.051 & 1.375 & 0.003 & 0.002 & 0.003 & 0.021 & 0.017 & 0.042 \\
\hline Thorium & $<0.130$ & $<0.130$ & $<0.130$ & $<0.260$ & $<0.260$ & $<0.260$ & $<0.260$ & $<0.260$ & $<0.260$ & 0.350 & 0.302 & 0.494 & $<0.260$ & $<0.260$ & $<0.260$ & $<0.260$ & $<0.260$ & $<0.260$ \\
\hline Tilanium & $<0.001$ & $<0.001$ & $<0.001$ & $<0.002$ & $<0.002$ & $<0.002$ & $<0.002$ & $<0.002$ & $<0.002$ & $<0.002$ & $<0.002$ & $<0.002$ & $<0.002$ & $<0.002$ & $<0.002$ & $<0.002$ & $<0.002$ & $<0.002$ \\
\hline Thallium & $<0.008$ & $<0.008$ & $<0.008$ & $<0.016$ & $<0.016$ & $<0.016$ & 0.024 & $<0.016$ & $<0.016$ & 0.016 & $<0.016$ & 0.018 & $<0.016$ & $<0.016$ & $<0.016$ & $<0.016$ & $<0.016$ & $<0.016$ \\
\hline Uranlum & 0.072 & $<0.050$ & $<0.050$ & $<0.100$ & $<0.100$ & $<0.100$ & 0.186 & 0.125 & 0.157 & 0.256 & 0.279 & 0.372 & $<0.100$ & $<0.100$ & $<0.100$ & $<0.100$ & $<0.100$ & $<0.100$ \\
\hline Vanadlum & $<0.010$ & $<0.010$ & $<0.010$ & $<0.020$ & $<0.020$ & $<0.020$ & $<0.020$ & 0.024 & $<0.020$ & $<0.020$ & $<0.020$ & $<0.020$ & $<0.020$ & $<0.020$ & $<0.020$ & 0.021 & 0.038 & $<0.020$ \\
\hline Zinc & $<0.005$ & $<0.005$ & 0.018 & 0.013 & 0.021 & 0.016 & 0.018 & 0.062 & 0.070 & 0.012 & 0.018 & 0.012 & 0.145 & 0.153 & 0.116 & 0.117 & 0.129 & 0.076 \\
\hline Zirconium & $<0.010$ & 0.011 & 0.011 & $<0.020$ & $<0.020$ & $<0.020$ & $<0.020$ & $<0.020$ & $<0.020$ & $<0.020$ & $<0.020$ & $<0.020$ & $<0.020$ & $<0.020$ & $<0.020$ & 0.080 & 0.032 & 0.062 \\
\hline Mercury & 0.124 & 0.343 & 0.110 & 2904 & 2981 & 5114 & 17.9 & 26.3 & 18.8 & 1.4 & 36.9 & 285 & 10.4 & 7.4 & 3.95 & 8.99 & 10.70 & 8.46 \\
\hline
\end{tabular}

${ }^{a}$ Results in micrograms per liter. 
Table A.16. Leaching results (milligrams per liter) obtained at 3 months - pH 12.5

\begin{tabular}{|c|c|c|c|c|c|c|c|c|c|c|c|c|c|c|c|c|c|c|}
\hline & Blk-J & Blk-L & Blk-K & HG-20 & HG-15 & HG-16 & Lanl-13 & Lanl-14 & Lanl-15 & Fern-2 & 22 Fern-2 & 23 Forn-24 & OR-31 & OR-32 & OR-33 & ID-16 & ID-16A & $10-20$ \\
\hline $\begin{array}{l}\text { Welght(g) } \\
\text { Initlal pH }\end{array}$ & 12.68 & 12.48 & 12.48 & $\begin{array}{l}6.37 \\
12.68\end{array}$ & $\begin{array}{l}7.40 \\
12.68\end{array}$ & $\begin{array}{l}4.81 \\
12.68\end{array}$ & $\begin{array}{l}19.71 \\
12.48\end{array}$ & $\begin{array}{l}12.53 \\
12.48\end{array}$ & $\begin{array}{l}14.74 \\
12.48\end{array}$ & $\begin{array}{l}21.64 \\
12.48\end{array}$ & $\begin{array}{l}17.61 \\
12.48\end{array}$ & $\begin{array}{l}15.59 \\
12.48\end{array}$ & $\begin{array}{l}10.56 \\
12.48\end{array}$ & $\begin{array}{l}12.30 \\
12.48\end{array}$ & $\begin{array}{l}13.94 \\
12.48\end{array}$ & $\begin{array}{l}5.75 \\
12.68\end{array}$ & $\begin{array}{l}6.59 \\
12.68\end{array}$ & $\begin{array}{l}4.92 \\
12.48\end{array}$ \\
\hline Final pH & 12.72 & 12.70 & 12.71 & 12.77 & 12.81 & 12.80 & 8.75 & 10.82 & 9.19 & 9.62 & 8.95 & 9.13 & 12.06 & 12.08 & 11.94 & 12.56 & 12.63 & 12.74 \\
\hline Sllver & $<0.003$ & $<0.003$ & $<0.003$ & $<0.005$ & $<0.005$ & $<0.005$ & 0.008 & $<0.005$ & $<0.005$ & $<0.005$ & $<0.005$ & $<0.005$ & 0.009 & $<0.005$ & $<0.005$ & $<0.005$ & $<0.005$ & $<0.005$ \\
\hline Aluminum & $<0.030$ & $<0.030$ & $<0.030$ & $<0.060$ & $<0.060$ & $<0.060$ & $<0.060$ & $<0.060$ & $<0.060$ & $<0.060$ & $<0.060$ & $<0.060$ & $<0.060$ & $<0.060$ & $<0.060$ & $<0.060$ & $<0.060$ & $<0.060$ \\
\hline Arsenic & $<0.010$ & $<0.010$ & $<0.010$ & $<0.020$ & $<0.020$ & $<0.020$ & 0.028 & $<0.020$ & $<0.020$ & 0.033 & 0.023 & 0.025 & $<0.020$ & $<0.020$ & $<0.020$ & $<0.020$ & $<0.020$ & $<0.020$ \\
\hline Boron & $<0.020^{\circ}$ & $<0.020$ & $<0.020$ & 0.188 & 0.198 & 0.188 & 0.148 & 0.127 & 0.116 & 0.207 & 0.208 & 0.196 & 0.410 & 0.472 & 0.522 & 1.754 & 1.526 & 1.398 \\
\hline Barium & 0.012 & 0.015 & 0.016 & 0.013 & 0.011 & 0.012 & 0.117 & 0.079 & 0.093 & 0.052 & 0.049 & 0.040 & 0.015 & 0.014 & 0.016 & 0.050 & 0.054 & 0.058 \\
\hline Berylllum & $<0.001$ & $<0.001$ & $<0.001$ & $<0.001$ & $<0.001$ & $<0.001$ & 0.005 & $<0.001$ & $<0.001$ & $<0.001$ & $<0.001$ & $<0.001$ & $<0.001$ & $<0.001$ & $<0.001$ & $<0.001$ & $<0.001$ & $<0.001$ \\
\hline Calcium & 1226 & 1189 & 1225 & 1033 & 943 & 934 & 2436 & 1696 & 1967 & 4738 & 4098 & 3820 & 455 & 606 & 623 & 867 & 1023 & 1255 \\
\hline Cadmium & $<0.001$ & $<0.001$ & $<0.001$ & $<0.002$ & $<0.002$ & $<0.002$ & 0.004 & $<0.0$ & $<0.002$ & $<0.002$ & $<0.002$ & $<0.002$ & $<0.002$ & $<0.002$ & $<0.002$ & $<0.002$ & $<0.002$ & $<0.002$ \\
\hline Chromium & 0.018 & 0.024 & 0.028 & 0.019 & 0.014 & 0.017 & $<0.010$ & $<0.010$ & $<0.010$ & $<0.010$ & $<0.010$ & $<0.010$ & $<0.010$ & $<0.010$ & $<0.010$ & $<0.010$ & $<0.010$ & $<0.010$ \\
\hline Copper & $<0.004$ & $<0.004$ & $<0.004$ & 0.172 & 0.237 & 0.094 & $<0.008$ & $<0.008$ & $<0.008$ & $<0.008$ & $<0.008$ & $<0.008$ & $<0.008$ & $<0.008$ & $<0.008$ & $<0.008$ & $<0.008$ & $<0.008$ \\
\hline Iron & $<0.050$ & $<0.050$ & $<0.050$ & $<0.100$ & $<0.100$ & $<0.100$ & $<0.100$ & $<0.100$ & $<0.100$ & $<0.100$ & $<0.100$ & $<0.100$ & $<0.100$ & $<0.100$ & $<0.100$ & $<0.100$ & $<0.100$ & $<0.100$ \\
\hline Potasslum & 10.25 & 5.162 & 3.585 & 3.593 & 2.525 & 2.723 & 8.836 & 6.558 & 6.979 & 6.319 & 12.86 & 4.017 & 2.63 & 3.834 & 7.190 & 4.613 & 5.087 & 3.460 \\
\hline Magnesium & $<0.020$ & $<0.020$ & $<0.020$ & $<0.040$ & $<0.040$ & $<0.040$ & 1.041 & 0.099 & 0.423 & 0.794 & 0.943 & 0.695 & 0.064 & 0.052 & 0.122 & $<0.040$ & $<0.040$ & 0.244 \\
\hline Manganese & $<0.001$ & $<0.001$ & $<0.001$ & $<0.002$ & $<0.002$ & $<0.002$ & 0.006 & $<0.002$ & $<0.002$ & $<0.002$ & $<0.002$ & $<0.002$ & $<0.002$ & $<0.002$ & $<0.002$ & $<0.002$ & $<0.002$ & $<0.002$ \\
\hline Sodlum & 0.345 & 0.364 & 0.384 & 0.430 & 0.408 & 0.406 & 14.72 & 8.582 & 10.15 & 42.15 & 36.04 & 30.35 & 196 & 240 & 261 & 645 & 576 & 585 \\
\hline Nickel & $<0.004$ & $<0.004$ & $<0.004$ & $<0.008$ & $<0.008$ & $<0.008$ & 0.017 & $<0.008$ & $<0.008$ & $<0.008$ & $<0.008$ & $<0.008$ & $<0.008$ & $<0.008$ & $<0.008$ & $<0.008$ & $<0.008$ & $<0.008$ \\
\hline Lead & $<0.007$ & $<0.007$ & $<0.007$ & $<0.014$ & $<0.014$ & $<0.014$ & $<0.014$ & $<0.014$ & $<0.014$ & $<0.014$ & $<0.014$ & $<0.014$ & $<0.014$ & $<0.014$ & $<0.014$ & $<0.014$ & $<0.014$ & $<0.014$ \\
\hline Selenium & $<0.010$ & $<0.010$ & $<0.010$ & $<0.020$ & $<0.020$ & $<0.020$ & $<0.020$ & $<0.020$ & $<0.020$ & $<0.020$ & $<0.020$ & $<0.020$ & $<0.020$ & $<0.020$ & $<0.020$ & $<0.020$ & $<0.020$ & $<0.020$ \\
\hline Antimony & $<0.010$ & $<0.010$ & $<0.010$ & $<0.020$ & $<0.020$ & $<0.020$ & $<0.020$ & $<0.020$ & $<0.020$ & $<0.020$ & $<0.020$ & $<0.020$ & $<0.020$ & $<0.020$ & $<0.020$ & $<0.020$ & $<0.020$ & $<0.020$ \\
\hline Sillicon & 0.632 & 0.095 & 0.114 & 0.874 & 0.863 & 0.599 & 34.85 & 4.292 & 22.41 & 4.301 & 6.955 & 4.633 & 0.507 & 0.538 & 0.701 & 0.553 & 1.038 & 0.603 \\
\hline Strontlum & 0.604 & 0.713 & 0.744 & 0.685 & 0.590 & 0.607 & 1.708 & 1.269 & 1.415 & 2.497 & 2.181 & 2.001 & 0.716 & 0.722 & 0.790 & 0.564 & 0.624 & 0.777 \\
\hline Thorlum & $<0.130$ & $<0.130$ & 0.256 & 0.272 & $<0.260$ & $<0.260$ & $<0.260$ & $<0.260$ & 0.298 & 0.791 & 0.508 & 0.588 & $<0.260$ & $<0.260$ & $<0.260$ & $<0.260$ & $<0.260$ & $<0.260$ \\
\hline Titanium & $<0.001$ & $<0.001$ & 0.002 & $<0.002$ & $<0.002$ & $<0.002$ & $<0.002$ & $<0.002$ & $<0.002$ & $<0.002$ & $<0.002$ & $<0.002$ & $<0.002$ & $<0.002$ & $<0.002$ & $<0.002$ & $<0.002$ & $<0.002$ \\
\hline Thallum & $<0.008$ & $<0.008$ & $<0.008$ & $<0.016$ & $<0.016$ & $<0.016$ & 0.032 & $<0.016$ & 0.021 & $<0.016$ & 0.043 & 0.026 & $<0.016$ & $<0.016$ & $<0.016$ & $<0.016$ & $<0.016$ & $<0.016$ \\
\hline Uranium & 0.116 & 0.098 & 0.226 & 0.171 & 0.127 & 0.143 & 0.249 & 0.145 & 0.259 & 0.546 & 0.453 & 0.463 & $<0.100$ & 0.120 & 0.117 & $<0.100$ & $<0.100$ & $<0.100$ \\
\hline Vanadlum & $<0.010$ & $<0.010$ & $<0.010$ & $<0.020$ & $<0.020$ & $<0.020$ & 0.036 & $<0.020$ & $<0.020$ & $<0.020$ & $<0.020$ & $<0.020$ & $<0.020$ & $<0.020$ & $<0.020$ & $<0.020$ & $<0.020$ & 0.021 \\
\hline Zinc & $<0.005$ & $<0.005$ & 0.010 & 0.016 & 0.012 & 0.019 & 0.200 & 0.042 & 0.021 & $<0.010$ & $<0.010$ & $<0.010$ & 0.946 & 1.044 & 0.918 & 1.931 & 2.299 & 2.566 \\
\hline Zirconium & $<0.010$ & $<0.010$ & $<0.010$ & $<0.020$ & $<0.020$ & $<0.020$ & $<0.020$ & $<0.020$ & $<0.020$ & $<0.020$ & $<0.020$ & $<0.020$ & $<0.020$ & $<0.020$ & $<0.020$ & $<0.020$ & $<0.020$ & 0.024 \\
\hline Mercury & 0.179 & 0.137 & 0.131 & 11192 & ? 12057 & 10528 & 12.50 & 11.20 & 11.00 & 663 & 20.2 & 108 & 17.2 & 27.8 & 27.5 & 80.0 & 34.0 & 217.0 \\
\hline
\end{tabular}

${ }^{a}$ Results in micrograms per liter. 


\section{APPENDLX B}

\section{LEACEING RESULTS SORTED BY SAMPLE TYPE}



Table B.1. Leaching results (milligrams per liter) for the blank series

\begin{tabular}{|c|c|c|c|c|c|c|c|c|c|c|c|c|c|c|c|c|c|}
\hline \multirow[b]{2}{*}{ Time } & \multicolumn{4}{|c|}{$\mathrm{pH} 3$} & \multicolumn{4}{|c|}{$\mathrm{pH} 5$} & \multicolumn{5}{|c|}{$\mathrm{pH} 7$} & \multicolumn{4}{|c|}{ pH 12.5} \\
\hline & $2 w$ & $1 \mathrm{~m}$ & $2 m$ & $3 m$ & $2 w$ & $1 \mathrm{~m}$ & $2 m$ & $3 m$ & $2 w$ & & $1 \mathrm{~m}$ & $2 m$ & $3 m$ & $2 w$ & $1 \mathrm{~m}$ & $2 m$ & $3 m$ \\
\hline Initial pH & 2.96 & 2.96 & 2.98 & 2.98 & 5.00 & 4.63 & 4.80 & 4.80 & 7.87 & & 7.55 & 7.72 & 7.72 & 12.53 & 12.53 & 12.55 & 12.55 \\
\hline Final pH & 2.87 & 2.88 & 2.85 & 2.82 & 5.06 & 4.65 & 4.92 & 4.82 & 6.86 & & 5.63 & 6.44 & 5.54 & 12.77 & 12.72 & 12.74 & 12.71 \\
\hline Silver & $<0.003$ & $<0.003$ & $<0.003$ & $<0.003$ & $<0.003$ & $<0.003$ & $<0.003$ & $<0.003$ & $<0.003$ & $<$ & 0.003 & $<0.003$ & $<0.003$ & $<0.003$ & $<0.003$ & $<0.003$ & $<0.003$ \\
\hline Aluminum & 0.076 & 0.039 & 0.060 & $<0.030$ & $<0.030$ & $<0.030$ & $<0.030$ & $<0.030$ & 0.073 & & 0.048 & 0.075 & $<0.030$ & 0.078 & 0.050 & 0.089 & $<0.030$ \\
\hline Arsenic & $<0.010$ & $<0.010$ & $<0.010$ & $<0.010$ & $<0.010$ & $<0.010$ & $<0.010$ & $<0.010$ & $<0.010$ & $<$ & 0.010 & $<0.010$ & $<0.010$ & $<0.010$ & $<0.010$ & 0.012 & $<0.010$ \\
\hline Boron & $<0.020$ & $<0.020$ & $<0.020$ & $<0.020$ & $<0.020$ & $<0.020$ & $<0.020$ & $<0.020$ & $<0.020$ & $<$ & 0.020 & $<0.020$ & $<0.020$ & $<0.020$ & $<0.020$ & $<0.020$ & $<0.020$ \\
\hline Barlum & $<0.001$ & $<0.001$ & $<0.001$ & $<0.001$ & 0.001 & $<0.001$ & $<0.001$ & $<0.001$ & $<0.001$ & $<$ & 0.001 & $<0.001$ & $<0.001$ & 0.016 & 0.012 & 0.015 & 0.014 \\
\hline Beryllium & 0.002 & 0.001 & 0.002 & $<0.001$ & 0.002 & 0.001 & 0.002 & $<0.001$ & 0.002 & & 0.001 & 0.002 & 0.001 & 0.002 & 0.001 & 0.002 & $<0.001$ \\
\hline Calclum & 0.040 & 0.044 & 0.083 & $<0.040$ & $<0.040$ & $<0.040$ & 0.054 & $<0.040$ & 0.193 & & 0.202 & $<0.040$ & 0.043 & 1025 & 1182 & 973 & 1213 \\
\hline Cadmlum & $<0.001$ & $<0.001$ & $<0.001$ & $<0.001$ & $<0.001$ & $<0.001$ & $<0.001$ & $<0.001$ & $<0.001$ & $<$ & 0.001 & $<0.001$ & $<0.001$ & $<0.001$ & $<0.001$ & $<0.001$ & $<0.001$ \\
\hline Chromium & $<0.005$ & $<0.005$ & $<0.005$ & $<0.005$ & $<0.005$ & $<0.005$ & $<0.005$ & $<0.005$ & $<0.005$ & $<$ & 0.005 & $<0.005$ & $<0.005$ & 0.031 & 0.013 & 0.021 & 0.023 \\
\hline Copper & $<0.004$ & 0.004 & $<0.004$ & 0.004 & $<0.004$ & $<0.004$ & $<0.004$ & $<0.004$ & 0.008 & & 0.004 & $<0.004$ & 0.092 & $<0.004$ & 0.011 & 0.014 & $<0.004$ \\
\hline Iron & $<0.050$ & $<0.050$ & $<0.050$ & $<0.050$ & $<0.050$ & $<0.050$ & $<0.050$ & $<0.050$ & $<0.050$ & $<$ & 0.050 & $<0.050$ & $<0.050$ & $<0.050$ & $<0.050$ & $<0.050$ & $<0.050$ \\
\hline Polassium & 6.94 & 0.631 & 5.17 & 2.88 & 5.47 & 1.11 & 5.66 & 4.40 & 4.12 & & 1.10 & 5.29 & 2.65 & 11.49 & 0.54 & 8.48 & 6.33 \\
\hline Magnesium & $<0.020$ & $<0.020$ & $<0.020$ & $<0.020$ & $<0.020$ & $<0.020$ & $<0.020$ & $<0.020$ & $<0.020$ & & 0.023 & $<0.020$ & $<0.020$ & $<0.020$ & $<0.022$ & $<0.020$ & $<0.020$ \\
\hline Manganese & $<0.001$ & $<0.001$ & $<0.001$ & $<0.001$ & $<0.001$ & $<0.001$ & $<0.001$ & $<0.001$ & $<0.001$ & $<$ & 0.001 & $<0.001$ & $<0.001$ & $<0.001$ & $<0.001$ & $<0.001$ & $<0.001$ \\
\hline Sodlum & 0.282 & 0.069 & 0.068 & 0.537 & 1235 & 1183 & 1156 & 1026 & 0.063 & & 0.088 & $<0.060$ & $<0.060$ & 0.938 & 0.553 & 0.743 & 0.364 \\
\hline Nickel & $<0.004$ & $<0.004$ & $<0.004$ & $<0.004$ & $<0.004$ & $<0.004$ & $<0.004$ & $<0.004$ & $<0.004$ & $<$ & 0.004 & $<0.004$ & $<0.004$ & $<0.004$ & $<0.004$ & $<0.004$ & $<0.004$ \\
\hline Lead & $<0.007$ & $<0.007$ & $<0.007$ & $<0.007$ & $<0.007$ & $<0.007$ & $<0.007$ & $<0.007$ & $<0.007$ & $<$ & 0.007 & $<0.007$ & $<0.007$ & $<0.007$ & $<0.007$ & $<0.007$ & $<0.007$ \\
\hline Selenlum & 0.021 & 0.015 & 0.027 & 0.010 & $<0.010$ & $<0.010$ & $<0.010$ & $<0.010$ & $<0.011$ & $<$ & 0.010 & 0.018 & $<0.010$ & $<0.010$ & $<0.010$ & 0.010 & $<0.010$ \\
\hline Antimony & $<0.010$ & $<0.010$ & $<0.010$ & $<0.010$ & $<0.010$ & $<0.010$ & $<0.010$ & $<0.010$ & $<0.010$ & $<$ & 0.010 & $<0.010$ & $<0.010$ & $<0.010$ & $<0.010$ & $<0.010$ & $<0.010$ \\
\hline Sillicon & 0.534 & 0.589 & 0.546 & 0.318 & 0.553 & 0.567 & 0.518 & 0.200 & 0.461 & & 0.493 & 0.491 & 0.379 & 1.121 & 0.693 & 0.761 & 0.280 \\
\hline Strontlum & $<0.001$ & $<0.001$ & $<0.001$ & $<0.001$ & $<0.001$ & $<0.001$ & $<0.001$ & $<0.001$ & $<0.001$ & $<$ & 0.001 & $<0.001$ & $<0.001$ & 0.868 & 0.727 & 0.811 & 0.687 \\
\hline Thorlum & $<0.130$ & $<0.130$ & $<0.130$ & $<0.130$ & $<0.130$ & $<0.130$ & $<0.130$ & $<0.130$ & $<0.130$ & $<$ & 0.130 & $<0.130$ & $<0.130$ & $<0.130$ & $<0.130$ & $<0.130$ & 0.172 \\
\hline Titanlum & 0.001 & $<0.001$ & $<0.001$ & $<0.001$ & 0.001 & $<0.001$ & $<0.001$ & $<0.001$ & 0.001 & $<$ & 0.001 & $<0.001$ & $<0.001$ & 0.006 & 0.005 & 0.005 & 0.001 \\
\hline Thalilum & $<0.008$ & $<0.008$ & $<0.008$ & $<0.008$ & $<0.008$ & $<0.008$ & $<0.008$ & $<0.008$ & $<0.008$ & $<$ & 0.008 & $<0.008$ & $<0.008$ & $<0.008$ & $<0.008$ & $<0.008$ & $<0.008$ \\
\hline Uranlum & 0.079 & 0.053 & $<0.051$ & 0.064 & 0.063 & 0.062 & 0.051 & $<0.050$ & 0.075 & & 0.055 & 0.055 & 0.057 & 0.085 & 0.060 & 0.057 & 0.147 \\
\hline Vanadlum & $<0.010$ & $<0.010$ & $<0.010$ & $<0.010$ & $<0.010$ & $<0.010$ & $<0.010$ & $<0.010$ & $<0.010$ & $<$ & 0.010 & $<0.010$ & $<0.010$ & $<0.010$ & 0.010 & $<0.010$ & $<0.010$ \\
\hline Zinc & 0.010 & 0.009 & 0.007 & 0.006 & 0.007 & 0.012 & 0.007 & 0.007 & 0.009 & & 0.010 & $<0.005$ & 0.009 & 0.005 & 0.008 & $<0.005$ & 0.007 \\
\hline Zlrconlum & $<0.010$ & $<0.010$ & $<0.010$ & $<0.010$ & 0.012 & 0.012 & $<0.010$ & 0.015 & $<0.010$ & $<$ & 0.010 & $<0.010$ & 0.011 & 0.010 & 0.010 & $<0.010$ & $<0.010$ \\
\hline Mercury & 0.153 & 0.070 & $<0.050$ & 0.232 & 0.119 & 0.459 & 0.107 & 0.163 & 0.092 & & 0.07 & $<0.050$ & 0.192 & 0.349 & 0.140 & 0.485 & 0.149 \\
\hline
\end{tabular}

${ }^{2}$ Results are in micrograms per liter. 
Table B.2. Leaching results (milligrams per liter) for the mercury standard series

\begin{tabular}{|c|c|c|c|c|c|c|c|c|c|c|c|c|c|c|c|c|c|c|}
\hline \multirow[b]{2}{*}{ Time } & \multicolumn{4}{|c|}{$\mathrm{pH} 3$} & \multicolumn{4}{|c|}{$\mathrm{pH} 5$} & \multicolumn{4}{|c|}{$\mathrm{pH} 7$} & \multicolumn{6}{|c|}{$\mathrm{pH} 12.5$} \\
\hline & $2 w$ & $1 \mathrm{~m}$ & $2 m$ & $3 m$ & $2 w$ & $1 \mathrm{~m}$ & $2 m$ & $3 m$ & $2 w$ & $1 \mathrm{~m}$ & $2 m$ & $3 m$ & $2 w$ & $1 \mathrm{~m}$ & & $2 m$ & & $3 m$ \\
\hline Welght(g) & 12.27 & 8.33 & 5.29 & 6.34 & 15.34 & 11.00 & 11.00 & 11.33 & 20.89 & 14.00 & 9.00 & 10.67 & & & & & & \\
\hline Inillal pH & 2.96 & 2.96 & 2.92 & 2.85 & 5.00 & 5.00 & 4.63 & 4.63 & 7.87 & 7.87 & 7.55 & 7.55 & 12.53 & 12.53 & & 12.68 & & 12.68 \\
\hline Final pH & 2.87 & 2.58 & 2.88 & 2.91 & 5.02 & 4.69 & 4.76 & 4.79 & 7.28 & 6.22 & 6.95 & 7.39 & 12.73 & 12.27 & & 12.73 & & 12.79 \\
\hline Silver & $<0.005$ & 0.007 & $<0.013$ & 0.005 & $<0.005$ & $<0.003$ & $<0.013$ & $<0.005$ & $<0.005$ & $<0.003$ & $<0.013$ & $<0.005$ & 0.011 & $<0.003$ & & 0.016 & $<$ & 0.005 \\
\hline Aluminum & 0.315 & 0.367 & 0.471 & 0.061 & 0.225 & 0.225 & 0.659 & 0.205 & 0.152 & 0.056 & 0.464 & $<0.060$ & 0.205 & 0.059 & & 0.495 & $<$ & 0.060 \\
\hline Arsenic & $<0.020$ & $<0.010$ & $<0.050$ & $<0.020$ & $<0.020$ & $<0.010$ & $<0.050$ & $<0.020$ & $<0.020$ & $<0.010$ & $<0.050$ & $<0.020$ & 0.020 & 0.010 & $<$ & 0.050 & $<$ & 0.020 \\
\hline Boron & $<0.040$ & $<0.020$ & $<0.100$ & $\cdot 1.169$ & $<0.040$ & $<0.020$ & $<0.100$ & 0.091 & $<0.040$ & $<0.020$ & $<0.100$ & 0.225 & $<0.040$ & $<0.020$ & $<$ & 0.100 & & 0.191 \\
\hline Barium & $<0.002$ & $<0.001$ & $<0.005$ & 0.002 & $<0.002$ & 0.001 & $<0.005$ & $<0.002$ & $<0.002$ & $<0.001$ & $<0.005$ & $<0.002$ & 0.021 & 0.014 & & 0.012 & & 0.012 \\
\hline Berylllum & 0.002 & 0.001 & 0.011 & $<0.001$ & 0.003 & 0.001 & 0.012 & $<0.001$ & 0.003 & 0.001 & 0.012 & $<0.001$ & 0.003 & 0.001 & & 0.012 & $<$ & 0.001 \\
\hline Calclum & 0.121 & $<0.041$ & 0.266 & 0.208 & 0.268 & 0.310 & 0.223 & 0.107 & $<0.080$ & 0.054 & $<0.200$ & $<0.080$ & 1326 & 1235 & & 970 & & 970 \\
\hline Cadmium & $<0.002$ & $<0.001$ & $<0.005$ & $<0.002$ & $<0.002$ & $<0.001$ & $<0.005$ & $<0.002$ & $<0.002$ & $<0.001$ & $<0.005$ & $<0.002$ & $<0.002$ & $<0.001$ & $<$ & 0.005 & $<$ & 0.002 \\
\hline Chromlum & $<0.010$ & $<0.005$ & $<0.025$ & $<0.010$ & $<0.010$ & $<0.005$ & $<0.025$ & $<0.010$ & $<0.010$ & $<0.005$ & $<0.025$ & $<0.010$ & 0.039 & 0.016 & $<$ & 0.025 & & 0.016 \\
\hline Copper & 3.07 & 2.71 & 1.15 & 1.53 & $\mathbf{3 . 7 8}$ & 3.33 & 3.61 & 3.69 & 0.450 & 0.709 & 0.552 & 0.768 & 0.800 & 0.380 & & 0.235 & & 0.168 \\
\hline Iron & $<0.100$ & $<0.050$ & $<0.250$ & $<0.100$ & $<0.100$ & $<0.050$ & $<0.250$ & $<0.100$ & $<0.100$ & $<0.050$ & $<0.250$ & $<0.100$ & $<0.100$ & $<0.050$ & $<$ & 0.250 & $<$ & 0.100 \\
\hline Potasslum & 3.59 & 3.04 & 4.59 & 1.73 & 6.11 & 1.52 & 7.18 & 3.78 & 4.75 & 1.10 & 7.63 & 2.83 & 7.15 & 1.13 & & 3.94 & & 2.95 \\
\hline Magnesium & $<0.040$ & $<0.020$ & $<0.100$ & $<0.040$ & $<0.040$ & $<0.020$ & $<0.100$ & $<0.040$ & $<0.040$ & $<0.020$ & $<0.100$ & $<0.040$ & $<0.040$ & $<0.020$ & $<$ & 0.100 & $<$ & 0.040 \\
\hline Manganese & $<0.002$ & $<0.001$ & $<0.006$ & $<0.002$ & $<0.002$ & $<0.001$ & $<0.006$ & $<0.002$ & $<0.002$ & $<0.001$ & $<0.006$ & $<0.002$ & $<0.002$ & $<0.001$ & $<$ & 0.006 & $<$ & 0.002 \\
\hline Sodlum & 0.213 & 0.406 & 0.301 & $<0.120$ & 1396 & 1210 & 1482 & 1425 & 0.232 & 0.096 & 0.414 & 0.272 & 1.336 & 0.624 & & 0.516 & & 0.415 \\
\hline Nickel & $<0.008$ & $<0.004$ & $<0.020$ & $<0.008$ & $<0.008$ & $<0.004$ & $<0.020$ & $<0.008$ & $<0.008$ & $<0.004$ & $<0.020$ & $<0.008$ & $<0.008$ & $<0.004$ & $<$ & 0.020 & $<$ & 0.008 \\
\hline Lead & $<0.014$ & $<0.007$ & $<0.035$ & $<0.014$ & $<0.014$ & $<0.007$ & $<0.035$ & $<0.014$ & $<0.014$ & $<0.007$ & $<0.035$ & $<0.014$ & $<0.014$ & $<0.007$ & $<$ & 0.035 & $<$ & 0.014 \\
\hline Selenlum & 0.036 & 0.018 & 0.092 & 0.023 & $<0.020$ & $<0.010$ & 0.052 & $<0.020$ & 0.024 & 0.011 & 0.073 & $<0.020$ & $<0.020$ & $<0.010$ & & 0.083 & $<$ & 0.020 \\
\hline Antimony & $<0.020$ & $<0.010$ & $<0.050$ & $<0.020$ & $<0.020$ & $<0.010$ & $<0.050$ & $<0.020$ & $<0.020$ & $<0.010$ & $<0.050$ & $<0.020$ & $<0.020$ & $<0.010$ & $<$ & 0.050 & $<$ & 0.020 \\
\hline Sillicon & 0.599 & 0.596 & 0.459 & 15.26 & 0.559 & 0.573 & 0.433 & 1.98 & 0.523 & 0.474 & 0.442 & 0.676 & 1.149 & 0.909 & & 0.686 & & 0.779 \\
\hline Strontlum & $<0.002$ & $<0.001$ & $<0.005$ & $<0.002$ & $\mid<0.002$ & $<0.001$ & $<0.005$ & $<0.002$ & $<0.002$ & $<0.001$ & $<0.005$ & $<0.002$ & 1.088 & 0.819 & & 0.499 & & 0.627 \\
\hline Thorium & $<0.260$ & $<0.130$ & $<0.650$ & 0.287 & $<0.260$ & $<0.130$ & $<0.650$ & $<0.260$ & $<0.260$ & $<0.130$ & $<0.650$ & $<0.260$ & $<0.260$ & $<0.130$ & $<$ & 0.650 & & 0.264 \\
\hline Titanlum & $<0.002$ & $<0.001$ & $<0.005$ & $<0.002$ & $<0.002$ & $<0.001$ & $<0.005$ & $<0.002$ & $<0.002$ & $<0.001$ & $<0.005$ & $<0.002$ & 0.007 & 0.005 & & 0.006 & $<$ & 0.002 \\
\hline Thalllum & $<0.016$ & $<0.008$ & $<0.040$ & $<0.016$ & $<0.016$ & $<0.008$ & $<0.040$ & $<0.016$ & $<0.016$ & $<0.008$ & $<0.040$ & $<0.016$ & $<0.016$ & $<0.008$ & $<$ & 0.040 & $<$ & 0.016 \\
\hline Uranlum & $<0.100$ & 0.075 & $<0.250$ & 0.113 & $<0.100$ & 0.059 & $<0.250$ & $<0.100$ & $<0.100$ & 0.063 & $<0.250$ & $<0.100$ & 0.101 & 0.069 & $<$ & 0.250 & & 0.147 \\
\hline Vanadium & $<0.020$ & $<0.010$ & $<0.050$ & $<0.020$ & $<0.020$ & $<0.010$ & $<0.050$ & $<0.020$ & $<0.020$ & $<0.010$ & $<0.050$ & $<0.020$ & $<0.020$ & $<0.010$ & $<$ & 0.050 & $<$ & 0.020 \\
\hline Zinc & 0.013 & 0.011 & $<0.025$ & 0.020 & 0.021 & 0.012 & $<0.025$ & 0.023 & $<0.010$ & 0.010 & $<0.025$ & 0.017 & 0.014 & 0.006 & $<$ & 0.025 & & 0.016 \\
\hline Zirconlum & $<0.020$ & $<0.010$ & $<0.050$ & $<0.020$ & $<0.020$ & 0.011 & $<0.050$ & $<0.020$ & $<0.020$ & $<0.010$ & $<0.050$ & $<0.020$ & $<0.020$ & $<0.010$ & $<$ & 0.050 & $<$ & 0.020 \\
\hline Mercury & 723 & 1337 & 537 & 4257 & 1368 & 3986 & 3111 & 7745 & 641 & 2739 & 1371 & 3666 & 5231 & 6594 & & 4534 & & 11259 \\
\hline
\end{tabular}

${ }^{2}$ Results are in micrograms per liter. 
Table B.3. Leaching results (milligrams per liter) for the LANL series

\begin{tabular}{|c|c|c|c|c|c|c|c|c|c|c|c|c|c|c|c|c|}
\hline \multirow[b]{2}{*}{ Time } & \multicolumn{4}{|c|}{$\mathrm{pH} 3$} & \multicolumn{4}{|c|}{$\mathrm{pH} 5$} & \multicolumn{4}{|c|}{$\mathrm{pH} 7$} & \multicolumn{4}{|c|}{$\mathrm{pH} 12.5$} \\
\hline & $2 w$ & $1 \mathrm{~m}$ & $2 m$ & $3 m$ & $2 w$ & $1 \mathrm{~m}$ & $2 m$ & $3 m$ & $2 w$ & $1 \mathrm{~m}$ & $2 m$ & $3 m$ & $2 w$ & $1 \mathrm{~m}$ & $2 \mathrm{~m}$ & $3 m$ \\
\hline Welght(g) & 7.97 & 12.18 & 13.79 & 14.79 & 11.76 & 11.03 & 12.72 & 12.10 & 8.28 & 11.56 & 19.29 & 16.04 & 9.08 & 9.09 & 13.34 & 15.66 \\
\hline Initlal pH & 2.96 & 2.85 & 3.05 & 3.05 & 5.00 & 4.63 & 4.89 & 4.89 & 7.87 & 7.55 & 8.06 & 8.06 & 12.53 & 12.68 & 12.48 & 12.48 \\
\hline Final pH & 3.37 & 3.33 & 3.76 & 3.83 & 5.06 & 4.61 & 5.06 & 5.20 & 5.83 & 6.08 & 7.07 & 5.62 & 12.60 & 12.20 & 10.66 & 9.59 \\
\hline Silver & $<0.005$ & $<0.013$ & $<0.013$ & $<0.005$ & $<0.005$ & $<0.013$ & $<0.013$ & 0.011 & $<0.005$ & $<0.013$ & $<0.013$ & $<0.005$ & $<0.005$ & 0.013 & $<0.013$ & 0.006 \\
\hline Aluminum & 2.00 & 4.58 & 6.92 & 6.65 & $<0.060$ & 0.647 & 0.757 & 0.161 & 0.126 & 0.207 & 0.371 & $<0.060$ & 0.132 & 0.236 & 0.543 & $<0.060$ \\
\hline Arsenic & $<0.020$ & $<0.050$ & $<0.050$ & $<0.020$ & $<0.020$ & $<0.050$ & $<0.050$ & 0.032 & $<0.020$ & $<0.050$ & $<0.050$ & $<0.020$ & $<0.020$ & $<0.050$ & $<0.050$ & 0.023 \\
\hline Boron & $<0.040$ & $<0.100$ & $<0.100$ & 0.153 & $<0.040$ & $<0.100$ & $<0.100$ & $<0.040$ & $<0.040$ & $<0.100$ & $<0.100$ & 0.139 & $<0.040$ & $<0.100$ & $<0.100$ & 0.130 \\
\hline Barlum & 0.011 & 0.029 & 0.039 & 0.035 & 0.021 & 0.029 & 0.035 & 0.044 & 0.012 & 0.023 & 0.034 & 0.026 & 0.037 & 0.062 & 0.087 & 0.096 \\
\hline Beryllium & 0.003 & 0.008 & 0.014 & $<0.001$ & 0.003 & 0.009 & 0.013 & $<0.001$ & 0.003 & 0.009 & 0.009 & $<0.001$ & 0.003 & 0.008 & 0.012 & 0.002 \\
\hline Calcium & 677 & 1063 & 1249 & 1334 & 977 & 986 & 1155 & 1136 & 645 & 926 & 1481 & 1382 & 1653 & 1637 & 1610 & 2033 \\
\hline Cadmium & $<0.002$ & $<0.005$ & $<0.005$ & $<0.002$ & $<0.002$ & $<0.005$ & $<0.005$ & 0.003 & $<0.002$ & $<0.005$ & $<0.005$ & $<0.002$ & $<0.002$ & $<0.005$ & $<0.005$ & 0.003 \\
\hline Chromium & 0.016 & 0.033 & 0.029 & 0.032 & $<0.010$ & $<0.025$ & $<0.025$ & 0.016 & $<0.010$ & $<0.025$ & $<0.025$ & $<0.010$ & 0.013 & $<0.025$ & $<0.025$ & $<0.010$ \\
\hline Copper & $<0.008$ & $<0.020$ & $<0.020$ & $<0.008$ & $<0.008$ & $<0.020$ & $<0.020$ & $<0.008$ & $<0.008$ & $<0.020$ & 0.022 & $<0.008$ & $<0.008$ & 0.040 & 0.037 & $<0.008$ \\
\hline Iron & 7.69 & 12.90 & 19.80 & 17.57 & 3.48 & 7.67 & 5.56 & 5.91 & $<0.100$ & $<0.250$ & $<0.250$ & $<0.100$ & $<0.100$ & $<0.250$ & $<0.250$ & $<0.100$ \\
\hline Potassium & 6.85 & 3.90 & 9.80 & 7.05 & 9.43 & 4.38 & 11.50 & 7.50 & 7.30 & 3.14 & 9.10 & 6.12 & 6.16 & 3.92 & 9.87 & 7.46 \\
\hline Magnesium & 1.36 & 2.53 & 3.22 & 3.89 & 1.46 & 2.08 & 2.49 & 8.22 & 0.57 & 0.82 & 1.356 & 1.32 & 0.042 & $<0.100$ & 0.112 & 0.521 \\
\hline Manganese & 0.087 & 0.139 & 0.295 & 0.363 & 0.089 & 0.142 & 0.144 & 0.167 & 0.004 & 0.007 & 0.087 & 0.011 & $<0.002$ & 0.007 & $<0.006$ & 0.004 \\
\hline Sodium & 4.71 & 7.99 & 10.22 & 9.79 & 1379 & 1515 & 1341 & 1311 & 4.50 & 7.22 & 12.12 & 9.32 & 6.06 & 7.08 & 9.38 & 11.15 \\
\hline Nickel & 0.017 & 0.023 & 0.027 & 0.034 & 0.015 & $<0.020$ & 0.021 & 0.025 & $<0.008$ & $<0.020$ & $<0.020$ & $<0.008$ & $<0.008$ & $<0.020$ & $<0.020$ & 0.011 \\
\hline Lead & $<0.014$ & $<0.035$ & $<0.035$ & $<0.014$ & $<0.014$ & $<0.035$ & $<0.035$ & $<0.014$ & $<0.014$ & $<0.035$ & $<0.035$ & $<0.014$ & $<0.014$ & $<0.035$ & $<0.035$ & $<0.014$ \\
\hline Selenium & $<0.020$ & $<0.050$ & 0.078 & $<0.020$ & $<0.020$ & $<0.050$ & $<0.050$ & $<0.020$ & $<0.020$ & $<0.050$ & 0.055 & $<0.020$ & $<0.020$ & $<0.050$ & 0.073 & $<0.020$ \\
\hline Antimony & $<0.020$ & $<0.050$ & $<0.050$ & $<0.020$ & $<0.020$ & $<0.050$ & $<0.050$ & 0.032 & $<0.020$ & $<0.050$ & $<0.050$ & $<0.020$ & $<0.020$ & $<0.050$ & $<0.050$ & $<0.020$ \\
\hline Sillcon & 4.78 & 17.16 & 29.04 & 34.33 & 10.54 & 16.84 & 23.26 & 26.20 & 8.78 & 14.81 & 22.04 & 23.73 & 1.16 & 1.45 & 4.59 & 20.52 \\
\hline Strontlum & 0.244 & 0.346 & 0.391 & 0.562 & 0.361 & 0.287 & 0.320 & 0.676 & 0.227 & 0.282 & 0.500 & 0.562 & 1.17 & 1.18 & 1.09 & 1.46 \\
\hline Thorium & $<0.260$ & $<0.650$ & $<0.650$ & $<0.260$ & $<0.260$ & $<0.650$ & $<0.650$ & 1.559 & $<0.260$ & $<0.650$ & $<0.650$ & $<0.260$ & $<0.260$ & $<0.650$ & $<0.650$ & 0.273 \\
\hline Titanium & 0.004 & 0.007 & 0.007 & $<0.002$ & 0.006 & 0.006 & 0.006 & $<0.002$ & 0.004 & 0.005 & 0.007 & $<0.002$ & 0.009 & 0.010 & 0.009 & $<0.002$ \\
\hline Thallium & $<0.016$ & $<0.040$ & $<0.040$ & 0.016 & $<0.016$ & $<0.040$ & $<0.040$ & 0.030 & $<0.016$ & $<0.040$ & $<0.040$ & 0.019 & $<0.016$ & $<0.040$ & $<0.040$ & 0.023 \\
\hline Uranlum & $<0.100$ & $<0.250$ & $<0.250$ & $<0.100$ & $<0.100$ & $<0.250$ & $<0.250$ & 0.570 & $<0.100$ & $<0.250$ & $<0.250$ & 0.156 & $<0.100$ & $<0.250$ & $<0.250$ & 0.218 \\
\hline Vanadium & 0.026 & $<0.050$ & $<0.050$ & 0.038 & 0.026 & $<0.050$ & $<0.050$ & 0.053 & $<0.020$ & $<0.050$ & $<0.050$ & 0.021 & $<0.020$ & $<0.050$ & $<0.050$ & 0.025 \\
\hline Zinc & 0.042 & 0.133 & 0.169 & 0.421 & 0.06 & 0.47 & 1.302 & 36.41 & 0.010 & $<0.025$ & 0.092 & 0.050 & $<0.010$ & $<0.025$ & $<0.025$ & 0.088 \\
\hline Zirconium & 0.022 & $<0.050$ & $<0.050$ & $<0.020$ & 0.031 & 0.052 & $<0.050$ & $<0.020$ & 0.024 & $<0.050$ & $<0.050$ & $<0.020$ & 0.032 & $<0.050$ & $<0.050$ & $<0.020$ \\
\hline Mercury ${ }^{\circ}$ & 8.55 & 41.3 & $<0.050$ & 5.86 & 38.16 & 54.0 & 20.38 & 10.44 & 8.20 & 7.44 & 52 & 21.0 & 8.62 & 5.86 & 12.83 & 11.57 \\
\hline
\end{tabular}

${ }^{2}$ Results are in micrograms per liter. 
Table B.4. Leaching results (milligrams per liter) for the FERN series

\begin{tabular}{|c|c|c|c|c|c|c|c|c|c|c|c|c|c|c|c|c|c|}
\hline \multirow[b]{2}{*}{ Time } & \multicolumn{4}{|c|}{$\mathrm{pH} 3$} & \multicolumn{5}{|c|}{$\mathrm{pH} 5$} & \multicolumn{4}{|c|}{$\mathrm{pH} 7$} & \multicolumn{4}{|c|}{$\mathrm{pH} 12.5$} \\
\hline & $2 w$ & $1 \mathrm{~m}$ & $2 m$ & $3 m$ & $2 w$ & $1 \mathrm{~m}$ & & $2 m$ & $3 m$ & $2 w$ & $1 \mathrm{~m}$ & $2 m$ & $3 m$ & $2 w$ & $1 \mathrm{~m}$ & $2 m$ & $3 m$ \\
\hline Welght(g) & 8.66 & 15.36 & 15.01 & 16.11 & 10.47 & 27.78 & & 19.33 & 18.80 & 10.70 & 22.07 & 20.40 & 20.36 & 7.72 & 17.53 & 20.94 & 18.28 \\
\hline Inltlal pH & 2.96 & 2.85 & 3.05 & 3.05 & 5.00 & 4.63 & & 4.89 & 4.89 & 7.87 & 7.55 & 8.06 & 8.06 & 12.53 & 12.68 & 12.48 & 12.48 \\
\hline FInal pH & 3.41 & 4.13 & 4.65 & 4.71 & 5.04 & 5.98 & & 7.43 & 7.38 & 9.08 & 9.02 & 9.01 & 7.29 & 12.58 & 12.39 & 10.27 & 9.23 \\
\hline Silver & $<0.005$ & $<0.005$ & $<0.013$ & $<0.005$ & $<0.005$ & $<0.005$ & $<$ & 0.013 & $<0.005$ & $<0.005$ & 0.013 & 0.016 & $<0.005$ & $<0.005$ & 0.013 & 0.027 & $<0.005$ \\
\hline Aluminum & 0.310 & 0.220 & 0.200 & 0.145 & $<0.060$ & $<0.060$ & $<$ & 0.150 & $<0.060$ & 0.201 & 0.160 & 0.189 & $<0.060$ & 0.170 & 0.161 & 0.281 & $<0.060$ \\
\hline Arsenlc & $<0.020$ & $<0.020$ & $<0.050$ & 0.021 & 0.022 & 0.026 & $<$ & 0.050 & 0.023 & $<0.020$ & $<0.020$ & 0.056 & 0.020 & 0.022 & 0.021 & $<0.050$ & 0.027 \\
\hline Boron & $<0.040$ & $<0.040$ & $<0.100$ & 0.158 & $<0.040$ & $<0.040$ & $<$ & 0.100 & $<0.040$ & $<0.040$ & $<0.040$ & $<0.100$ & 0.178 & $<0.040$ & $<0.040$ & $<0.100$ & 0.203 \\
\hline Barium & 0.006 & 0.024 & 0.027 & 0.024 & 0.011 & 0.055 & & 0.037 & 0.031 & 0.008 & 0.022 & 0.033 & 0.030 & 0.022 & 0.036 & 0.039 & 0.047 \\
\hline Berylllum & 0.003 & 0.003 & 0.003 & $<0.001$ & 0.004 & 0.003 & $<$ & 0.003 & $<0.001$ & 0.004 & 0.003 & 0.004 & $<0.001$ & 0.004 & 0.003 & 0.004 & $<0.001$ \\
\hline Calclum & 1261 & 2225 & 2061 & 2151 & 1596 & 3313 & & 2344 & 2207 & 1547 & 3373 & 2876 & 2301 & 2018 & 5070 & 4614 & 4219 \\
\hline Cadmlum & $<0.002$ & $<0.002$ & $<0.005$ & $<0.002$ & $<0.002$ & $<0.002$ & $<$ & 0.005 & $<0.002$ & $<0.002$ & $<0.002$ & $<0.005$ & $<0.002$ & $<0.002$ & $<0.002$ & $<0.005$ & $<0.002$ \\
\hline Chromium & $<0.010$ & 0.019 & $<0.025$ & 0.015 & $<0.010$ & $<0.010$ & $<$ & 0.025 & $<0.010$ & $<0.010$ & $<0.010$ & $<0.025$ & $<0.010$ & 0.010 & $<0.010$ & 0.033 & $<0.010$ \\
\hline Copper & 0.012 & $<0.008$ & 0.025 & $<0.008$ & 0.014 & 0.009 & & 0.030 & $<0.008$ & 0.012 & 0.049 & 0.054 & $<0.008$ & 0.027 & 0.057 & 0.096 & $<0.008$ \\
\hline Iron & 1.51 & 2.35 & 1.62 & 1.98 & 1.863 & 0.980 & $<$ & 0.250 & $<0.100$ & $<0.100$ & $<0.100$ & $<0.250$ & $<0.100$ & $<0.100$ & $<0.100$ & $<0.250$ & $<0.100$ \\
\hline Potassium & 7.48 & 3.28 & 6.94 & 2.68 & 4.56 & 5.94 & & 9.66 & 4.57 & 4.38 & 4.69 & 9.64 & 4.61 & 6.15 & 4.54 & 14.40 & 7.73 \\
\hline Magnesium & 5.23 & 9.59 & 9.30 & 9.93 & 6.73 & 8.28 & & 3.12 & 1.25 & 0.22 & 0.56 & 0.556 & 0.621 & 0.051 & 0.322 & 0.850 & 0.811 \\
\hline Manganese & 0.024 & 0.043 & 0.029 & 0.032 & 0.022 & 0.018 & & 0.024 & $<0.002$ & $<0.002$ & 0.005 & $<0.006$ & $<0.003$ & $<0.002$ & 0.005 & $<0.006$ & $<0.002$ \\
\hline Sodium & 17.42 & 26.48 & 25.58 & 29.11 & 1483 & 1382 & & 1470 & 1316 & 24.2 & 44.2 & 40.0 & 37.37 & 16.6 & 35.1 & 42.7 & 36.18 \\
\hline Nickel & $<0.008$ & 0.008 & $<0.020$ & $<0.008$ & $<0.008$ & $<0.008$ & $<$ & 0.020 & $<0.008$ & $<0.008$ & 0.030 & $<0.022$ & $<0.008$ & $<0.008$ & 0.024 & 0.032 & $<0.008$ \\
\hline Lead & $<0.014$ & $<0.014$ & $<0.035$ & $<0.014$ & $<0.014$ & $<0.014$ & $<$ & 0.035 & $<0.014$ & $<0.014$ & $<0.014$ & $<0.035$ & $<0.014$ & $<0.014$ & $<0.014$ & $<0.035$ & $<0.014$ \\
\hline Selenilum & 0.024 & $<0.020$ & $<0.050$ & $<0.020$ & $<0.020$ & $<0.020$ & $<$ & 0.050 & $<0.020$ & $<0.020$ & $<0.020$ & $<0.050$ & $<0.020$ & $<0.020$ & $<0.020$ & $<0.050$ & $<0.020$ \\
\hline Antimony & $<0.020$ & $<0.020$ & $<0.050$ & $<0.020$ & $<0.020$ & $<0.020$ & $<$ & 0.050 & $<0.020$ & $<0.020$ & 0.057 & $<0.050$ & $<0.020$ & $<0.020$ & 0.047 & 0.054 & $<0.020$ \\
\hline Sillicon & 3.22 & 5.99 & 7.02 & 7.20 & 3.13 & 11.19 & & 8.40 & 7.09 & 4.45 & 5.71 & 8.89 & 7.90 & 1.11 & 2.33 & 4.46 & 5.30 \\
\hline Strontlum & 0.431 & 0.874 & 0.615 & 0.869 & 0.591 & 1.531 & & 0.784 & 0.913 & 0.564 & 1.355 & 0.920 & 0.989 & 1.26 & 2.69 & 2.08 & 2.23 \\
\hline Thorlum & $<0.260$ & $<0.260$ & $<0.650$ & 0.408 & $<0.260$ & $<0.260$ & $<$ & 0.650 & 0.281 & $<0.260$ & $<0.260$ & $<0.650$ & 0.382 & $<0.260$ & $<0.260$ & $<0.650$ & 0.629 \\
\hline Titanium & 0.007 & 0.012 & 0.014 & $<0.002$ & 0.009 & 0.017 & & 0.014 & $<0.002$ & 0.008 & 0.013 & 0.014 & $<0.002$ & 0.011 & 0.024 & 0.019 & $<0.002$ \\
\hline Thallium & $<0.016$ & $<0.016$ & $<0.040$ & $<0.016$ & $<0.016$ & $<0.016$ & & 0.049 & $<0.016$ & $<0.016$ & $<0.016$ & 0.114 & 0.017 & $<0.016$ & $<0.016$ & 0.127 & 0.028 \\
\hline Uranium & $<0.100$ & 0.113 & 0.337 & 0.265 & $<0.100$ & 0.121 & & 0.277 & 0.288 & $<0.100$ & $<0.100$ & $<0.250$ & 0.303 & $<0.100$ & $<0.100$ & $<0.250$ & 0.488 \\
\hline Vanadlum & 0.020 & 0.027 & $<0.050$ & 0.020 & $<0.020$ & $<0.020$ & $<$ & 0.050 & $<0.020$ & $<0.020$ & 0.172 & 0.092 & $<0.020$ & $<0.020$ & 0.139 & 0.193 & $<0.020$ \\
\hline Zlnc & 0.023 & 0.012 & 0.260 & 0.036 & 0.01 & $<0.01$ & & 0.060 & 0.011 & $<0.010$ & $<0.010$ & 0.046 & 0.014 & $<0.010$ & $<0.010$ & 0.038 & $<0.010$ \\
\hline Zirconlum & 0.026 & 0.042 & $<0.050$ & $<0.020$ & 0.025 & 0.040 & & 0.056 & $<0.020$ & 0.026 & 0.220 & 0.082 & $<0.020$ & $<0.020$ & 0.154 & 0.204 & $<0.020$ \\
\hline Mercury & 12.33 & 4.47 & 5.03 & 80.2 & 10.07 & 28.3 & & 125 & 184 & 15.7 & 73.0 & 200 & 107.8 & 15.1 & 42.0 & 1223 & 264 \\
\hline
\end{tabular}

${ }^{\mathrm{a}}$ Results are in micrograms per liter. 
Table B.5. Leaching results (milligrams per liter) for the OR series

\begin{tabular}{|c|c|c|c|c|c|c|c|c|c|c|c|c|c|c|c|c|}
\hline \multirow[b]{2}{*}{ Time } & \multicolumn{4}{|c|}{$\mathrm{pH} 3$} & \multicolumn{4}{|c|}{$\mathrm{pH} 5$} & \multicolumn{4}{|c|}{$\mathrm{pH} 7$} & \multicolumn{4}{|c|}{$\mathrm{pH} 12.5$} \\
\hline & $2 w$ & $1 \mathrm{~m}$ & $2 m$ & $3 m$ & $2 w$ & $1 \mathrm{~m}$ & $2 m$ & $3 m$ & $2 w$ & $1 \mathrm{~m}$ & $2 m$ & $3 m$ & $2 w$ & $1 \mathrm{~m}$ & $2 m$ & $3 m$ \\
\hline Weight(g) & 24.25 & 4.66 & 11.39 & 9.55 & 30.68 & 8.76 & 8.47 & 9.74 & 17.60 & 5.46 & 8.10 & 8.99 & 16.32 & 6.64 & 8.32 & 12.27 \\
\hline Inilial pH & 2.96 & 2.85 & 3.05 & 3.05 & 5.00 & 4.63 & 4.89 & 4.89 & 7.87 & 7.55 & 8.06 & 8.06 & 12.53 & 12.53 & 12.48 & 12.48 \\
\hline Final pH & 5.83 & 5.20 & 6.31 & 6.54 & 7.59 & 5.49 & 6.80 & 7.30 & 10.50 & 10.36 & 10.71 & $\begin{array}{c}10.69 \\
\therefore\end{array}$ & 12.52 & 12.22 & 12.25 & 12.03 \\
\hline Silver & $<0.005$ & $<0.013$ & $<0.013$ & $<0.005$ & $<0.005$ & $<0.013$ & $<0.013$ & $<0.005$ & $<0.005$ & $<0.013$ & $<0.013$ & $<0.005$ & $<0.005$ & $<0.013$ & $<0.013$ & 0.006 \\
\hline Aluminum & 0.203 & 0.520 & 0.270 & $<0.060$ & $<0.060$ & 0.219 & $<0.150$ & $<0.060$ & 0.155 & 0.362 & 0.271 & $<0.060$ & 0.181 & 0.366 & 0.232 & $<0.060$ \\
\hline Arsenic & $<0.020$ & $<0.050$ & $<0.050$ & $<0.020$ & $<0.020$ & $<0.050$ & $<0.050$ & $<0.020$ & $<0.020$ & $<0.050$ & $<0.050$ & $<0.020$ & $<0.020$ & $<0.050$ & $<0.050$ & $<0.020$ \\
\hline Boron & 0.258 & 0.188 & 0.293 & 0.432 & $<0.040$ & $<0.100$ & $<0.100$ & $<0.040$ & 0.116 & 0.105 & 0.149 & 0.291 & 0.407 & 0.205 & 0.280 & 0.468 \\
\hline Barlum & $<0.002$ & $<0.005$ & $<0.005$ & 0.004 & 0.004 & $<0.005$ & $<0.005$ & 0.004 & $<0.002$ & $<0.005$ & $<0.005$ & $<0.002$ & 0.016 & 0.010 & 0.016 & 0.015 \\
\hline Beryllium & 0.004 & 0.006 & 0.007 & $<0.001$ & 0.004 & 0.007 & 0.008 & $<0.001$ & 0.004 & 0.007 & 0.009 & $<0.001$ & 0.004 & 0.007 & 0.007 & $<0.001$ \\
\hline Calclum & 8.36 & 3.26 & 5.63 & 4.91 & 9.79 & 5.37 & 4.70 & 4.48 & 3.23 & 1.29 & 1.40 & 1.13 & 989 & 568 & 588 & 561 \\
\hline Cadn & $<0.002$ & $<0.005$ & $<0.005$ & $<0.002$ & $<0.002$ & $<0.005$ & $<0.005$ & $<0.002$ & $\mid<0.002$ & $<0.005$ & $<0.005$ & $<0.002$ & $<0.002$ & $<0.005$ & $<0.005$ & $<0.002$ \\
\hline Chromium & $<0.010$ & 0.039 & $<0.025$ & $<0.010$ & $<0.010$ & $<0.025$ & $<0.025$ & $<0.010$ & $<0.010$ & $<0.025$ & $<0.025$ & $<0.010$ & 0.010 & $<0.025$ & $<0.025$ & $<0.010$ \\
\hline Copper & $<0.008$ & $<0.020$ & $<0.020$ & $<0.008$ & $<0.008$ & $<0.020$ & $<0.020$ & $<0.008$ & $<0.008$ & $<0.020$ & $<0.020$ & 0.009 & 0.008 & $<0.020$ & 0.021 & $<0.008$ \\
\hline Iron & 1.206 & $<0.250$ & $<0.250$ & 0.636 & 0.185 & $<0.250$ & $<0.250$ & 0.123 & $<0.100$ & $<0.250$ & $<0.250$ & $<0.100$ & $<0.100$ & $<0.250$ & $<0.250$ & $<0.100$ \\
\hline Pota & 6.65 & 1.81 & 7.01 & 4.83 & 9.25 & 2.30 & 7.53 & 3.05 & 5.20 & 1.30 & 8.78 & 9.79 & 7.42 & 2.32 & 12.88 & 4.55 \\
\hline Magnesium & 1049 & 414 & 817 & 915 & 468 & 509 & 391 & 471 & 52.03 & 21.82 & 16.49 & 13.88 & 0.051 & 0.107 & $<0.100$ & 0.079 \\
\hline Manganese & 0.060 & 0.061 & 0.174 & 0.069 & 0.005 & 0.025 & 0.121 & 0.003 & $<0.002$ & $<0.006$ & 0.117 & $<0.002$ & $<0.002$ & $<0.006$ & 0.116 & $<0.002$ \\
\hline Sodium & 483 & 138 & 223 & 238 & 1954 & 1589 & 1477 & 1464 & 323 & 100 & 155 & 173 & 312 & 123 & 168 & 233 \\
\hline Nickel & $<0.008$ & $<0.020$ & $<0.020$ & $<0.008$ & $<0.008$ & $<0.020$ & $<0.020$ & $<0.008$ & $<0.008$ & $<0.020$ & $<0.020$ & $<0.008$ & $<0.008$ & $<0.020$ & $<0.020$ & $<0.008$ \\
\hline Lead & $<0.014$ & $<0.035$ & $<0.035$ & $<0.014$ & $<0.014$ & $<0.035$ & $<0.035$ & $<0.014$ & $<0.014$ & $<0.035$ & $<0.035$ & $<0.014$ & $<0.014$ & $<0.035$ & $<0.035$ & $<0.014$ \\
\hline Selenium & $<0.020$ & $<0.050$ & $<0.050$ & 0.021 & $<0.020$ & $<0.050$ & $<0.050$ & $<0.020$ & $<0.023$ & $<0.050$ & $<0.050$ & $<0.020$ & $<0.020$ & $<0.050$ & $<0.050$ & $<0.020$ \\
\hline Antimony & $<0.020$ & $<0.050$ & $<0.050$ & 0.021 & $<0.020$ & $<0.050$ & $<0.050$ & $<0.020$ & $<0.020$ & $<0.050$ & $<0.050$ & $<0.020$ & $<0.020$ & $<0.050$ & $<0.050$ & $<0.020$ \\
\hline Silicon & 1.265 & 1.084 & 0.692 & 0.294 & 0.893 & 0.794 & 0.446 & 0.423 & 0.748 & 0.728 & 0.397 & 0.326 & 2.086 & 1.214 & 0.966 & 0.582 \\
\hline Strontlum & 0.023 & 0.008 & 0.016 & 0.014 & 0.029 & 0.014 & 0.014 & 0.013 & 0.008 & $<0.005$ & 0.005 & 0.003 & 0.796 & 0.453 & 0.665 & 0.742 \\
\hline Thorium & $<0.260$ & $<0.650$ & $<0.650$ & $<0.260$ & $<0.260$ & $<0.650$ & $<0.650$ & $<0.260$ & $<0.260$ & $<0.650$ & $<0.650$ & $<0.260$ & $<0.260$ & $<0.650$ & $<0.650$ & $<0.260$ \\
\hline Titanium & $<0.002$ & $<0.005$ & $<0.005$ & $<0.002$ & $<0.002$ & $<0.005$ & $<0.005$ & $<0.002$ & $<0.002$ & $<0.005$ & $<0.005$ & $<0.002$ & 0.005 & 0.005 & $<0.005$ & $<0.002$ \\
\hline Thallium & $<0.016$ & $<0.040$ & $<0.040$ & $<0.016$ & $<0.016$ & $<0.040$ & $<0.040$ & $<0.016$ & $<0.016$ & $<0.040$ & $<0.040$ & $<0.016$ & $<0.016$ & $<0.040$ & $<0.040$ & $<0.016$ \\
\hline Uranium & $<0.100$ & $<0.250$ & $<0.250$ & 0.102 & $<0.100$ & $<0.250$ & $<0.250$ & $<0.100$ & $<0.100$ & $<0.250$ & $<0.250$ & $<0.100$ & $<0.100$ & $<0.250$ & $<0.250$ & 0.112 \\
\hline Vanadium & $<0.020$ & $<0.050$ & $<0.050$ & $<0.020$ & $<0.020$ & $<0.050$ & $<0.050$ & $<0.020$ & $<0.020$ & $<0.050$ & $<0.050$ & $<0.020$ & $<0.020$ & $<0.050$ & $<0.054$ & $<0.020$ \\
\hline Zinc & 156 & 276 & 200 & 110 & 75.1 & 168.2 & 67.1 & 33.4 & 0.116 & 0.345 & 0.185 & 0.138 & 2.77 & 1.70 & 1.59 & 0.97 \\
\hline Zirconium & 0.140 & 0.246 & 0.186 & $<0.020$ & 0.089 & 0.168 & 0.072 & $<0.020$ & $<0.020$ & $<0.050$ & $<0.050$ & $<0.020$ & $<0.021$ & $<0.050$ & $<0.050$ & $<0.020$ \\
\hline Mercury & 16.0 & 76 & 4.47 & 62.5 & 12.9 & 108.5 & 34.3 & 213 & 4.46 & 21.5 & $<0.050$ & 7.25 & 52.5 & 81.2 & 14.23 & 24.2 \\
\hline
\end{tabular}

${ }^{\mathrm{a}}$ Results are in micrograms per liter. 
Table B.6. Leaching results (milligrams per liter) for the $\mathrm{DD}$ series

\begin{tabular}{|c|c|c|c|c|c|c|c|c|c|c|c|c|c|c|c|c|c|c|c|}
\hline \multirow[b]{2}{*}{ Time } & \multicolumn{5}{|c|}{$\mathrm{pH} 3$} & \multicolumn{5}{|c|}{$\mathrm{pH} 5$} & \multicolumn{5}{|c|}{$\mathrm{pH} 7$} & \multicolumn{4}{|c|}{$\mathrm{pH} 12.5$} \\
\hline & & $2 w$ & $1 \mathrm{~m}$ & $2 m$ & $3 m$ & $2 w$ & $1 \mathrm{~m}$ & & $2 m$ & $3 \mathrm{~m}$ & $2 w$ & & $1 \mathrm{~m}$ & $2 m$ & $3 m$ & $2 w$ & $1 \mathrm{~m}$ & $2 m$ & $3 m$ \\
\hline Weight(g) & & 7.00 & 5.37 & 5.38 & 6.07 & 7.13 & 5.65 & & 6.22 & 4.90 & 5.41 & & 4.95 & 15.28 & 7.51 & 5.50 & 5.21 & 4.77 & 5.75 \\
\hline Inllial pH & & 2.96 & 2.85 & 2.92 & 2.92 & 5.00 & 4.63 & & 4.72 & 4.80 & 7.87 & & 7.55 & 8.06 & 8.06 & 12.53 & 12.53 & 12.61 & 12.61 \\
\hline Final pH & & 4.84 & 6.02 & 5.68 & 8.75 & 7.32 & 5.54 & & 7.56 & 7.59 & 10.51 & & 10.35 & 10.64 & 10.74 & 12.41 & 12.19 & 12.72 & 12.64 \\
\hline Silver & $<$ & 0.005 & $<0.005$ & $<0.013$ & $<0.005$ & $<0.005$ & $<0.005$ & $<$ & 0.013 & $<0.005$ & $<0.005$ & $<$ & 0.005 & $<0.013$ & $<0.005$ & $<0.005$ & $<0.005$ & 0.028 & $<0.005$ \\
\hline Aluminum & & 0.185 & 0.107 & 0.199 & $<0.060$ & $<0.060$ & $<0.060$ & $<$ & 0.150 & $<0.060$ & 0.110 & & 0.080 & $<0.150$ & 0.092 & 0.122 & 0.063 & 0.152 & $<0.060$ \\
\hline Arsenic & $<$ & 0.020 & $<0.020$ & $<0.050$ & $<0.020$ & $<0.020$ & $<0.020$ & $<$ & 0.050 & $<0.020$ & $<0.020$ & $<$ & 0.020 & $<0.050$ & $<0.020$ & $<0.020$ & $<0.020$ & $<0.050$ & $<0.020$ \\
\hline Boron & & 0.377 & 0.900 & 0.688 & 0.971 & $<0.040$ & 0.056 & & 0.166 & 0.183 & 0.363 & & 0.719 & 1.033 & 1.228 & 1.46 & 1.33 & 1.58 & 1.56 \\
\hline Barlum & & 0.017 & 0.026 & 0.026 & 0.035 & 0.017 & 0.021 & & 0.026 & 0.026 & 0.010 & & 0.012 & 0.015 & 0.017 & 0.027 & 0.034 & 0.053 & 0.054 \\
\hline Beryllium & & 0.003 & 0.003 & 0.004 & $<0.001$ & 0.003 & 0.003 & & 0.003 & $<0.001$ & 0.003 & & 0.003 & 0.005 & $<0.001$ & 0.003 & 0.003 & 0.003 & $<0.001$ \\
\hline Calclum & & 13.31 & 16.49 & 14.86 & 13.21 & 10.47 & 14.51 & & 15.25 & 12.73 & 4.39 & & 4.71 & 7.68 & 4.18 & 709 & 540 & 1057 & 1048 \\
\hline Cadmium & $<$ & 0.002 & $<0.002$ & $<0.005$ & $<0.002$ & $<0.002$ & $<0.002$ & $<$ & 0.005 & $<0.002$ & $<0.002$ & $<$ & 0.002 & $<0.005$ & $<0.002$ & $<0.002$ & $<0.002$ & $<0.005$ & $<0.002$ \\
\hline Chromlum & $<$ & 0.010 & $<0.010$ & $<0.025$ & $<0.010$ & $<0.010$ & $<0.010$ & $<$ & 0.025 & $<0.010$ & $<0.010$ & $<$ & 0.010 & $<0.025$ & $<0.010$ & $<0.010$ & $<0.010$ & $<0.025$ & $<0.010$ \\
\hline Copper & $<$ & 0.008 & $<0.008$ & $<0.020$ & $<0.008$ & $<0.008$ & $<0.008$ & $<$ & 0.020 & $<0.008$ & $<0.008$ & $<$ & 0.008 & $<0.020$ & $<0.008$ & 0.037 & $<0.008$ & $<0.020$ & $<0.008$ \\
\hline Iron & & 0.618 & 1.282 & 0.366 & 0.622 & $<0.100$ & 0.258 & $<$ & 0.250 & 0.107 & $<0.100$ & $<$ & 0.100 & $<0.250$ & $<0.100$ & $<0.100$ & $<0.100$ & $<0.250$ & $<0.100$ \\
\hline Potasslum & & 8.61 & 4.15 & 8.42 & 5.40 & 12.33 & 4.224 & & 7.14 & 4.24 & 8.24 & & 2.87 & 9.61 & 11.7 & 8.32 & 4.41 & 7.49 & 4.39 \\
\hline Magneslum & & 766 & 1229 & 1083 & 1346 & 381 & 536 & & 587 & 524 & 25.6 & & 21.3 & 35.1 & 16.6 & 0.094 & 0.107 & 0.117 & 0.108 \\
\hline Manganese & & 0.026 & 0.050 & 0.152 & 0.004 & 0.008 & 0.008 & & 0.116 & $<0.002$ & $<0.002$ & $<$ & 0.002 & 0.109 & $<0.002$ & $<0.002$ & $<0.002$ & 0.112 & $<0.002$ \\
\hline Sodlum & & 828 & 683 & 634 & 614 & 1976 & 1845 & & 2079 & 1606 & 646 & & 561 & 1866 & 960 & 640 & 491 & 524 & 602 \\
\hline Nickel & $<$ & 0.008 & $<0.008$ & $<0.020$ & $<0.008$ & $<0.008$ & $<0.008$ & $<$ & 0.020 & $<0.008$ & $<0.008$ & $<$ & 0.008 & $<0.020$ & $<0.008$ & $<0.008$ & $<0.008$ & $<0.020$ & $<0.008$ \\
\hline Lead & $<$ & 0.014 & $<0.014$ & $<0.035$ & $<0.014$ & $<0.014$ & $<0.014$ & $<$ & 0.035 & $<0.014$ & $<0.014$ & $<$ & 0.014 & $<0.035$ & $<0.014$ & $<0.014$ & $<0.014$ & $<0.035$ & $<0.014$ \\
\hline Selenium & $<$ & 0.020 & $<0.020$ & $<0.050$ & 0.021 & $<0.020$ & $<0.020$ & $<$ & 0.050 & $<0.020$ & $<0.020$ & $<$ & 0.020 & $<0.050$ & $<0.020$ & $<0.020$ & $<0.020$ & $<0.050$ & $<0.020$ \\
\hline Antimony & $<$ & 0.020 & $<0.020$ & $<0.050$ & 0.022 & $<0.020$ & $<0.020$ & $<$ & 0.050 & $<0.020$ & $<0.020$ & $<$ & 0.020 & $<0.050$ & $<0.020$ & $<0.020$ & $<0.020$ & $<0.050$ & $<0.020$ \\
\hline Sillicon & & 1.417 & 1.754 & 1.001 & 0.449 & 1.138 & 1.155 & & 0.745 & 0.342 & 0.921 & & 0.873 & 0.896 & 0.646 & 1.132 & 1.112 & 1.637 & 0.732 \\
\hline Strontlum & & 0.061 & 0.067 & 0.061 & 0.045 & 0.048 & 0.060 & & 0.070 & 0.051 & 0.025 & & 0.026 & 0.058 & 0.027 & 0.701 & 0.571 & 0.810 & 0.655 \\
\hline Thorlum & $<$ & 0.260 & $<0.260$ & $<0.650$ & $<0.260$ & $<0.260$ & $<0.260$ & $<$ & 0.650 & $<0.260$ & $<0.260$ & $<$ & 0.260 & $<0.650$ & $<0.260$ & $<0.260$ & $<0.260$ & $<0.650$ & $<0.260$ \\
\hline Tltanlum & & 0.002 & 0.002 & $<0.005$ & $<0.002$ & $<0.002$ & $<0.002$ & $<$ & 0.005 & $<0.002$ & $<0.002$ & $<$ & 0.002 & $<0.005$ & $<0.002$ & 0.004 & 0.003 & $<0.005$ & $<0.002$ \\
\hline Thalllum & $<$ & 0.016 & $<0.016$ & $<0.040$ & $<0.016$ & $<0.016$ & $<0.016$ & $<$ & 0.040 & $<0.016$ & $<0.016$ & $<$ & 0.016 & $<0.040$ & $<0.016$ & $<0.016$ & $<0.016$ & $<0.040$ & $<0.016$ \\
\hline Uranium & $<$ & 0.100 & $<0.100$ & $<0.250$ & $<0.100$ & $<0.100$ & $<0.100$ & $<$ & 0.250 & $<0.100$ & $<0.100$ & $<$ & 0.100 & $<0.250$ & $<0.100$ & $<0.100$ & $<0.100$ & $<0.250$ & $<0.100$ \\
\hline Vanadium & $<$ & 0.020 & $<0.020$ & $<0.050$ & $<0.027$ & $<0.020$ & $<0.020$ & $<$ & 0.050 & $<0.020$ & $<0.020$ & $<$ & 0.020 & $<0.050$ & 0.026 & $<0.020$ & 0.021 & $<0.050$ & 0.020 \\
\hline Zinc & & 132.9 & 101.7 & 212.3 & 12.6 & 72.42 & 70.48 & & 58.02 & 36.4 & 0.063 & & 0.112 & 0.129 & 0.107 & 4.03 & 1.34 & 2.31 & 2.27 \\
\hline Zirconlum & & 0.121 & 0.112 & 0.189 & 0.05 & 0.078 & 0.084 & & 0.078 & 0.039 & $<0.020$ & $<$ & 0.020 & $<0.050$ & 0.058 & $<0.020$ & 0.028 & 0.052 & 0.021 \\
\hline Mercury & & 210 & 192 & 293 & 8.2 & 65.0 & 133 & & 80.0 & 288 & 13.4 & & 10.6 & $<0.050$ & 9.38 & 33.1 & 70.2 & 406 & 110 \\
\hline
\end{tabular}

${ }^{\text {a }}$ Results are in micrograms per liter. 
ORNL/TM-13728

\section{INTERNAL DISTRIBUTION}

\author{
1. T. B. Conley \\ 2. J. Devore \\ 3. R. M. Harrington \\ 4. C. M. Kendrick \\ 5. P. Kirk \\ 6. K. T. Klasson \\ 7-11. C. H. Mattus
}

\author{
12. M. I. Morris \\ 13. T. E. Myrick \\ 14. S. M. Robinson \\ 15. R. D. Spence \\ 16. Central Research Library \\ 17. Laboratory Records - RC \\ 18-19. Laboratory Records - for \\ submission to OSTI
}

\section{EXTERNAL DISTRIBUTION}

20. John Austin, U.S. EPA, OSW/5302W, 401 M Street, Washington, DC 20460

21. Heather Holmes-Burns, Westinghouse Savannah River Company, P.O. Box 616, 72421E, Aiken, South Carolina 29862

22. Mary Cunningham, U.S. EPA, OSW/5302W, $401 \mathrm{M}$ Street, Washington, DC 20460

23. Ron Fontana, DOE-Idaho Operations, 850 Energy Drive, Idaho Falls, Idaho 83401-1235

24. G. A. Hulet, Idaho National Engineering and Environmental Laboratory, 2525 N. Freemont, Idaho Falls, Idaho 83415-3875

25. D. A. Hutchins, U.S. DOE, 55 Jefferson Avenue, MS-EW97, Oak Ridge, Tennessee 37830

26. Norm Jacobs, Nuclear Fuel Services, 1205 Banner Hill Road, Erwin, Tennessee 37650

27. David S. Kosson, Rutgers University, Department of Chemical and Biochemical Engineering, 98 Brett Road, Engineering Bldg., C-258, Piscataway, New Jersey 98854-8058

28. Josh Lewis, U.S. EPA, OSW/5302W, $401 \mathrm{M}$ Street, Washington, DC 20460

29. Cavanaugh Mims, U.S. DOE, 55 Jefferson Avenue, MS-EW-97, Oak Ridge, Tennessee 37830

30. Bill Owca, DOE-Idaho Operations, 2525 N. Freemont, Idaho Falls, Idaho 83415-3875

31. Lynn Schwendiman, DOE-Idaho Operations, 2525 N. Freemont, Idaho Falls, Idaho 83415-8102

32. Robin M. Stewart, ADA Technologies, Inc., 304 Inverness Way South, Suite 365, Englewood, Colorado 80112

33. R. Eric Williams, Idaho National Engineering and Environmental Laboratory, $2525 \mathrm{~N}$. Freemont, Idaho Falls, Idaho 83415-3875 